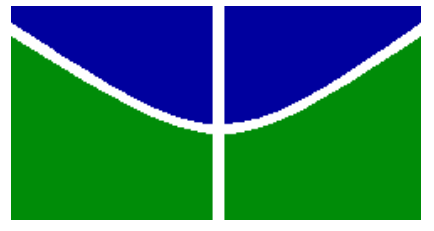

UNIVERSIDADE DE BRASÍLIA - UnB

Programa de Pós-Graduação em

Nanociência e Nanobiotecnologia

MARCELO DE SOUZA PARISE

ELABORAÇÃO DE FLUIDOS MAGNÉTICOS À BASE DE GLICONANOPARTÍCULAS MAGNÉTICAS DE $\mathrm{Mn}_{1-x} \mathrm{Co}_{x} \mathrm{Fe}_{2} \mathrm{O}_{4}$ FUNCIONALIZADAS COM ÁCIDOS CARBOXÍLICOS POLIHIDROXILADOS, VISANDO APLICAÇÕES EM NANOBIOTECNOLOGIA 
Universidade de Brasília

Instituto de Ciências Biológicas

Programa de Pós-Graduação em Nanociência e Nanobiotecnologia

MARCELO DE SOUZA PARISE

ELABORAÇÃO DE FLUIDOS MAGNÉTICOS À BASE DE GLICONANOPARTÍCULAS MAGNÉTICAS DE $\mathrm{Mn}_{1-x} \mathrm{Co}_{x} \mathrm{Fe}_{2} \mathrm{O}_{4}$ FUNCIONALIZADAS COM ÁCIDOS CARBOXÍLICOS POLIHIDROXILADOS, VISANDO APLICAÇÕES EM NANOBIOTECNOLOGIA

Dissertação apresentada ao programa de Pós-Graduação em Nanociências e Nanobiotecnologia, do Instituto de Ciências Biológicas da Universidade de Brasília, como parte integrante dos requisitos para obtenção do Título de Mestre em Nanociências e Nanobiotecnologia.

Orientador: Prof ${ }^{\circ}$. Dr. Marcelo Henrique Sousa

BRASÍLIA - DF 
Dissertação de Mestrado

Marcelo de Souza Parise

Título:

\section{"Elaboração de fluidos magnéticos à base de gliconanopartículas magnéticas de Mn1-xCoxFe2O4 funcionalizadas com ácidos carboxílicos polihidroxilados, visando aplicações em nanobiotecnologia."}

Comissão Examinadora:

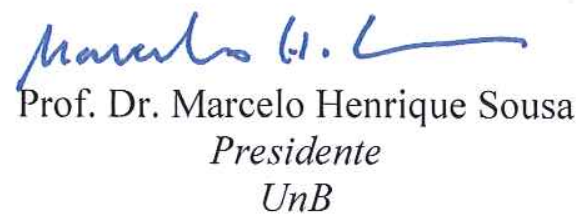

Prof. Dr. Paulo Cesar de Morais Membro Titular Interno Vinculado ao Programa $U n B$

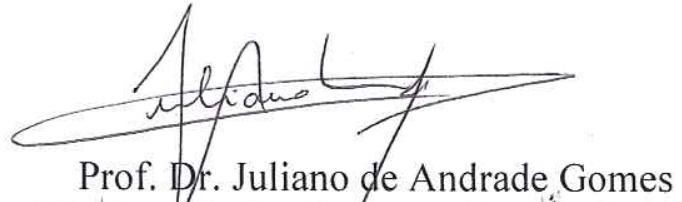
Membro Titular Externo não vinculado ao programa PCDF 
Dedico esse trabalho as três luzes da minha vida acadêmica:

JOSÉ AMÉRICO VERÇOSA

KALIL SKEF NETO

KARL EBERARD BESSLER 


\section{AGRADECIMENTOS}

Agradecerei a mim!!

Não o farei com nomes próprios, agradecerei a mim porque mereço esse agradecimento. Eu e minhas limitações permitiremos agradecer-me. Sou grato a mim por conhecer toda a amplitude da minha ignorância.

Assim, espero que aqui entenda-se que esse agradecimento nada mais significa que o meu reconhecimento a todas as pessoas que souberam me suportar.

Agradeço a mim por cumprir os castigos que meus genitores me impuseram, sem eles eu não estaria na Terra e nem seria quem sou.

Agradeço a mim, por saber que meus irmãos e a minha família me fizeram sempre presente em suas vidas, mesmo sendo quem sou. Agradeço a mim por entender que meus sogros são pessoas partícipes do meu crescimento, mesmo conhecendo minha truculência me agraciaram com o que tenho de mais precioso; o meu Amor e seus frutos. Eu amo vocês e, por incrível que pareça, vocês me amam!!!

Agradeço a mim por ter conseguido estudar na minha querida e judiada Universidade de Brasília, ainda que soubesse das minhas limitações. E como esquecer de agradecer-me por passar alguns anos no Instituto de Química da UnB? Os docentes apresentaram-se resignados com a minha presença por lá. Agradeço-me, também, por ser integrante do Instituto de Física; todos muito colaboraram na minha formação profissional. O meu obrigado sincero, e reflexivo, estende-se para o chefe que nunca imaginei ter, que, com sabedoria ímpar, muito colaborou para que eu aqui chegasse. 0 meu amigo e orientador, que tanto conheço, pequeno e talentoso, em verdade é um gigante forte e um químico genial, que muito perseverou e consentiu em ser meu orientador, sou muito agradecido por isso. Aos meus colegas de estudo, das terras do Sol Nascente à terra Brasilis, todos sempre com muita paciência e companheirismo diziam sempre para que eu não esquecesse que ainda sou um aluno; e eu me agradeço por ser amigo de vocês.

Para finalizar, e também demonstrar um pouco de incoerência, agradecer-meei por acreditar no Poder Maior, citando aqui um único nome; o do Grande Arquiteto do Universo, sem o qual minha matéria não seria. 


\section{RESUMO}

Nesse trabalho, gliconanopartículas magnéticas, à base de ferrita mista de cobalto e manganês e funcionalizadas com ácido glicérico e ácido glucônico, foram sintetizadas, visando aplicações nanobiotecnológicas. As nanopartículas de óxido magnético foram sintetizadas por coprecipitação alcalina e, após tratamento de superfície, foram peptizadas em meio ácido. Então, condições ótimas de concentração e pH foram estabelecidas para uma máxima funcionalização dos nanogrãos. Após o recobrimento, as nanopartículas foram redispersas em solução aquosa ou glicerol. A estrutura espinélio foi confirmada por experimentos de DRX e dosagens químicas levaram à fórmula química $\mathrm{Mn}_{0,5} \mathrm{Co}_{0,5} \mathrm{Fe}_{2} \mathrm{O}_{4}$ para o material sintetizado. Por MET, nanopartículas com morfologia do tipo esférica e com diâmetro médio de $\sim 17 \mathrm{~nm}$ (e 0,35 de polidispersão) foram encontradas. Esses resultados foram cruzados com os do refinamento de Rietveld dos dados de DRX, confirmando tamanho e estrutura. O sucesso da funcionalização foi verificado por FTIR e medidas de potencial zeta, que mostraram a modificação da superfície, após a complexação da superfície pelos ligantes. No modelo proposto, os grupos carboxila dos ácidos glucônico e glicérico se ligam aos sítios superficiais, enquanto as terminações hidroxila ficam livres para interagir com o solvente. Isso ficou mais bem evidenciado por testes qualitativos de estabilidade coloidal das nanopartículas em diferentes solventes, incluindo glicerol. Medidas de magnetização mostraram um comportamento ferromagnético para as nanopartículas e características superparamagnéticas para os fluidos magnéticos preparados. Além disso, um método eficiente, com base em medidas de densidade, foi proposto para se determinar a concentração dos sois.

Palavras-chave: gliconanopartículas, nanopartículas magnéticas, funcionalização, ácido glicérico, ácido glucônico, nanobiotecnologia 
In this work, magnetic glyconanoparticles, based on cobalt and manganese mixed ferrites, functionalized with glyceric and gluconic acid, were synthesized in view of nanobiotechnological applications. The magnetic oxide nanoparticles were synthesized using alkaline coprecipitation route and, after a surface treatment, were peptized in acidic medium. Thus, optimal conditions of ligand concentration and $\mathrm{pH}$ were set up to a maximal nanograin functionalization. After capping, nanoparticles were redispersed into aqueous solution or glycerol. Spinel structure was confirmed for nanoparticles by XRD experiments and chemical dosages led to chemical formula $\mathrm{Mn}_{0.5} \mathrm{Co}_{0.5} \mathrm{Fe}_{2} \mathrm{O}_{4}$. By TEM, spherical-like morphology and $\sim 17 \mathrm{~nm}$ sized ( 0.35 of polydispersity index) nanostructures were found. These results were well fitted by Rietveld refinement of XRD data, confirming size and structure. The success of functionalization was verified by FTIR and zeta potential which showed the nanoparticle surface modification after ligand complexation. In the proposed model, carboxyl groups of glyceric and gluconic acids were attached to the superficial sites while hydroxyl terminations were free to interact with solvent. This was clearly evidenced by quantitative tests of colloidal stability of nanoparticles in different solvents, including glycerol. Magnetization measurements showed a ferromagnetic behavior of nanoparticles and superparamagnetic features of prepared magnetic fluids. Moreover, an effective method, based on density measurements, was proposed to determine sol concentrations.

Keywords: glyconanoparticles, magnetic nanoparticles, functionalization, glyceric acid, gluconic acid, nanobiotechnology 


\section{LISTA DE FIGURAS}

Figura 1 - Esquematização dos modelos de estabilização coloidal: em água, as NPs podem ser dispersas pela adsorção de cargas elétricas, por ionização de sítios superficiais (cargas positivas em amarelo) ou pela adsorção e ionização de moléculas polifuncionais (estruturas azuis carregadas negativamente). Podem ser peptizadas em solventes apolares, por simples surfactação - e em solventes polares, por dupla surfactação - com tensoativos (estruturas em vermelho e lilás).

Figura 2 - Modelos de funcionalização de nanopartículas magnéticas (NPM) a) núcleo-casca (core-shell), b) sistema maciço polinucleado e c) encapsulamento.

Figura 3 - Representação da cela unitária da estrutura espinélio: as esferas verdes simbolizam os átomos de oxigênio, as vermelhas simbolizam os cátions nos sítios tetraédricos e as amarelas representam os cátions posicionados nos sítios octaédricos.

Figura 4 - Comportamento de dipolos magnéticos, simbolizados pela setas escuras, na presença e ausência de campo magnético externo aplicado. Com base no alinhamento desses dipolos magnéticos, os materiais são classificados como diamagnético, paramagnético, ferromagnético, ferrimagnético e antiferromagnético.

Figura 5 - Comportamento magnético sob a influência de um campo magnético. As curvas de magnetização (magnetização $\times$ campo magnético) para os diferentes tipos de materiais são plotadas no gráfico. Os valores de magnetização de saturação $(M s)$ magnetização remanente $(M r)$ e de campo coercitivo $(H c)$ são destacados na figura.

Figura 6 - Modelos de relaxação do momento magnético em um FM: na relaxação browniana a NPM gira em conjunto com o momento magnético do monodomínio. Na relaxação de Néel, o momento magnético gira dentro da estrutura do monodomínio.

Figura 7 - Quadro com as estruturas dos ácidos carboxílicos polihidroxilados, ácido glicérico e ácido glucônico e de polímeros polihidroxilados polietilenoglicol e dextran.

Figura 8 - Modelo de adsorção do ácido glucônico na superfície das NPMs .

Figura 9 - NPMs de magnetita funcionalizadas com ácido glucônico e glucose

Figura 10 - Viabilidade celular relativa em função da concentração de gliconanopartículas magnéticas com diferentes moléculas funcionalizantes.

Figura 11 - Modelos de adsorção do ácido glucônico na superfície das NPMs em diferentes pHs. As regiões hidrofílicas e metalofílicas são destacados.

Figura 12 - Modelo de lipases magnéticas elaboradas a partir da adsorção de ácido glucônico à superfície das NPMs e ligação das moléculas de lipase aos grupos hidroxílicos superficiais via cabodiimida - EDAC.

Figura 13 - esquema, destacando as principais etapas de preparação e da caracterização das amostras de fluidos magnéticos e nanopartículas utilizados nesse trabalho.

Figura 14 - detalhamento esquemático das etapas envolvidas na síntese e funcionalização das NPMs, bem como da dispersão das mesmas para formar FMs. 
Figura 15 - as várias etapas na síntese de um FM iônico: frasco de reação antes (a) e após (b) a mistura de metais contida na solução da seringa com o $\mathrm{NaOH}$ contido no béquer; c) separação magnética do precipitado obtido, após 30 min de síntese e; d) fluido magnético obtido após tratamento de superfície e peptização das NPs.

Figura 16 - diagrama esquemático representando a estabilidade coloidal, as cargas de superfície e os grupos associados a essas cargas, em função do pH. pKa1 e pKa1 representam os valores das constantes de dissociação ácida dos grupos de superfície e IEP representa o ponto isoelétrico, em $\mathrm{pH} \sim 7$ para as NPMs aqui estudadas.

Figura 17 - imagem obtida por TEM para a amostra de FM iônico.

Figura 18 - histograma de distribuição em tamanho obtido a partir da contagem da frequência das NPs em função do diâmetro (via programa ImageJ).

Figura 19 - difratograma de raios $X$ obtido para as nanopartículas sintetizadas.

Figura 20. difratograma mostrando os dados experimentais (pontos) e o ajuste teórico e a análise de erro utilizando o método de Rietveld (linha).

Figura 21 - representação da complexação da superfície das NPMs pelos ligantes ácido glicérico e ácido glucônico $(\mathrm{R}-\mathrm{COOH})$ via carboxilato.

Figura 22 - diagramas de especiação da superfície das NPMs (em vermelho) e dos ligantes (em azul). As constantes de dissociação ácidas das NPs (pKa1 e pKa2) e do ligante (pKL), assim como o pH ideal de complexação, estão indicados na figura.

Figura 23 - espectros de FTIR para as amostras de NPs funcionalizadas com ácido glicérico (GYANP) e ácido glucônico (GUANP), evidenciando a interação dos ligantes com a NP (acima) e (abaixo) contribuição da ferrita (NPM), para o espectro.

Figura 24 - variação do potencial zeta, em função do pH, para NPs funcionalizadas com ácido glicérico (GYANP) e ácido glucônico (GUANP) e sem funcionalização (NFNP).

Figura 25 - modelo de interação entre a superfície modificada das NPMs e o glicerol.

Figura 26 - aspecto das dispersões de NPs funcionalizadas com ácido glucônico em diversos solvente, após serem submetidas a um campo magnético estático.

Figura 27 - variação da densidade em função da concentração em massa de um sol.

Figura 28 - variação da densidade para o fluido magético constituído de NPS não funcionalizadas, obtido no procedimento descrito na seção 3.1 .

Figura 29 - gráfico da densidade em função da fração em massa para a amostra não funcionalizada, calculada de acordo com o modelo proposto no texto.

Figura 30 - gráfico da densidade em função da fração em massa para as amostras funcionalizadas com ácido glicérico e glucônico.

Figura 31 - Curva de magnetização versus campo magnético aplicado para as NPs não funcionalizadas. O gráfico em detalhe mostra a histerese.

Figura 32 - curvas de magnetização versus campo magnético aplicado para os FMs constituídos de NPs não funcionalizadas e funcionalizadas.

Figura 33 - curvas de magnetização, normalizadas pela concentração do sol, para os FMs constituídos de NPs não funcionalizadas e funcionalizadas. 


\section{LISTA DE TABELAS}

Tabela 1 - parâmetros refinados, fatores de qualidade e residuais.

Tabela 2 - dados químicos dos ligantes utilizados no trabalho

Tabela 3 - dados de diluição de e densidade para as amostras analisadas. 


\section{LISTA DE ABREVIATURAS E SIGLAS}

\begin{tabular}{|c|c|c|}
\hline DRX & ........ & Difração de raios $X$ \\
\hline EDAC & & 1-ethyl-3-(3-Dimethylaminopropyl) carbodiimide \\
\hline FM & & Fluido Magnético \\
\hline FTIR & & Fourrier Transform Infrared Spectroscopy \\
\hline GUANP & ........ & Nanopartículas funcionalizadas com Ác. Glucônico \\
\hline GYANP & & Nanopartículas funcionalizadas com Ác. Glicérico \\
\hline $\mathrm{Hc}$ & $\ldots .$. & Campo Coercitivo \\
\hline ICP-OES & ..... & $\begin{array}{l}\text { Inductively Coupled Plasma Optical Emission Spectrometry } \\
\text { (Espectrometria de Emissão Óptica por Plasma Acoplado } \\
\text { Indutivamente) }\end{array}$ \\
\hline IEP & …................. & Isoelectric Point (Ponto Isoelétrico) \\
\hline M & ....... & Metal \\
\hline Ms & ....... & Magnetização de Saturação \\
\hline $\mathrm{Mr}$ & .. & Magnetização Remanente \\
\hline NFNP & ........ & Nanopartícula não funcionalizada \\
\hline NPs & ........ & Nanopartículas \\
\hline NPM & ….................. & Nanopartícula Magnética \\
\hline TEM & . & $\begin{array}{l}\text { Transmission Electron Microscopy } \\
\text { (Microscopia Eletrônica de Transmissão) }\end{array}$ \\
\hline
\end{tabular}




\section{SUMÁRIO}

1. INTRODUÇÃO 02

1.1 OS FLUIDOS MAGNÉTICOS 05

1.2 ALGUMAS PROPRIEDADES MAGNÉTICAS DOS FM 11

1.3 O MAGNETISMO DAS FERRITAS 13

1.4 A MAGNETIZAÇÃO DE UM FLUIDO MAGNÉTICO 17

1.5 O MODELO DE GLICONANOPARTÍCULAS 19

2. OBJETIVOS 26

3. MATERIAIS E MÉTODOS 28

3.1 ELABORAÇÃO DAS AMOSTRAS 30

3.2 CARACTERIZAÇÃO DAS AMOSTRAS 32

3.2.1 MICROSCOPIA ELETRÕNICA DE TRANSMISSÃO (MET) 32

3.2.2 DIFRAÇÃO DE RAIOS X (DRX) 33

3.2.3 ESPECTROSCOPIA DE EMISSÃO ATÕMICA POR PLASMA

3.2.4 ESPECTROSCOPIA DE ABSORÇÃO NO INFRAVERMELHO COM

TRANSFORMADA DE FOURRIER 35

3.2.5 MEDIDAS DE DENSIDADE 36

3.2.6 MEDIDAS DO POTENCIAL ZETA (POTENCIAL ELETROCINÉTICO) 36

3.2.7 MEDIDAS DE MAGNETIZAÇÃO

4. RESULTADOS E DISCUSSÃO 38

4.1 SÍNTESE DE NPMs E ELABORAÇÃO DDE FLUIDO IÔNICO EM MEIO

AQUOSO 39

4.2 CARACTERIZAÇÃO QUÍMICA, MORFOLÓGICA E ESTRUTURAL DAS

NANOPARTÍCULAS 43

4.3 FUNCIONALIZAÇÃO DAS NANOPARTÍCULAS E PEPTIZAÇÃO EM MEIO NÃO AQUOSO 48

4.4 MEDIDA DE CONCENTRAÇÃO DO COLOIDE PELA DENSIDADE DO FLUIDO 58

4.5 CARACTERIZAÇÃO MAGNÉTICA 64

5. CONCLUSÕES E PERSPECTIVAS 67

BIBLIOGRAFIA $\quad 70$ 
Introdução 


\section{Introdução}

A nanotecnologia tem permitido aos cientistas direcionarem suas pesquisas em uma região dimensional entre o nível molecular e submicroscópico. De fato, vistos como moléculas, os nanomateriais dão acesso a respostas quânticas até então não acessíveis e, vistos como partículas, estes materiais apresentam características não observadas em estruturas maiores (mesmo que $100 \mathrm{~nm}$ ). É nesse domínio de dimensão que muitos avanços recentes têm sido feitos em diversos campos da ciência e em setores tecnológicos que vão desde a engenharia, até a biotecnologia [1]. Dentre os vários tipos de nanopartículas (NP), as nanopartículas magnéticas (NPM) têm recebido especial atenção, não apenas pelas suas características fundamentais [2], mas por suas potenciais aplicações biotecnológicas em imagens por ressonância magnética nuclear [3], bioadsorção magnética de poluentes [4], técnicas magnetotérmicas de tratamento de câncer [5], separação e/ou purificação de DNA e proteínas [6], carreamento e liberação controlada de fármacos [7]. A versatilidade de tais materiais como ferramenta na medicina surge, uma vez que as NPs possuem dimensões menores ou comparáveis a de uma célula, um vírus, uma proteína ou mesmo de um gene, as mesmas podem, facilmente, interagir com uma entidade biológica de interesse, além de permear pelos compartimentos diferenciados do organismo; as NPMs podem ser recobertas, ou seja, funcionalizadas por moléculas bioativas, por exemplo, moléculas orgânicas, polímeros, anticorpos, etc, isto é, materiais facilmente reconhecidos por células, tecidos e órgãos do corpo humano, otimizando sua interação com o organismo, ou mesmo tornando-as pontualmente específicas a uma determinada região ou alvo; uma vez que são magnéticas, as NPs podem ser 
facilmente manipuladas por um gradiente de campo magnético externo. Essa "ação à distância", combinada com a intrínseca penetrabilidade dos campos magnéticos em tecidos humanos, oferece muitas aplicações envolvendo o transporte, manipulação e imobilização dessas entidades biológicas magneticamente caracterizadas.

Nessa direção, para otimizar as aplicações existentes e abrir outras novas, é necessário aprimorar as técnicas de elaboração e compreender/dominar melhor as propriedades dessas NPMs. O controle preciso das condições de síntese e da funcionalização de superfície é crucial, já que essas etapas governam as propriedades físicas e físico-químicas, estabilidade coloidal e o comportamento/destino biológico das NPs. Para aplicações farmacêuticas e fins biomédicos, as estruturas devem apresentar tamanhos diminutos e polidispersão estreita, juntamente com altos valores de magnetização e susceptibilidade para uma melhor resposta magnética. Particularmente, um recobrimento adequado de superfície é necessário a fim de se assegurar tolerância e bicompatibilidade, assim como especificidade e proteção, às NPMs. Usualmente, solubilidade em meios aquosos e isotônicos também é exigida para aplicações biológicas. Nesses casos, as nanopartículas, quase sempre, estão dispersas em um líquido, para formar um fluido magnético (FM), ferrofluido, ou líquido magnético.

Os materiais que fazem esses recobrimentos de superfície devem ser biocompatíveis e biodegradáveis, proporcionar estabilidade coloidal e, idealmente, permitir o reconhecimento e conexão com biomoléculas [8]. Nos polímeros, e nas moléculas mais curtas, que são usualmente empregados para esse recobrimento, funções orgânicas como aminas, carboxilas, tiois e hidroxilas são particularmente desejáveis. Na maioria desses FMs, a repulsão necessária para peptização das 
nanopartículas é originada, eletrostaticamente, a partir das cargas elétricas presentes na superfície dos nanomateriais, por repulsão estérica, devido à presença de surfactantes ou, ainda, uma mistura delas, pela adsorção de moléculas polifuncionais. Entretanto, conforme discutido adiante, esses modelos apresentam limitações de uso relacionadas a pH, força iônica e tipo de solvente, que podem servir de entraves para algumas aplicações.

É nessa direção que esse trabalho visa à elaboração de nanopartículas magnéticas de ferrita mista de cobalto e manganês, com diâmetro médio aproximado de $15 \mathrm{~nm}$ e sua funcionalização com moléculas de ácido glicérico e ácido glucônico. Particularmente, as cadeias contendo grupamentos hidroxila $(\mathrm{OH})$ mimetizam vários solventes como álcoois e poliois, além de meios biológicos, em que a peptização de nanopartículas não é facilmente contemplada pelos modelos tradicionais. Para fins de estudo, a composição química, a estrutura cristalina, as propriedades magnéticas, a morfologia e tamanho das nanopartículas foram investigadas. A eficiência de funcionalização e de dispersão dessas NPs funcionalizadas em diferentes solventes também foi avaliada e, um modelo, a partir de medidas de densidade dos fluidos, foi proposto para determinação da concentração dos coloides obtidos. Esses materiais são candidatos promissores para interagirem com o meio biológico, devido à grande afinidade dos ligantes de superfície escolhidos, com esse meio. 


\subsection{Os Fluidos Magnéticos}

A concepção de um fluido magnético está focada em um material - não existente na natureza - que apresente a fluidez dos líquidos ordinários e que, ao mesmo tempo, possua propriedades magnéticas, somente características de alguns sólidos. O mercúrio e o gálio, metais líquidos em temperaturas moderadas, são diamagnéticos. Metais ferromagnéticos, como o ferro e o níquel, são líquidos apenas em altas temperaturas, nas quais, entretanto, se tornam paramagnéticos. Nesse sentido, a obtenção de fluidos magnéticos se voltou à junção de partículas sólidas magnéticas (metais, ligas, compósitos, óxidos, etc.) e fluidos (diversos solventes, óleos, graxas, etc.), de maneira a formar um sistema coloidal, cuja resposta fosse homogênea face à aplicação de um campo magnético externo, mesmo que de menor intensidade.

Foi nessa direção que, nos anos 1930, nas primeiras tentativas de se obter um fluido magnético, partículas de magnetita, reduzidas mecanicamente a dimensões micrométricas, foram dispersas em solventes orgânicos. Porém, devido à dimensão das partículas, não houve estabilidade do sistema coloidal $[9,10]$. Somente a partir dos anos 1960, fluidos magnéticos, relativamente mais estáveis, foram preparados, a partir da trituração de blocos magnetita (em partículas de cerca de $10 \mathrm{~nm}$ ), na presença de surfactantes e solventes orgânicos ou água $[11,12]$. Nos anos 1970, fluidos magnéticos estáveis foram obtidos a partir da dispersão de nanopartículas magnéticas de óxido de ferro obtidas quimicamente, em solventes variados, com auxílio de surfactantes [13], ou em água, eletrostaticamente [14].

Essas primeiras metodologias, que garantiram sucesso quanto à estabilidade coloidal, se baseavam no fato de que, pelas leis da hidrodinâmica, nanopartículas nanométricas poderiam permanecer indefinidamente em suspensão num líquido, mesmo 
que a diferença de densidade entre essas fases fosse grande - as colisões contínuas das moléculas do solvente, animadas pelo movimento browniano, com as partículas magnéticas, forneceriam a energia cinética necessária para garantir a estabilidade da suspensão. Entretanto, isso é válido somente para sistemas diluídos - a presença de um grande número de partículas aumenta a probabilidade de choques interpartículas, induzindo a aglomeração das mesmas e a coagulação do coloide. No caso específico de um fluido magnético, o adequado balanço de energias é o que poderá promover a estabilidade coloidal do sistema. As nanopartículas magnéticas devem apresentar dimensões manométricas $(<20 \mathrm{~nm})$, buscando equilíbrio entre o termo entrópico e a força gravitacional. Por outro lado, com o intuito de garantir distância mínima interparticular, forças de caráter repulsivo devem ser introduzidas, a fim de se estabelecer equilíbrio com as forças atrativas de curto alcance, como a de Van der Waals e, pelo fato de as partículas serem magnéticas, com a interação dipolar magnética [15].

A partir de então, as metodologias empregadas para preparação de fluidos magnéticos têm se baseado nesses modelos e envolvem, nas mais variadas aplicações, pelo menos três etapas: síntese, modificação de superfície e peptização das nanopartículas magnéticas em um solvente.

Apesar de apresentarem altos valores de magnetização e propriedades magnéticas singulares, nanopartículas magnéticas metálicas quase nunca são empregadas na elaboração de fluidos magnéticos, visto que oxidam facilmente e, para aplicações biomédicas, apresentam toxicidade elevada. Por outro lado, as nanopartículas mais utilizadas são, sem dúvida, as ferritas magnéticas, especialmente magnetita $\left(\mathrm{Fe}_{3} \mathrm{O}_{4}\right)$ e maguemita $\left(\gamma-\mathrm{Fe}_{2} \mathrm{O}_{3}\right)$, por sua facilidade de síntese e grande aplicabilidade na área biomédica, devido a sua biocompatibilidade e biodegradabilidade. São variados os 
métodos de síntese desses nanomateriais - os processos físicos, como deposição em fase gasosa e litografia por feixe de elétrons, são bastante limitados pela sua inabilidade para controlar o tamanho das partículas magnéticas em nanoescala [16] e, por isso, pouco utilizados. Já os processos químicos permitem maior controle da morfologia, do tamanho e das propriedades físicas e físico-químicas dos nanomateriais. Por isso, são mais empregados e exemplos são sínteses por coprecipitação [17], decomposição térmica [18], reação hidrotérmica, [19] processos sol-gel [20], nanoreatores [21], oxidação [22], injeção de fluxo [23], processos eletroquímicos [24], aerossol [25], decomposição sonoquímica [26] e fluidos supercríticos [27]. Dentre esses métodos, especial atenção tem sido dada às sínteses por coprecipitação em meio aquoso, já que são procedimentos simples, menos dispendiosos e têm alto rendimento. Além disso, não envolvem reagentes orgânicos ou solventes mais tóxicos, o que aumenta o potencial das nanopartículas para aplicações na área biomédica. Entretanto, se comparada à decomposição térmica, a coprecipitação gera nanomateriais com polidispersão, sendo mais difícil, inclusive, o controle do tamanho das nanopartículas. De maneira alternativa, grande parte das pesquisas nessa área tem sido direcionada à utilização de óxidos de ferro dopados com metais de transição, mais especificamente as ferritas do tipo $\mathrm{MFe}_{2} \mathrm{O}_{4}$, em que $\mathrm{M}$ geralmente é $\mathrm{Mn}, \mathrm{Fe}, \mathrm{Co}, \mathrm{Ni}, \mathrm{Cu}, \mathrm{Zn}$, etc. A síntese desses nanomateriais emprega as mesmas rotas descritas anteriormente e essas nanopartículas apresentam propriedades, principalmente magnéticas, distintas da magnetita e da maguemita e que são bastante apreciadas nos diferentes ramos de aplicação.

Conforme anteriormente destacado, para que as nanopartículas sejam dispersas (peptizadas), na forma de uma suspensão coloidal estável (sol), forças de caráter repulsivo devem ser introduzidas na superfície das mesmas. O tipo de meio carreador 
escolhido é consequência direta do método de estabilização escolhido para dispersar essas nanopartículas. A figura 1 ilustra as principais estratégias empregadas para tal: a quimiosorção de agentes tensoativos na superfície das partículas magnéticas gera um impedimento estérico (físico) entre as mesmas, contrapondo-se a floculação devido às forças atrativas. Este metodologia é especialmente indicada para a peptização em solventes moleculares do tipo apolar (solventes orgânicos apolares). Neste caso, é realizada uma surfactação simples, em que um agente tensoativo fixa sua "extremidade polar" à superfície da partícula, deixando sua "cauda" apolar voltada para a solução. No caso de solventes polares e água, este método é menos indicado, já que exige uma dupla surfactação, em que um segundo tensoativo interage com o primeiro, pelas extremidades hidrofóbicas, deixando sua extremidade polar voltada para o meio solvente.

A protonação/desprotonação da superfície de nanopartículas de óxidos, por meio de equilíbrios do tipo ácido-base, cria uma densidade superficial de carga positiva ou negativa (dependendo do $\mathrm{pH}$ ) e, assim, uma dupla camada elétrica. Isto dá origem à repulsão eletrostática que se contrapõe as forças atrativas de Van der Waals e de dipolo magnético. Este modelo é aplicado, com vantagem, ao meio aquoso, no qual esses equilíbrios iônicos são passíveis de acontecer. Os FM assim preparados são chamados de iônicos ou com dupla camada elétrica e são bastante empregados, uma vez que, nessa forma, as NPs podem ser modificadas posteriormente para dispersão por outros modelos ou para aplicações específicas. A quimiosorção de moléculas polifuncionais gera impedimento, ao mesmo tempo estérico e eletrostático. Diferentemente do modelo de surfactação, que exige moléculas de cadeias longas, moléculas de cadeias menores podem ser utilizadas, desde que apresentem grupos capazes de se ligar à superfície das NPs e, na cadeia orgânica, outros grupamentos hábeis para se ionizar e gerar cargas 
elétricas. Normalmente, são utilizadas moléculas orgânicas contendo ácidos carboxílicos, aminas e tiois que desempenham bem esse papel. Esse modelo tem grande afinidade com os meios aquosos, inclusive isotônicos, o que aumenta sua aplicabilidade na área biomédica. Além disso, esses polieletrólitos podem agir como cross-linkers para o acoplamento de espécies mais complexas, como peptídeos, proteínas e anticorpos.

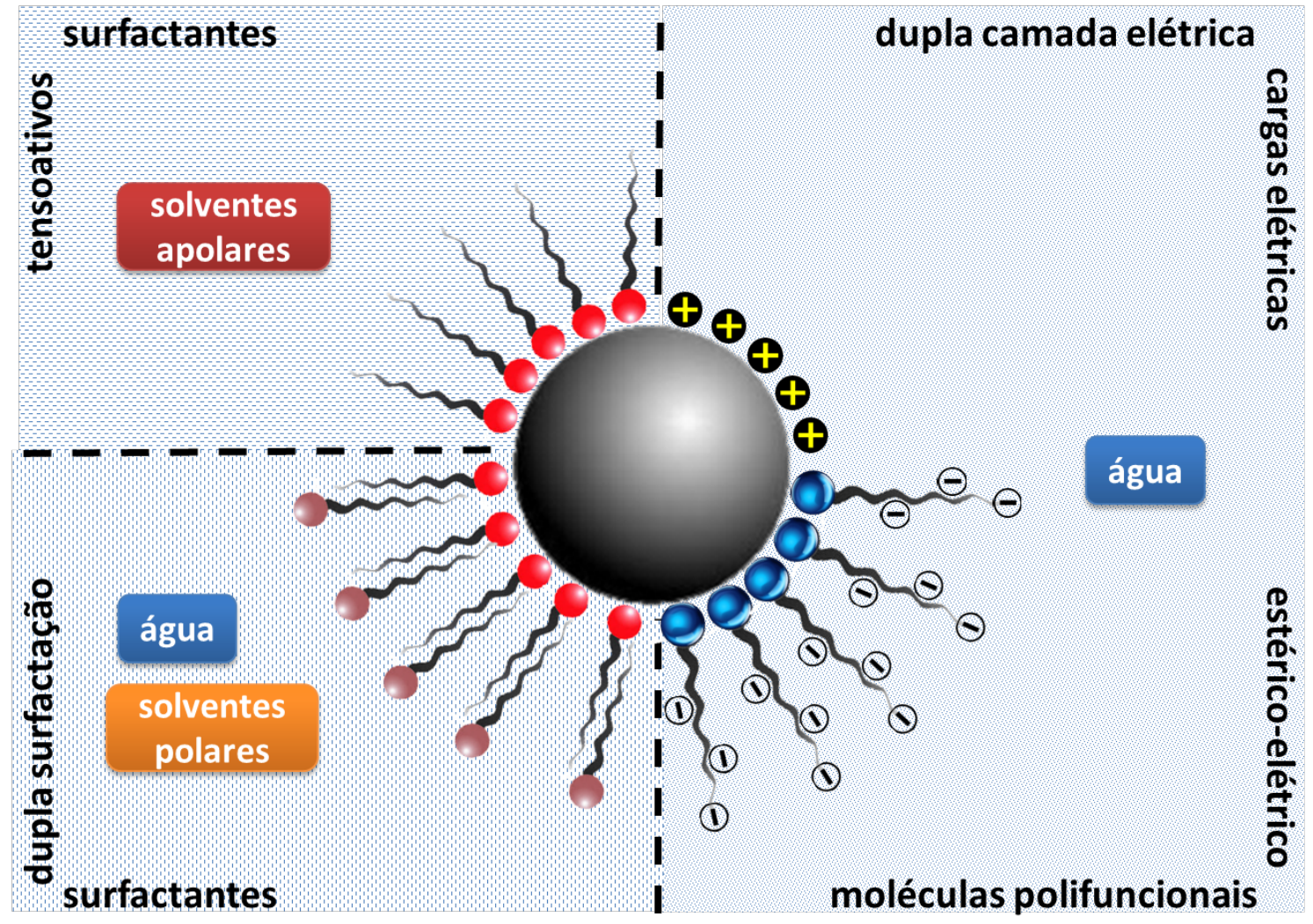

Figura 1 - Esquematização dos modelos de estabilização coloidal: em água, as NPs podem ser dispersas pela adsorção de cargas elétricas, por ionização de sítios superficiais (cargas positivas em amarelo) ou pela adsorção e ionização de moléculas polifuncionais (estruturas azuis carregadas negativamente). Podem ser peptizadas em solventes apolares, por simples surfactação - e em solventes polares, por dupla surfactação - com tensoativos (estruturas em vermelho e lilás). 
Além de promover estabilização coloidal, a modificação da superfície fornece proteção química/física para NPs e permite sua aplicabilidade nas mais diferentes áreas, como é o caso de aplicações em biomedicina. Nessa direção, a modificação de superfície também proporciona funcionalização para posterior conjugação com moléculas bioativas ou ligantes específicos e para obtenção de materiais multifuncionais [28]. Além das metodologias ilustradas na figura 1, outros modelos mais complexos, mas que envolvem àqueles apresentados anteriormente, podem ser adotados para funcionalização/estabilização das NPs, conforme ilustrado na figura 2.

As NP podem ser encapsuladas, por polímeros orgânicos, compostos inorgânicos, metais ou ligas metálicas, individualmente em um modelo core-shell, ou em um sistema de nanoesfera polinucleada, conforme ilustrado nas figuras 2 (a) e (b), respectivamente. Além disso, as NPs podem estar dispersas em fluidos confinados em cápsulas poliméricas, sistemas micelares, vesiculares ou lipossômicos, conforme mostrado em (c).

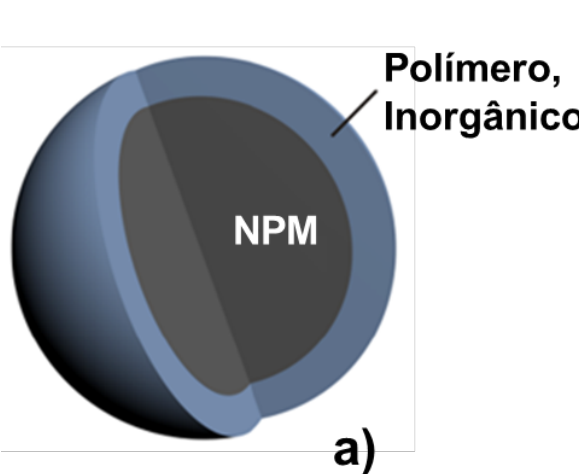

a)
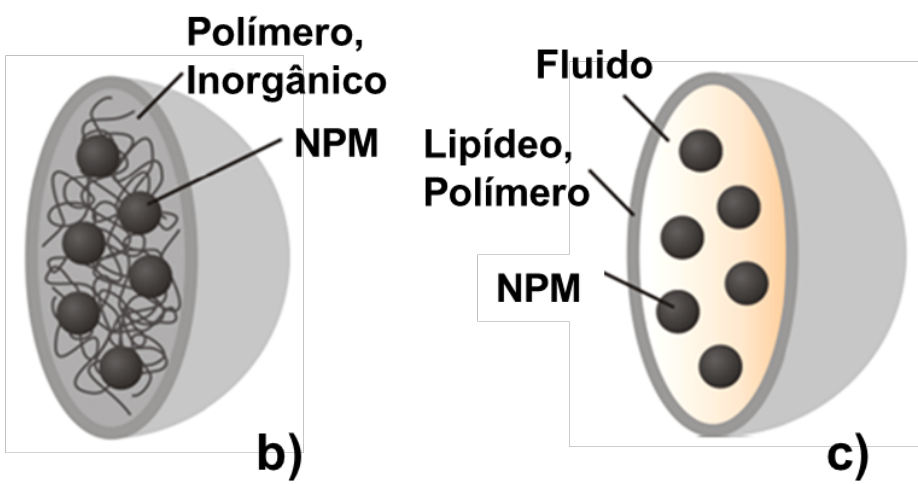

Figura 2 - Modelos de funcionalização de nanopartículas magnéticas (NPM): a) núcleo-casca (coreshell), b) sistema maciço polinucleado e c) encapsulamento 


\subsection{Algumas propriedades magnéticas dos FM}

Para compreender as propriedades magnéticas dos FMs, é necessário, inicialmente, conhecer as características das NPMs, já que são a contrapartida magnética desses materiais. Por sua vez, essas características são resultado da composição, morfologia, dimensão e estrutura cristalográfica desses nanomateriais.

As ferritas $\mathrm{MFe}_{2} \mathrm{O}_{4}$, em que $\mathrm{M}=\mathrm{Mn}^{2+}, \mathrm{Fe}^{2+}, \mathrm{Co}^{2+}, \mathrm{Ni}^{2+}, \mathrm{Cu}^{2+}, \mathrm{Zn}^{2+}$, apresentam arranjo cristalino do tipo espinélio [29], cuja cela unitária é formada por um empacotamento cúbico compacto de face centrada de 32 ânions $\mathrm{O}^{2-}$ que geram 64 interstícios tetraédricos e 32 octaédricos parcialmente ocupados pelos cátions metálicos $\mathrm{M}^{2+}$ e $\mathrm{Fe}^{3+}$ (1/8 dos sítios tetraédricos e 1/2 dos octaédricos). A figura 3 mostra, esquematicamente, a cela unitária da estrutura espinélio, na qual as esferas verdes representam os átomos de oxigênio, as vermelhas simbolizam os átomos nos interstícios tetraédricos e as amarelas, os átomos que ocupam os sítios octaédricos, destacados à direita, na figura.

Quando existem somente átomos do metal divalente (M) nos sítios tetraédricos e $\mathrm{Fe}^{3+}$ nos sítios octaédricos, a estrutura é classificada como espinélio normal. No caso do $\mathrm{Fe}^{3+}$ ocupar os sítios tetraédricos e metade dos octaédricos, e o metal divalente a outra metade dos octaédricos, o espinélio é classificado como inverso. Isso pode ser mais bem visualizado, ao se utilizar a fórmula cristalográfica $\left[\left(\mathrm{M}_{1-\theta} \mathrm{Fe}_{\theta}\right)_{\mathrm{A}}\left(\mathrm{M}_{\theta} \mathrm{Fe}_{2-\theta}\right)_{\mathrm{B}}\right] \mathrm{O}_{4}$, em que A representa os sítios tetraédricos e B os octaédricos. Nessa equação, quando $\theta$, que é o parâmetro de ocupação dos íons metálicos, é igual a zero, o espinélio é normal e quando esse valor é unitário, o espinélio é inverso. Entretanto, principalmente na escala nano, quase sempre $0<\theta<1$, e o espinélio é classificado como misto. Além disso, mais de um metal pode compor a ferrita para formar um composto do tipo $\mathrm{M}_{(1-\mathrm{x})}^{1} \mathrm{M}_{\mathrm{x}}^{2} \mathrm{Fe}_{2} \mathrm{O}_{4}$, em 
que $\mathrm{M}^{1}$ e $\mathrm{M}^{2}$ são diferentes metais $\left(\mathrm{Mn}^{2+}, \mathrm{Fe}^{2+}, \mathrm{Co}^{2+}, \mathrm{Ni}^{2+}, \mathrm{Cu}^{2+}, \mathrm{Zn}^{2+}\right)$. Por exemplo, sabe-se que a ferrita de cobalto $\left(\mathrm{CoFe}_{2} \mathrm{O}_{4}\right)$ é um material magnético "duro", que tem sido estudado em detalhes devido à sua alta coercividade e moderada saturação de magnetização, assim como estabilidade química e dureza mecânica [30]. Entretanto, os altos valores de magnetorestrição e acoplamento magnetomecânico são limitações que limitam a aplicação desses materiais em diversos campos, como o da biomedicina [31]. Porém, a substituição por outros elementos, como o manganês $\left(\mathrm{Mn}_{1-x} \mathrm{Co}_{x} \mathrm{Fe}_{2} \mathrm{O}_{4}\right)$, tem sido proposta para manipular essas restrições, permitindo maior controle das propriedades magnéticas e magneto-ópticas desses nanomateriais [32].

Existem, também, ferritas compostas por outros metais de transição diferentes do grupo do período ferro e, até com lantanídeos e actinídeos, mas que não são abordadas nesse trabalho [33].
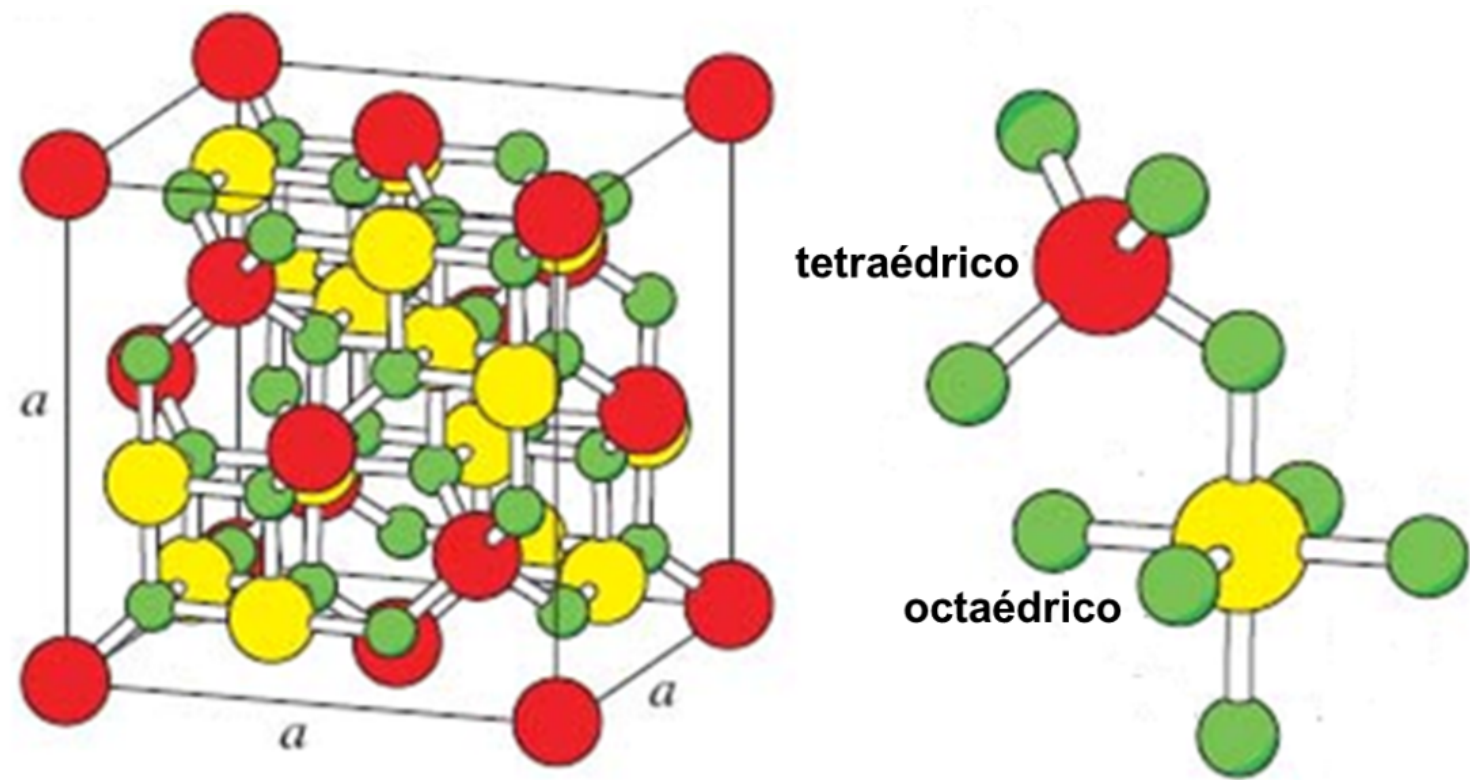

Figura 3 - Representação da cela unitária da estrutura espinélio: as esferas verdes simbolizam os átomos de oxigênio, as vermelhas simbolizam os cátions nos sítios tetraédricos e as amarelas representam os cátions posicionados nos sítios octaédricos. 


\subsection{0 nanomagnetismo das ferritas}

Com base na resposta dos dipolos magnéticos individuais e na magnetização cooperativa, na presença ou ausência de um campo magnético aplicado, as NPMs são tipicamente classificadas como diamagnéticas, paramagnéticas, ferromagnéticas, ferrimagnéticas ou antiferromagnéticas, conforme ilustrado na figura 4. Para os materiais diamagnéticos, inicialmente inexistente na ausência de campo, um dipolo é gerado com orientação antiparalela a um campo aplicado. Para os paramagnéticos, os dipolos - randomicamente distribuídos - se orientam na direção do campo, quando aplicado. Para os materiais em que o magnetismo cooperativo é mais importante, a magnetização na ausência de campo revela suas características fundamentais. Os materiais ferromagnéticos apresentam os dipolos magnéticos alinhados na ausência de campo e, portanto, magnetização espontânea, nessa condição. De maneira contrária, a magnetização em materiais antiferromagnéticos tende a ser nula já que os momentos se orientam antiparalelamente.

\begin{tabular}{|c|c|c|c|c|c|c|}
\hline $\begin{array}{l}\text { sem campo } \\
0000 \\
0000 \\
0000 \\
0000\end{array}$ & $\begin{array}{l}\text { com campo } \\
\Theta \Theta \Theta \Theta \\
\Theta \Theta \Theta \Theta \\
\Theta \Theta \Theta \Theta \\
\Theta \Theta \Theta \Theta\end{array}$ & $\begin{array}{l}\text { sem campo } \\
Q \otimes \emptyset \varnothing \\
Q \varnothing \phi \varnothing \\
\Phi \phi \Phi \varnothing \\
Q \otimes \Phi \ominus\end{array}$ & $\begin{array}{l}\text { com campo } \\
\theta \theta \theta \theta \\
\theta \theta \theta \theta \\
\theta \theta \theta \theta \\
\theta \theta \theta \oplus\end{array}$ & $\begin{array}{l}\text { sem campo } \\
\theta \theta \theta \theta \\
\theta \theta \theta \theta \\
\theta \theta \theta \theta \\
\theta \theta \theta \theta\end{array}$ & 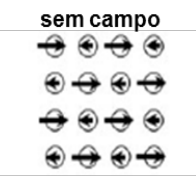 & $\begin{array}{l}\text { sem campo } \\
\theta \theta \theta \theta \\
\theta \theta \theta \theta \\
\theta \theta \theta \theta \\
\theta \theta \theta \theta\end{array}$ \\
\hline \multicolumn{2}{|c|}{ Diamagnetismo } & \multicolumn{2}{|c|}{ Paramagnetismo } & rromagnetisn & Ferrimagnetismo & Antiferromagnetis \\
\hline
\end{tabular}

Figura 4 - Comportamento de dipolos magnéticos, simbolizados pela setas escuras, na presença e ausência de campo magnético externo aplicado. Com base no alinhamento desses dipolos magnéticos, os materiais são classificados como diamagnético, paramagnético, ferromagnético, ferrimagnético e antiferromagnético. 
Nos espinélios, em que a ordem é do tipo ferrimagnética, há um alinhamento antiparalelo dos momentos magnéticos como no antiferromagnetismo. Entretanto, há uma diferença de magnitude entre os momentos alinhados em sentidos contrários e o material apresenta uma magnetização espontânea, porém em menor proporção, como os ferromagnéticos.

Em um sólido magnético, as interações de troca entre os átomos portadores de momento magnético situados em sítios adjacentes induzem um alinhamento paralelo ou antiparalelo dos spins eletrônicos que pode se estender pela estrutura, formando domínios de magnetização. Dependendo da distribuição e da orientação desses momentos magnéticos, a estrutura pode apresentar vários domínios magnéticos com orientações individuais, definidas por critérios energéticos e pela cristalografia do sistema. Entretanto, abaixo de um volume crítico, a nanoestrutura tende a formar um monodomínio magnético. Nos óxidos espinélio, os metais se encontram separados por átomos de oxigênio, de forma que as interações de troca somente são possíveis via orbitais $p$ do oxigênio e são chamadas de "interações de supertroca" [34]. Nesse caso, as constantes de troca dependem, principalmente, dos tipos de íons e das distâncias e dos ângulos de ligação entre esses átomos. Nas ferritas, as interações de toca são sempre negativas entre os sítios A e B, ou seja, há um alinhamento antiparalelo global entre os spins nos sítios octaédricos e tetraédricos. Nos sítios tetraédricos, os momentos magnéticos são todos paralelos. Por outro lado, os sítios B são subdivididos em duas sub-redes, cujos ambientes cristalográficos são diferenciados. Assim, nas ferritas normais, as interações BB são negativas (os spins dos íons ferro são alinhados antiparalelamente nesses sítios), ao passo que, nas ferritas inversas, essas interações são positivas (os spins dos íons ferro são alinhados paralelamente aos spins dos íons do metal divalente). De uma maneira geral, a magnetização de uma ferrita (normal ou 
inversa) é função dos momentos magnéticos dos íons divalentes, uma vez que os momentos dos íons ferro se anulam, nos dois casos.

Abaixo de certos valores críticos de dimensão, nanomateriais podem exibir respostas magnéticas remanescentes do paramagnetismo, que é um momento magnético médio nulo na ausência de campo, mas que rapidamente aumenta quando um campo magnético é aplicado. Pelo fato dos valores de magnetização serem bem maiores que aqueles observados no paramagnetismo, esse comportamento é chamado de superparamagnetismo. Esse fenômeno é observado acima de temperaturas específicas, chamadas de temperatura de bloqueio, e se origina das flutuações térmicas que induzem os momentos magnéticos a uma orientação randômica.

A figura 5 mostra curvas típicas de magnetização para materiais ferro e ferrimagnéticos em que parâmetros característicos são destacados: a magnetização máxima possível, chamada de magnetização de saturação $\left(M_{\mathrm{s}}\right)$, que ocorre quando os dipolos magnéticos estão maximamente alinhados com o campo aplicado; magnetização remanente $\left(M_{\mathrm{r}}\right)$, que é a magnetização induzida após remoção do campo magnético aplicado; e coercitividade $(H r)$, que é a intensidade do campo coercitivo necessário para forçar a magnetização para zero. Na mesma figura, em contraste com a histerese observada para materiais ferro(ferri)magnéticos (linha vermelha), a resposta de um material superparamagnético também segue uma sigmoide, mas sem histerese (linha verde). As respostas de materais paramagnéticos (azul) e diamagnéticos (preto) também são ilustradas na figura. 


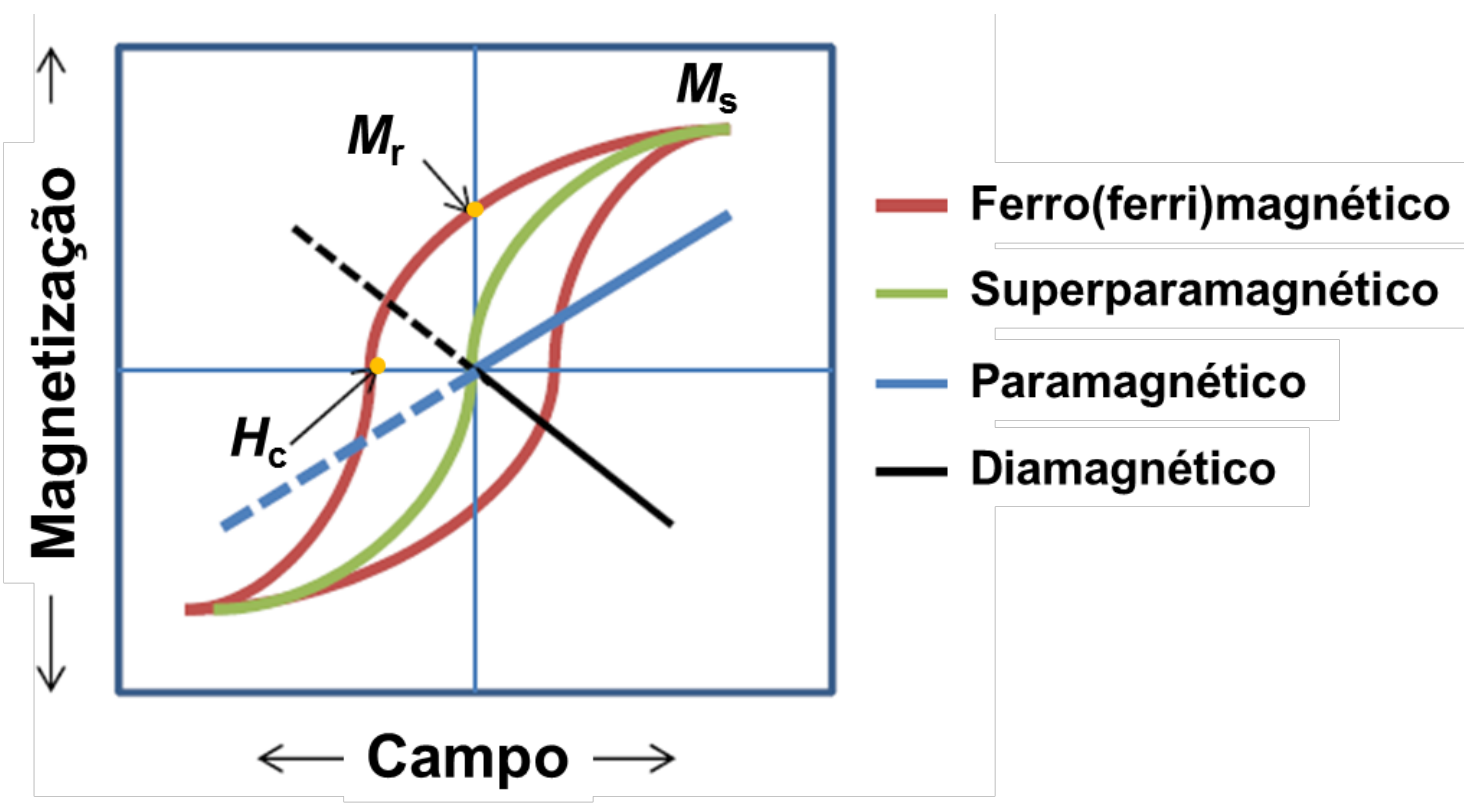

Figura 5 - Comportamento magnético sob a influência de um campo magnético. As curvas de magnetização (magnetização $\times$ campo magnético) para os diferentes tipos de materiais são plotadas no gráfico. Os valores de magnetização de saturação $\left(M_{\mathrm{s}}\right)$ magnetização remanente $\left(M_{\mathrm{r}}\right)$ e de campo coercitivo $\left(H_{\mathrm{c}}\right)$ são destacados na figura.

No equilíbrio, o momento magnético de um monodomínio é orientado paralelamente à direção de fácil magnetização e mantido assim devido à barreira de anisotropia. O mecanismo de rotação desse momento magnético é um processo termicamente ativado com um tempo de relaxação característico que depende da relação entre energia de anisotropia e energia térmica [35]. Em termos simplificados, quando, a energia de anisotropia é superior à energia térmica, o momento magnético é bloqueado na direção de fácil magnetização e o sistema é qualificado como dipolo rígido. Caso a energia térmica sobrepasse a energia de anisotropia, o momento magnético pode flutuar no interior da partícula e o sistema, sensível às flutuações de Néel, é chamado de dipolo não rígido. A redução à escala nanométrica, entretanto, faz surgir numerosos fenômenos, diferentes daqueles observados nos materiais maciços, que devem ser levados em conta, ao se analisar as propriedades magnéticas desses nanomateriais. Um 
efeito evidente é o aumento da proporção de átomos situados na superfície da NP, em relação aos mais internos. A debilitada coordenação desses átomos reduz, consideravelmente, as suas interações de troca. Assim, se por um lado o reduzido volume induz uma configuração de monodomínio ideal, por outro, induz à existência de uma camada de spins com orientação pouco correlata aos do núcleo da NP [36]. Além disso, a redistribuição catiônica, comum nessa faixa de tamanho, também modifica as propriedades magnéticas das NP.

\subsection{A magnetização de um fluido magnético}

Quando dispersos num líquido carreador, as NPM possuem graus suplementares de liberdade, associados à rotação mecânica, o que conduz a um segundo mecanismo de rotação do momento magnético: a rotação browniana. Assim, na ausência de um campo magnético externo, a magnetização global de um fluido magnético é nula, pois os momentos magnéticos associados a cada partícula ou "monodomínio", giram livremente, seja pelo mecanismo de Néel ou de rotação browniana (ver figura 6). Em presença de um campo magnético aplicado, os momentos magnéticos das partículas tendem a se orientar na direção do campo e o um fluido magnético adquire uma magnetização e podem atingir saturação da magnetização. Em regime diluído, no qual as interações partícula-partícula são desprezíveis, a distribuição de orientação dos momentos magnéticos, em presença de um campo aplicado, resulta do balanço entre a energia magnética das partículas e da sua agitação térmica. O valor de magnetização de saturação é $M_{\mathrm{s}}=m_{\mathrm{s}} \phi, m_{\mathrm{s}}$ sendo a magnetização de saturação da partícula magnética e $\phi$ a fração volumétrica em material magnético no fluido [37]. 


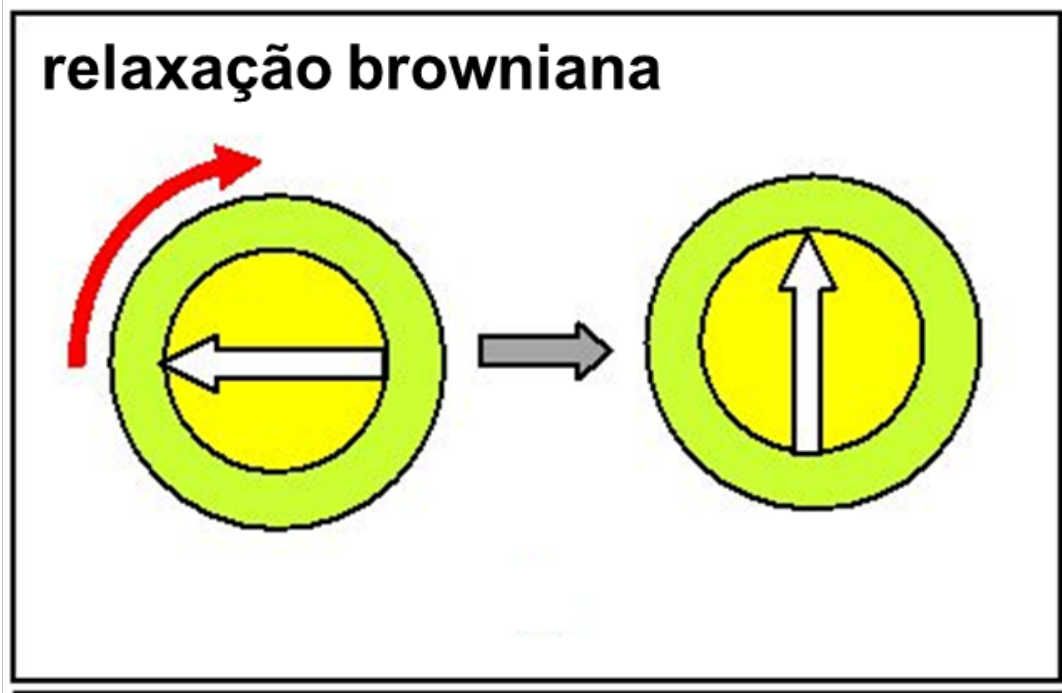

\section{relaxação de Néel}
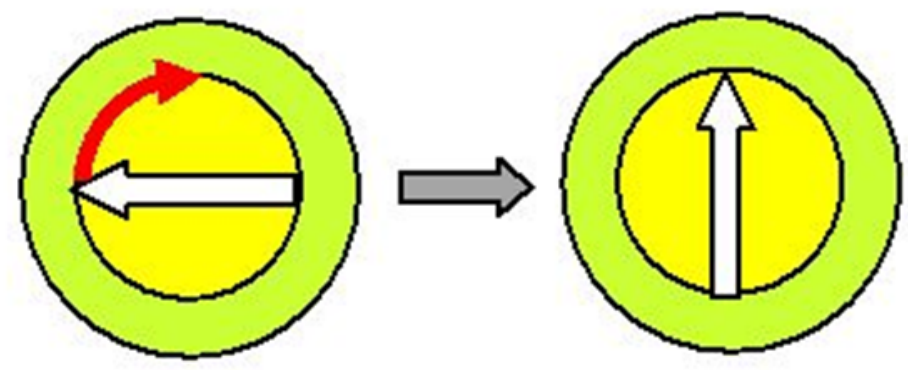

Figura 6 - Modelos de relaxação do momento magnético em um FM: na relaxação browniana a NPM gira em conjunto com o momento magnético do monodomínio. Na relaxação de Néel, o momento magnético gira dentro da estrutura do monodomínio. 


\subsection{O modelo de gliconanopartículas}

$\mathrm{Na}$ funcionalização de NPMs para aplicações biológicas, polímeros biocompatíveis são particularmente interessantes, especialmente polietilenogliclol (PEG) e dextran, para recobrimento dos nanomateriais, uma vez que tendem a ser imunogênicos, não antigênicos, resistentes à adsorção de proteinas, conjugam facilmente com agentes biológicos e fazem com que as NPs sejam quase invisíveis ao sistema imune. Essas propriedades se devem, em grande escala, à presença de grupamentos hidroxila na superfície desses polímeros. Nessa mesma direção, polímeros de carboidratos e derivados de carboidratos são mais hidrofílicos, solúveis em água, biocompatíveis e potencialmente bioativos em relação a certas moléculas. Dessa forma, carboidratos e derivados são utilizados para recobrir NPs, uma vez que podem mimetizar glicoproteinas nos sistemas biológicos e, além disso, podem se envolver em numerosas funções e processos biológicos na superfície da célula como adesão, crescimento celular, processos de metástases e de inflamações [38]. A adsorção desses polímero, entretanto, pode aumentar o volume das NPMs e, por se tratar de materiais “não-magnéticos", os compósitos têm suas magnetizações de saturação reduzidas. Estes efeitos são indesejáveis, já que podem limitar algumas aplicações biomédicas.

É nessa direção que esse trabalho visa à funcionalização das NPMs com moléculas menores, mas que proporcionem um ambiente superficial similar ao daquelas recobertas com os referidos polímeros. Nesse sentido, os ácidos glicérico e glucônico foram escolhidos (ver figura 7). Esses ácidos possuem grupos carboxilatos aptos a se coordenarem à superfície das NPs e cadeias polihidroxiladas capazes de mimetizar a superfície dos polímeros em questão. 


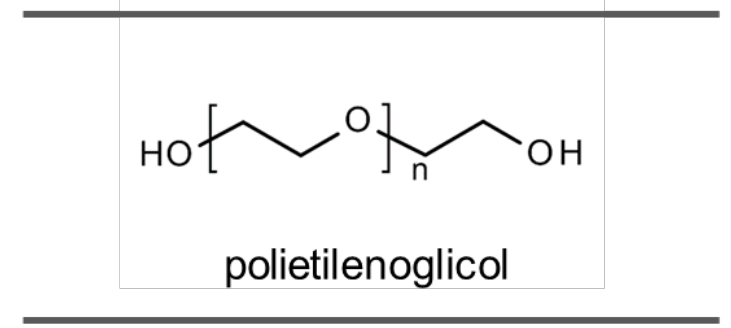<smiles>O=C(O)C(O)CO</smiles>

ácido glicérico

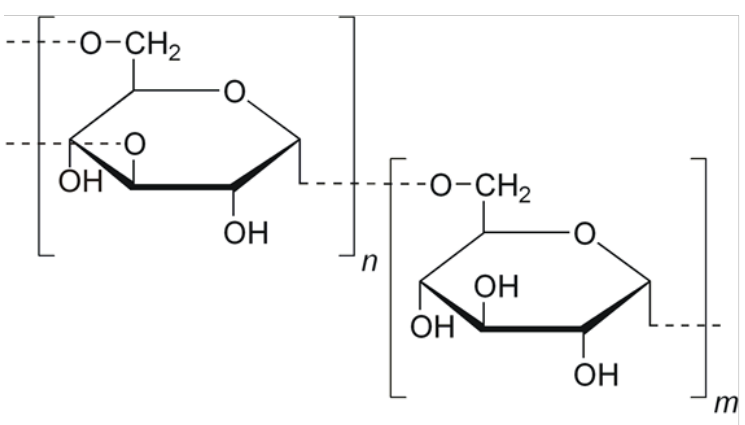

dextran<smiles>O=C(O)[C@H](O)[C@@H](O)[C@H](O)[C@H](O)CO</smiles>

ácido glucônico

Figura 7 - Quadro com as estruturas dos ácidos carboxílicos polihidroxilados, ácido glicérico e ácido glucônico e de polímeros polihidroxilados polietilenoglicol e dextran.

No levantamento bibliográfico efetuado, artigos envolvendo NPMs funcionalizadas com ácido glicérico não foram localizadas. Para o ácido glucônico, poucas referências envolvendo a funcionalização de NPMs foram encontradas. Em um primeiro relato, com a finalidade de produzir FMs, a adsorção de ácido glucônico na superfície de NPs de maghemita, em meio aquoso, foi investigada [39]. Mostrou-se que a adsorção depende de parâmetros como pH e concentração de ligante e que, após complexação dos ligantes, as características de estabilidade coloidal mudam drasticamente. Os autores propuseram que o ácido é adsorvido na sua forma lactônica (ver figura 8) e que a máxima adsorção ocorre com uma relação molar ligante/Fe próxima de $10 \%$, a um $\mathrm{pH}$ médio entre os $\mathrm{p} K_{\mathrm{a}} \mathrm{s}$ da superfície da NP e do ligante. 


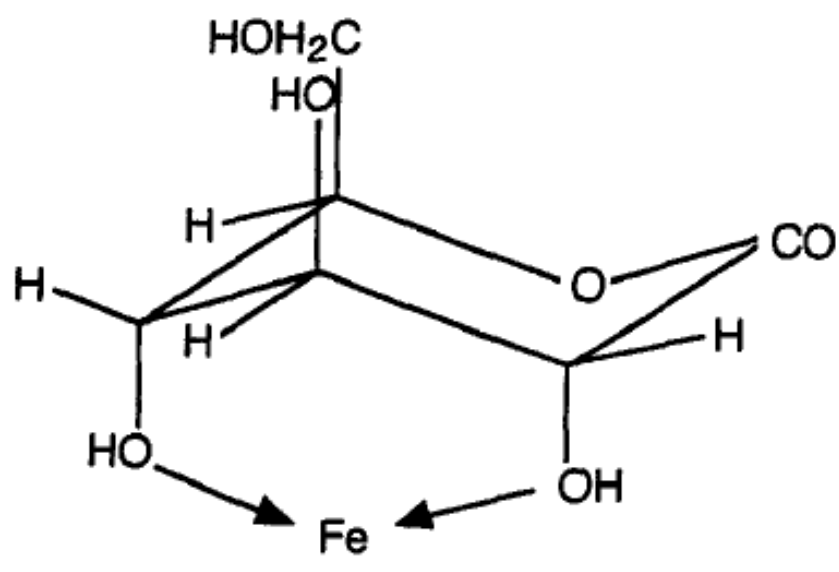

Figura 8 - Modelo de adsorção do ácido glucônico na superfície das NPMs

Em outro trabalho, nanopartículas de $\mathrm{Fe}_{3} \mathrm{O}_{4}$ com polidispersão reduzida são produzidas a partir da reação de $\mathrm{Fe}^{3+}$ com sucrose [40]. Nesse processo, a sucrose é hidrolisada a glucose, um açúcar redutor, que reduz parcialmente o ferro a $\mathrm{Fe}^{2+}$, produzindo a magnetita em meio básico. O ácido glucônico, produto da reação, assim como a glucose produzida em excesso, agem como agentes capeadores, para estabilizar as NPs, conforme esquematizado na figura 9.

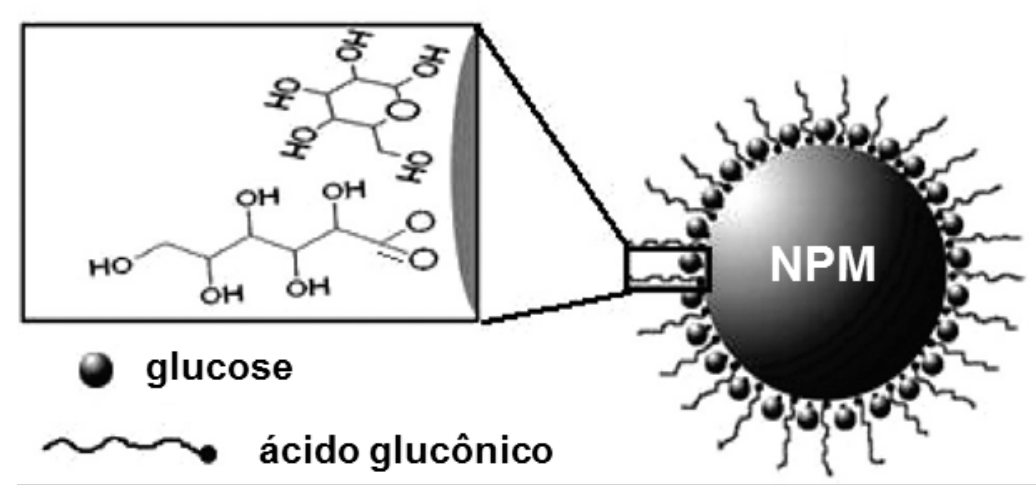

Figura 9 - NPMs de magnetita funcionalizadas com ácido glucônico e glucose. 
Gliconanopartículas, assim designadas pelos autores [41], foram produzidas pela funcionalização de NPs de magnetita, obtidas por coprecipitação alcalina, com vários estabilizantes (carboidratos e derivados), incluindo o ácido glucônico. Experimentos de citotoxicidade mostraram que essas gliconanopartículas revelaram baixa toxicidade, mesmo em concentrações elevadas, conforme mostra o gráfico de viabilidade celular para essas NPMs funcionalizadas, na figura 8. Nesse trabalho, porém, os autores exploram superficialmente o modelo de adsorção do ligante, via carboxilato, e consideram a cadeia polihidrixílica interagindo com o meio biológico.

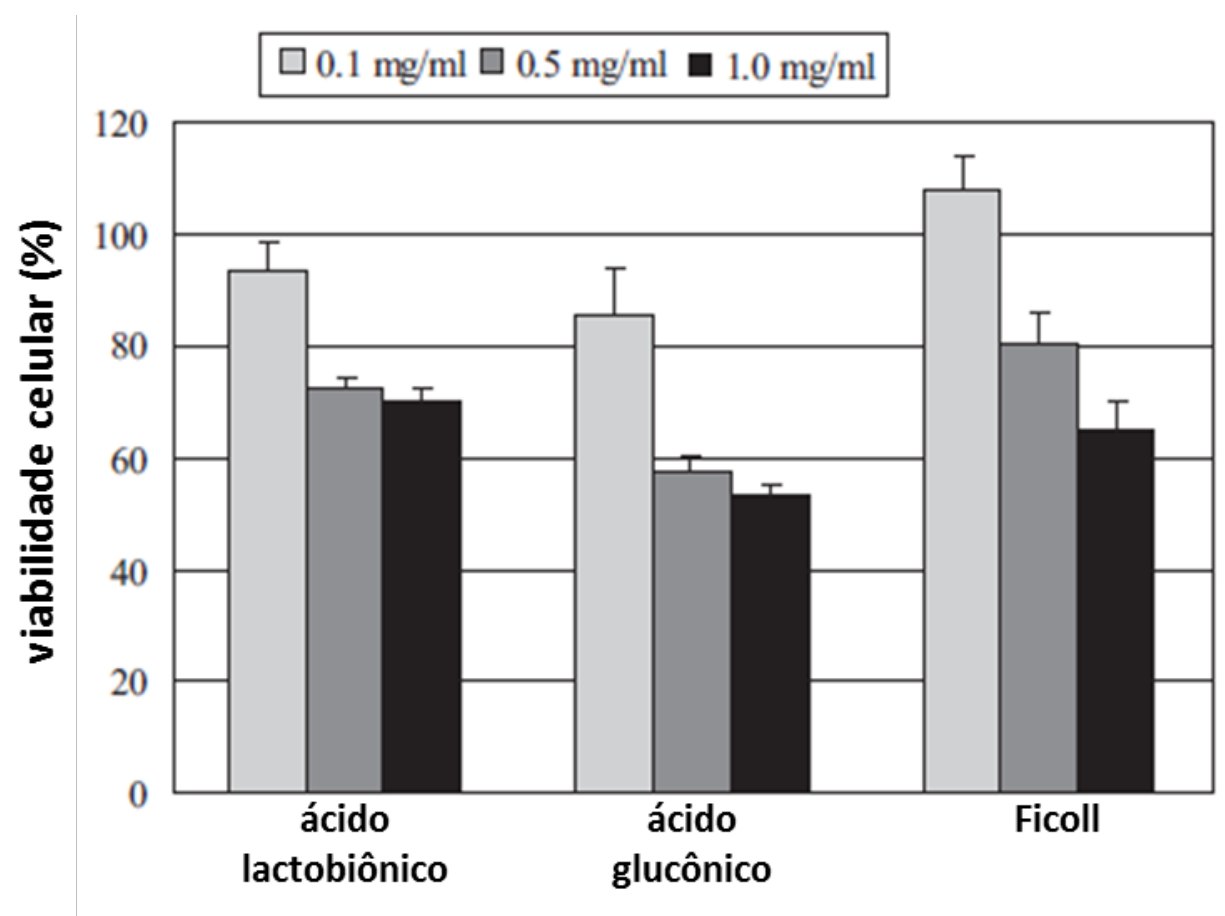

Figura 10 - Viabilidade celular relativa em função da concentração de gliconanopartículas magnéticas com diferentes moléculas funcionalizantes.

Mais recentemente, um estudo espectroscópico mais aprofundado, por FTIR e Raman, foi utilizado para caracterizar a interação do ácido glucônico com nanopartículas de magnetita e de maguemita, para produzir NPMs com alta solubitidade em água [42]. Os autores propuseram diferentes modos de coordenação do ácido glucônico, com os átomos de ferro superficiais, em função do $\mathrm{pH}$, e que é diferenciada em meios alcalinos e ácidos, conforme a desprotonação do R-OH (figura 11). 


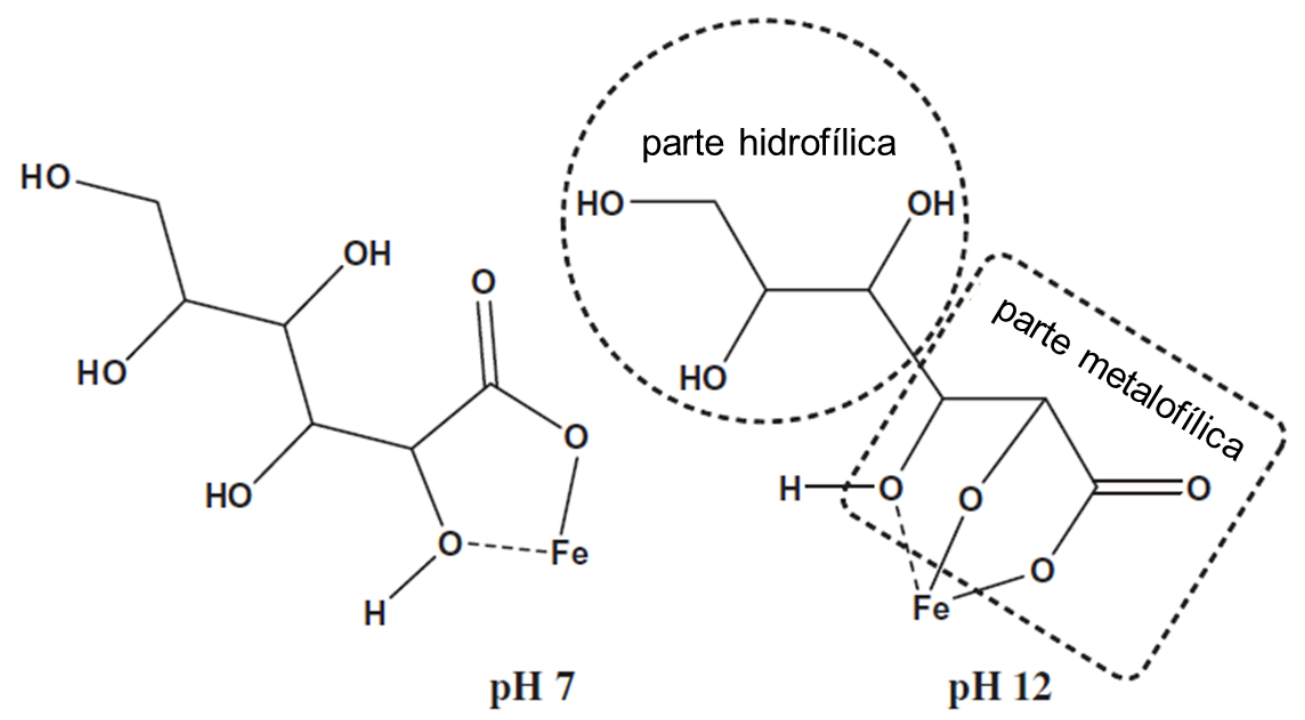

Figura 11 - Modelos de adsorção do ácido glucônico na superfície das NPMs em diferentes pHs. As regiões hidrofílicas e metalofílicas são destacados.

Em outro trabalho, nanopartículas de magnetita foram obtidas por coprecipitação e, em seguida, funcionalizadas com ácido glucônico para otimização da hidrofilicidade e bioafinidade [43]. Nesse sentido, moléculas de lipase foram ligadas às NPMs funcionalizadas, via carbodiimida (EDAC), conforme ilustrado na figura 12. A lipase imobilizada apresentou maior resistência à inativação em função da temperatura e pH, em comparação à forma livre. A estabilidade térmica e armazenabilidade também foram otimizadas. Além disso, a lipase imobilizada ainda apresentou atividade, após inúmeras reciclagens, feitas por separação magnética. 


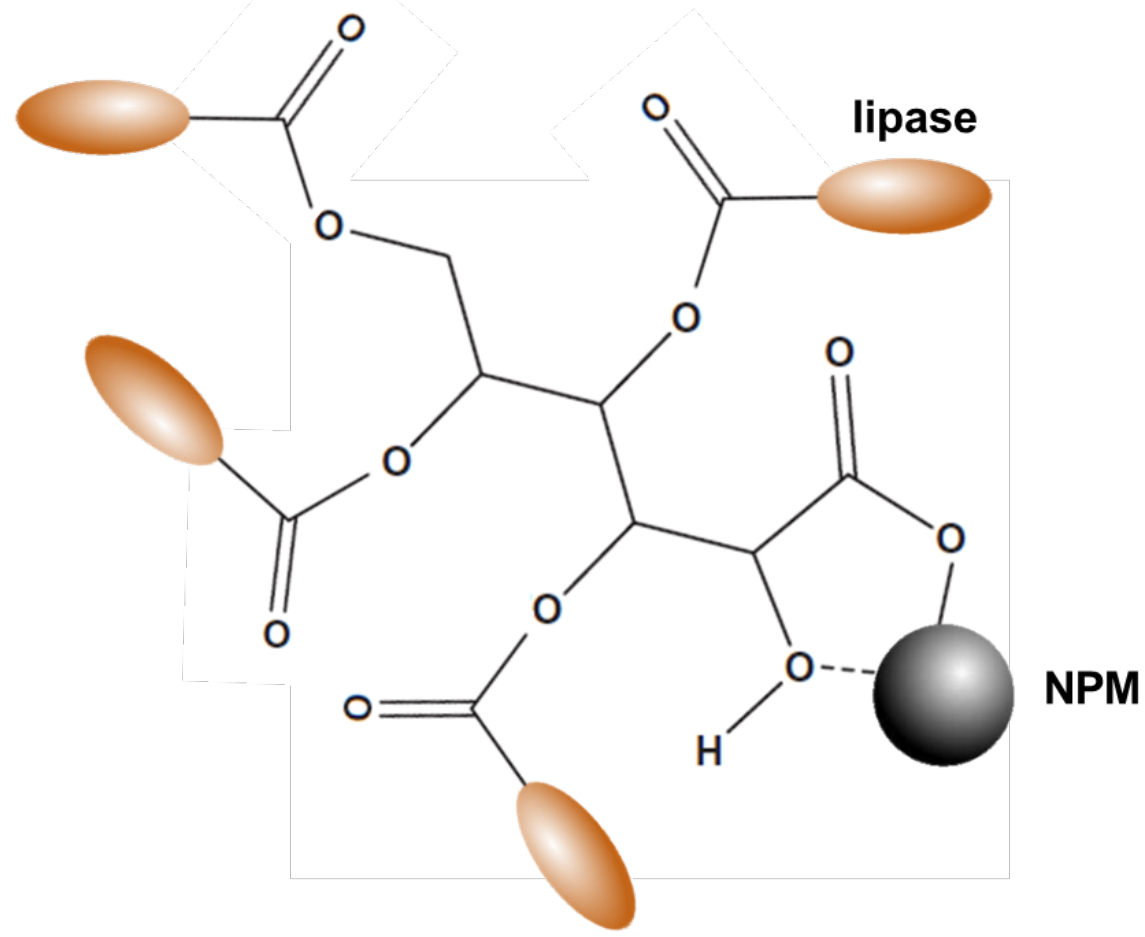

Figura 12 - Modelo de lipases magnéticas elaboradas a partir da adsorção de ácido glucônico à superfície das NPMs e ligação das moléculas de lipase aos grupos hidroxílicos superficiais via cabodiimida EDAC.

Apesar de não ter sido detectada literatura sobre a funcionalização com ácido glicérico, espera-se que o comportamento desse ácido seja parecido com o do ácido glucônico, frente às NPMs, uma vez que têm estruturas bastante similares, salvo que o ácido glicérico apresenta uma cadeia polihidroxílica menor. Além disso, foi possível observar que os trabalhos utilizam exclusivamente magnetita e maguemita, que são óxidos de ferro. Na tentativa de expandir esse estudo, é que se propõe, nesse trabalho, a utilização de NPs de ferrita de cobalto e manganês $\left(\mathrm{Mn}_{1-x} \mathrm{Co}_{x} \mathrm{Fe}_{2} \mathrm{O}_{4}\right)$, que apresenta propriedades magnéticas diferenciadas, como magnetização de saturação mais elevada e valores de campo coercitivo e magnetização remanente diferenciados das NPMs puramente de óxidos de ferro. Outra lacuna que esse estudo focaliza é a determinação simples da concentração do coloide por procedimentos mais simples. Por isso, uma 
metodologia não destrutiva, usando medidas de densidade, foi testada para nanopartículas dispersas em diversos solventes. A partir de diversas investigações, por diferentes técnicas de caracterização, foi possível avaliar que essas NPs funcionalizadas apresentam grande potencial para aplicação, principalmente na área biológica, devido à manipulabilidade magnética e à superfície hidrofílica, em teoria, bastante biocompatível. 


\section{Objetivos}




\section{2- Objetivos}

O objetivo geral desse trabalho foi o de elaborar gliconanopartículas de ferrita mista de manganês e cobalto, funcionalizadas com ácidos carboxílicos polihidroxilados, visando aplicações em nanobiotecnologia.

Como objetivos específicos, se destacam:

- síntese química de NPMs de ferrita $\mathrm{Mn}_{1-x} \mathrm{Co}_{x} \mathrm{Fe}_{2} \mathrm{O}_{4}$ por coprecipitação alcalina;

- dispersão das NPs em meio aquoso para formar FMs iônicos;

- funcionalização das NPs com ácido glucônico e glicérico;

- peptização das NPs em meios aquosos e alcóolicos;

- proposição de metodologia para determinação da concentração do coloide;

- caracterização dos nanomateriais e soluções coloidais em todas as etapas. 
Materiais $e$ métodos 


\section{3- Materiais e métodos}

A metodologia desse trabalho, conforme esquematizado na figura 13, é dividida em elaboração das amostras e caracterização dos nanomateriais produzidos.

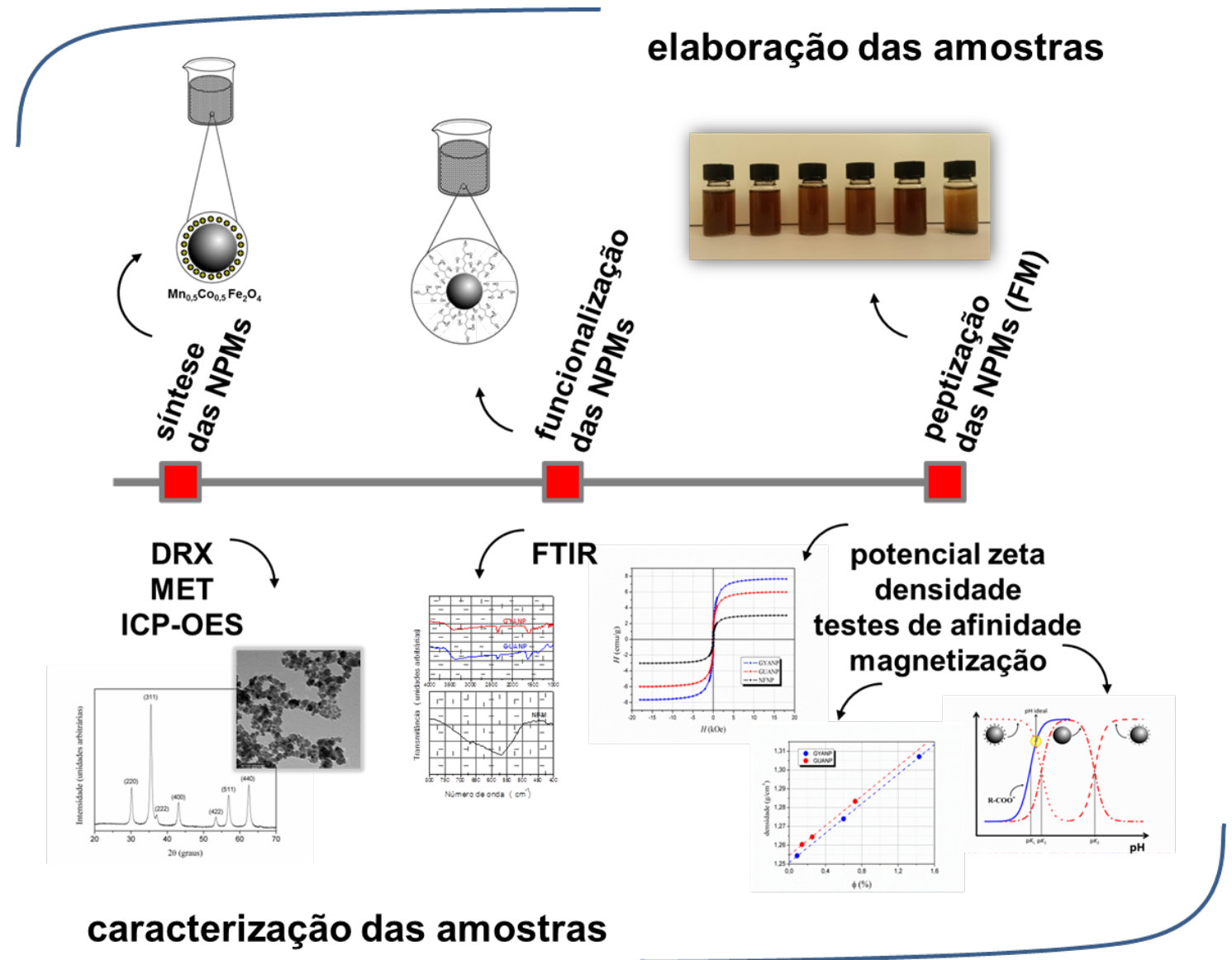

Figura 13 - Esquema, destacando as principais etapas de preparação e da caracterização das amostras de fluidos magnéticos e nanopartículas utilizados nesse trabalho.

O preparo das amostras envolve a síntese das NPMs, a funcionalização com os ligantes escolhidos e a peptização em diferentes meios para obtenção dos fluidos magnéticos. A estrutura e o tamanho cristalino das NPMs foram produzidas e caracterizados por difratometria de raios X (DRX), a morfologia e a distribuição em tamanho dessas NPs foram determinadas por microscopia eletrônica de transmissão 
(MET) e a composição química dos materiais foi estudada por espectroscopia de emissão atômica por plasma indutivamente acoplado (ICP-OES). A eficiência da funcionalização foi investigada por espectroscopia de absorção no infravermelho com transformada de Fourrier (FTIR). Um modelo para determinação da concentração dos coloides preparados foi proposto, a partir de medidas de densidade dos fluidos magnéticos que, também, tiveram as propriedades magnéticas e de potencial eletrocinético (potencial zeta) investigadas.

\subsection{Elaboração das amostras}

Conforme mencionado e melhor representado na figura 14, a elaboração das amostras começa com a síntese química das nanopartículas magnéticas da ferrita mista de cobalto e manganês, $\mathrm{Mn}_{1-x} \mathrm{Co}_{x} \mathrm{Fe}_{2} \mathrm{O}_{4}$. Visando a composição $\mathrm{Mn}_{0,5} \mathrm{Co}_{0,5} \mathrm{Fe}_{2} \mathrm{O}_{4}$, $50 \mathrm{mmol}$ de $\mathrm{Co}^{2+}$, $50 \mathrm{mmol}$ de $\mathrm{Mn}^{2+} 200 \mathrm{mmol} \mathrm{de} \mathrm{Fe}^{3+}$, todos na forma de cloretos hexahidratados, foram dissolvidos em $300 \mathrm{~mL}$ de $\mathrm{HCl} 0,5 \mathrm{~mol} / \mathrm{L}$ e a solução foi aquecida até atingir cerca de $90^{\circ} \mathrm{C}$. Em outro recipiente, $2 \mathrm{~L}$ de $\mathrm{NaOH} 1 \mathrm{~mol} / \mathrm{L}$ foram aquecidos até a ebulição, sob constante e vigorosa agitação. Em seguida, o a solução de metais foi vertida no recipiente contendo o $\mathrm{NaOH}$ e o sistema ficou sob agitação e ebulição por 120 min. Depois desse tempo, o precipitado magnético obtido foi lavado 3 vezes com água, separado por decantação magnética. Após descartar o sobrenadante, o precipitado foi lavado com uma solução $1 \mathrm{~mol} / \mathrm{L}$ de ácido nítrico, por $30 \mathrm{~min}$ e, em seguida, o sobrenadante foi descartado. Após essa etapa, o sólido magnético foi disperso em uma solução de nitrato férrico $1 \mathrm{~mol} / \mathrm{L}$ e essa suspensão foi aquecida até $95{ }^{\circ} \mathrm{C}$, sob agitação, por 30 min. Finalmente, o sobrenadante foi descartado, o precipitado foi 
lavado com acetona e, após evaporação desse solvente, foi redisperso em aproximadamente $100 \mathrm{~mL}$ de uma solução diluída de $\mathrm{HNO}_{3}$.

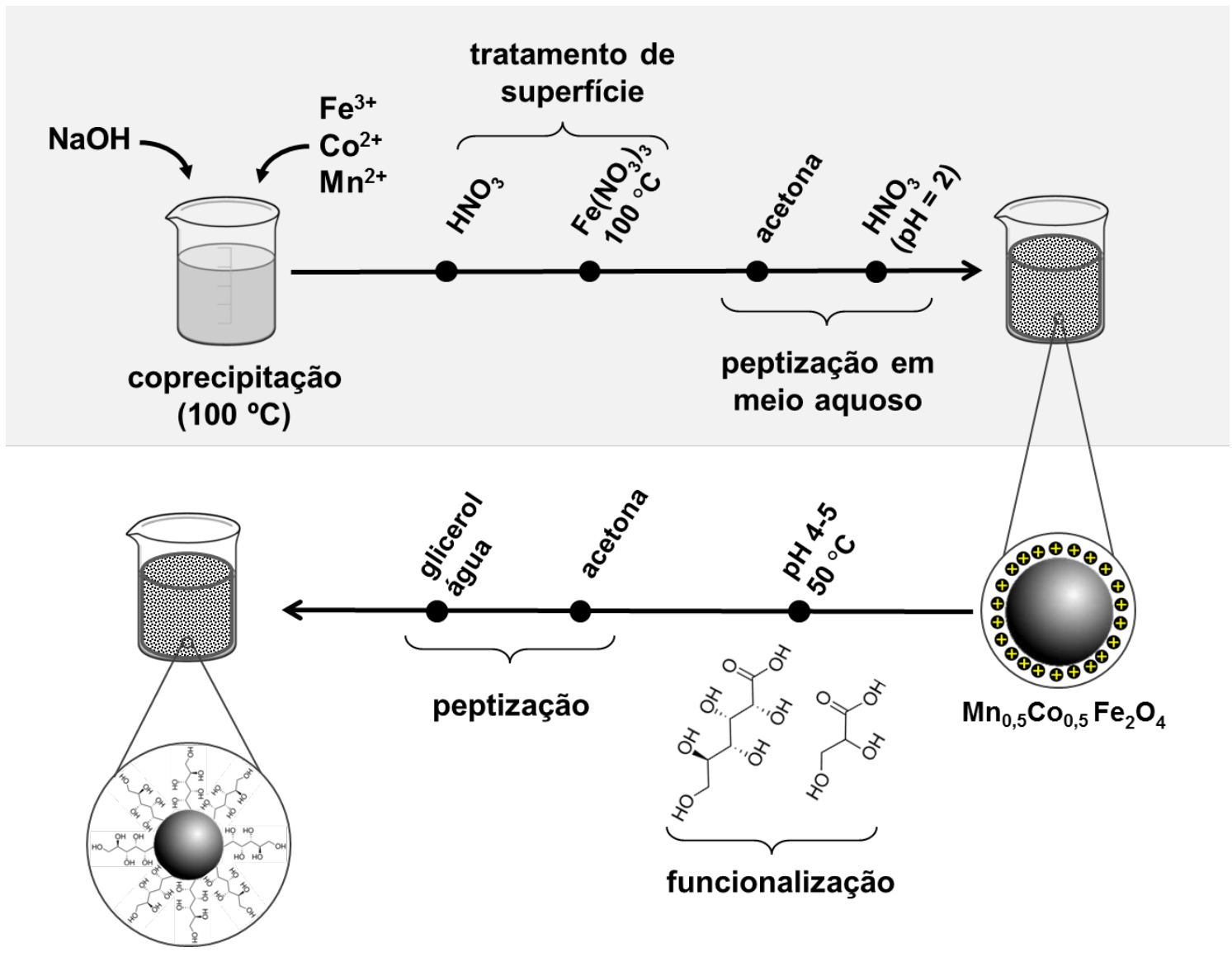

Figura 14 - Detalhamento esquemático das etapas envolvidas na síntese e funcionalização das NPMs, bem como da dispersão das mesmas para formar FMs.

Após sintetizadas e dispersas na forma de um fluido magnético iônico com $\mathrm{pH}$ aproximadamente 2, as NPs foram, então, funcionalizadas. Para tal, $5 \mathrm{~mL}$ do FM anteriormente preparado, a uma concentração de $380 \mathrm{mg}$ de $\mathrm{NP} / \mathrm{mL}$ de fluido foram diluídos a $10 \mathrm{~mL}$ com água e, a essa dispersão, $10 \mathrm{mmol}$ do ligante (ácido glicérico ou ácido glucônico) foram adicionados. A pós ajustar o $\mathrm{pH}$ para um valor 4 e 5, conforme discutido na próxima seção, a mistura ficou, sob agitação e a $50^{\circ} \mathrm{C}$, por 60 min. Após esse tempo, o excesso de ligante não adsorvido foi removido por sucessivas lavagens 
com água e acetona e, após remoção do sobrenadante e evaporação do solvente, as NPMs funcionalizadas foram dispersas em cerca de $10 \mathrm{~mL}$ de água ou glicerol.

\subsection{Caracterização das amostras}

\subsubsection{Microscopia eletrônica de transmissão (MET)}

As partículas magnéticas que compõem os fluidos magnéticos aqui preparados possuem dimensões coloidais, inferiores a $100 \mathrm{~nm}$. Um sistema convencional de microscopia ótica não tem poder de resolução nesta faixa de dimensões, já que é limitado pelo comprimento de onda da luz visível utilizada no aparelho. Para contornar essa situação, dentre as microscopias de maior resolução, a MET é a mais adequada [44]. Um dos aspectos dessa técnica é a possibilidade de se obter imagens diretas das partículas que compõem os sistemas em estudo - uma contagem em função dos diâmetros permite gerar um histograma para as partículas, e a partir daí, por meio de um ajuste com uma função matemática, calcular o diâmetro das partículas, bem como a sua dispersão em tamanho. A função matemática que melhor representa essa distribuição é uma função $\log$-normal dada por $P(D)=\frac{1}{D \sigma^{e m} \sqrt{2 \pi}} \exp \left[-\frac{\ln ^{2}\left(D / D_{0}^{e m}\right)}{2 \sigma^{e m} 2}\right]$, em que $\ln D_{0}^{e m}=\langle\ln D\rangle$ e $\sigma^{e m}$ é o desvio padrão. Isso leva ao diâmetro mais provável, $D_{m p}^{e m}=D_{0}^{e m} \exp \left[-\left(\sigma^{e m}\right)^{2}\right]$ e a um diâmetro médio $\left\langle D^{e m}\right\rangle=D_{0}^{e m} \exp \left[0,5\left(\sigma^{e m}\right)^{2}\right]$. 
Para análise por TEM, os FMs preparados foram diluídos em água e, em seguida, $5 \mu \mathrm{L}$ da amostra foram depositados em uma tela de cobre recoberta com carbono e com um filme de Formvar ${ }^{\circledR}$. Após secarem por $24 \mathrm{~h}$ em dessecador, as amostras foram analisadas em um microscópio JEOL, modelo 1011, no Instituto de Biologia da Universidade de Brasília. Os histogramas foram construídos a partir da contagem de cerca de 500 partículas e tratados com o programa ImageJ.

\subsubsection{Difração de raios X (DRX)}

A técnica de difração de raios $\mathrm{X}$ fornece resultados estruturais indispensáveis em se tratando do estudo de materiais cristalinos [45]. A partir de difratogramas obtidos é possível identificar a estrutura cristalina de um material, utilizando-se a relação de Bragg, $2 d_{h k l} \operatorname{sen} \theta=n \lambda$, em que $d_{h k l}$, é a distância interplanar, $\lambda$ é o comprimento de onda da radiação, $\theta$ é o ângulo de difração e $n$ é a ordem de difração. Além disso, no caso de amostras policristalinas, é possível estimar a dimensão característica das partículas, utilizando-se o formalismo de Scherrer, $D_{R X}=\frac{0,9 \lambda}{B \cos \theta}$, em que $B$ é a largura à meia altura do pico de maior intensidade, registrado no difratograma.

Os dados de difração de pó podem ser tratados por um método ponto a ponto: a intensidade é medida durante um dado intervalo de tempo para determinado valor do ângulo de difração 2 $\theta$. A partir disso, os índices de Miller são associados com as reflexões observadas e simultaneamente é calculada a dimensão da célula unitária. Por causa da impossibilidade de se obter erros experimentais na estimativa do ângulo de difração e por causa da frequente sobreposição das intensidades dos picos, indexar é 
uma tarefa um tanto difícil. Entretanto, vários métodos, que utilizam programas de computadores proporcionam uma solução. Se um modelo estrutural, até mesmo imperfeito é possível, então a intensidade observada no i-ésimo passo pode ser comparada com a correspondente intensidade calculada pelo modelo. De acordo com modelo de Rietveld [46], os dados podem ser refinados pela minimização da soma dos quadrados dos desvios. A intensidade calculada é a soma das contribuições associadas às reflexões de Bragg e da linha de base e os parâmetros a serem ajustados pelo método incluem: dimensão da célula, posição dos átomos e parâmetros térmicos. A determinação da precisão do modelo para o perfil da função reflexão é um dos fundamentais problemas no Refinamento de Rietveld. A forma do pico de difração depende de vários parâmetros: a fonte de radiação, a distribuição do comprimento de onda do feixe primário, o feixe característico (como influência da fenda e do colimador entre a fonte de radiação primária e o monocromador, entre o monocromador e a amostra e entre a amostra e o detector), e o sistema de detecção. Para isso, existem muitas escolhas para a função de linha da forma do pico. Por exemplo, Gaussiana, Lorentziana, pseudo-Voigt, Pearson VII. Não existem aproximações bem definidas para a função de background. Isso é principalmente devido à varredura e ruídos eletrônicos do sistema de detecção. A análise do perfil da figura de difração alargada é frequentemente usada para se refinar a posição dos picos e a altura para cada reflexão: a partir disso, o parâmetro de rede é calculado e refinado. Picos gerados pela sobreposição de mais reflexões são somados e a intensidade individual correspondente a uma reflexão hkl é calculada, junto com o seu desvio padrão e suas correlações.

Para análise por DRX, as amostras de FM foram lavadas com acetona e secas em estufa a $45{ }^{\circ} \mathrm{C}$. O pó obtido foi triturado e finamente pulverizado com auxílio de um graal de ágata e prensados em um porta-amostras de vidro. Em seguida foram analisadas 
em um difratômetro Miniflex 600, Rigaku, com detecção rápida DTex, operando a 40 $\mathrm{kV}, 30 \mathrm{~mA}$ e radiação $\mathrm{Cu}-K \alpha$, selecionada com um monocromador de grafite. As condições de varredura foram de 20 a $70^{\circ}$, com um passo de $0,02^{\circ}$ e velocidade de $5 \%$ min. Os dados obtidos foram tratados conforme descrito na referência [47], com auxílio do programa GSAS.

\subsubsection{Espectroscopia de emissão atômica por plasma indutivamente acoplado (ICP-OES)}

Para análise da composição química das nanopartículas, as amostras de FMs foram devidamente diluídas com água e analisadas pela introdução direta do coloide no espectrômetro ICP Optima 8000DV, Perkin Elmer, com modo de emissão óptica. As condições experimentais, bem como a faixa de concentração utilizada, estão descritas na referência [48].

\subsubsection{Espectroscopia de absorção no infravermelho com transformada de Fourrier (FTIR)}

As amostras das NPs não funcionalizadas e das funcionalizadas, bem como dos ácidos glicérico e glucônico foram devidamente pulverizadas e maceradas com $\mathrm{KBr}$ puro e seco e, em seguida, prensados para formar pastilhas a serem analisadas espectrofotômetro Bruker, modelo Vertex-70, com resolução de $2 \mathrm{~cm}^{-1}$, via análise 
média de 32 scans, em modo de transmissão. Os espectros de infravermelho, para todas as amostras, foram obtidos na região de $4000-400 \mathrm{~cm}^{-1}$.

\subsubsection{Medidas de densidade}

Para determinação da densidade das amostras de FMs, um densímetro digital DMA 4500 M (Anton Paar), cuja medição se baseia no princípio de tubo em U oscilante assegurando valores de densidade altamente exatos, foi utilizado. As amostras foram diluídas em série, utilizando o solvente adequado, e a densidade foi registrada à temperatura constante de $25{ }^{\circ} \mathrm{C}$, com auxílio do controlador de temperatura do equipamento.

\subsubsection{Medidas de potencial zeta (potencial eletrocinético)}

O potencial zeta das nanopartículas foi determinado, indiretamente, por espectroscopia de espalhamento de luz dinâmico com um analisador de partículas Zetasizer nano ZS (Malvern Instruments), usando células especiais de polietileno. As soluções foram submetidas ao espalhamento de luz monocromática $(10 \mathrm{~mW} H e-\mathrm{Ne}$ laser, $\lambda=632,4 \mathrm{~nm}$ ) com ângulo de espalhamento de $173^{\circ}$. Os resultados das medidas foram obtidos a partir de 20 scans com 10 segundos de intervalo. Pelo menos 3 medidas foram feitas para cada amostra, e os resultados foram expressos como uma média aritmética dos dados obtidos. Os FMs foram diluídos de 100 a 1000 vezes em água e o pH ajustado ao valor desejado com auxílio de soluções de $\mathrm{HCl}$ ou $\mathrm{NaOH}$. 


\subsubsection{Medidas de magnetização}

A Magnetometria de Amostra Vibrante, ou VSM (Vibrating Sample Magnetometer) foi desenvolvida por Foner em 1955 e é atualmente uma das técnicas mais utilizadas, não só por ser relativamente sensível (sensibilidade da ordemde $10^{-5}$ emu), mas também por seu funcionamento simples e baixo custo de manutenção. A técnica fornece informações sobre as propriedades magnéticas da amostra por meio da curva de histerese, e se baseia na obtenção de magnetização por indução [49]. O VSM consiste em uma haste rígida fixa a um vibrador (um alto-falante). A amostra deve ser colocada na outra extremidade da haste e posicionada entre dois eletroímãs e um conjunto de bobinas detectoras. Para se obter o sinal da magnetização, faz-se vibrar a amostra perpendicularmente ao campo aplicado que, ao oscilar, produz uma variação do fluxo de campo magnético local, gerando uma corrente induzida alternada nas bobinas detectoras posicionadas em torno da amostra. Desta forma é registrada a intensidade do momento magnético da amostra.

Sem prévia diluição, as amostras de FMs magnéticos e os pós dessas amostras, obtidos por lavagem com acetona e secagem em estufa, foram analisados em magnetômetro VSM, em uma faixa de campo magnético, de $-18 \mathrm{kOe}$ a $+18 \mathrm{kOe}$, a $25^{\circ} \mathrm{C}$. 
Resultados e discussão 


\section{Resulstados e discussão}

\subsection{Síntese de NPMs e elaboração de FM iônico em meio aquoso}

Após execução da primeira parte do procedimento de síntese descrito na parte experimental, um precipitado escuro foi obtido e pôde ser facilmente separado com auxílio de um ímã, conforme mostrado na foto da figura 15, que ilustra as várias etapas de síntese do fluido magnético que serviu como base para o preparo das subsequentes amostras e para algumas caracterizações desse trabalho.

A reação que representa a formação do material em questão pode ser condensada na equação 1 , abaixo, em que $0 \leq x \leq 1$ (em mol):

$$
x \mathrm{Co}^{2+}+(1-x) \mathrm{Mn}^{2+}+2 \mathrm{Fe}^{2+}+8 \mathrm{OH}^{-} \rightarrow \mathrm{Mn}_{1-x} \mathrm{Co}_{x} \mathrm{Fe}_{2} \mathrm{O}_{4}+4 \mathrm{H}_{2} \mathrm{O}
$$

Nesse caso, espera-se que $x=0,5 \mathrm{~mol}$, que foi o valor de partida para os reagentes, no início da síntese.

Em seguida, o precipitado foi lavado três vezes com água, a fim de se retirar o excesso de íons da base utilizada na síntese - particularmente, o $\mathrm{Na}^{+}$proveniente do $\mathrm{NaOH}$ é um íon polarizante que pode induzir a coagulação dos coloides. O ideal é que os contra-íons, em um sol, sejam mais volumosos, como é o caso dos ânions nitrato $\left(\mathrm{NO}_{3}{ }^{-}\right)$, perclorato $\left(\mathrm{ClO}_{4}{ }^{-}\right)$e do cátion tetrametilamônio $\left(\mathrm{H}_{3} \mathrm{C}\right) \mathrm{N}^{+}$, muito utilizados na preparação de fluidos magnéticos [50]. 

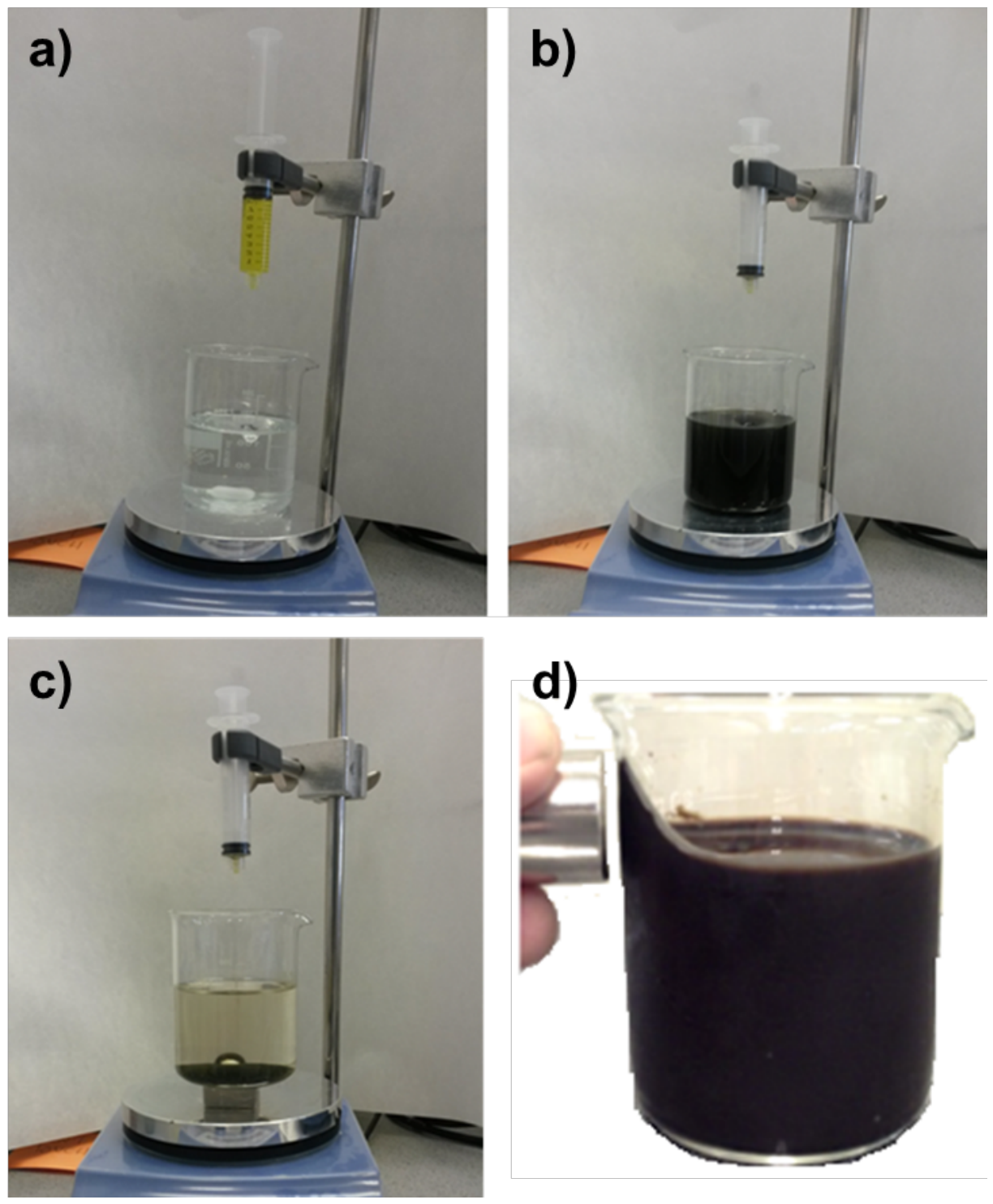

Figura 15 - As várias etapas na síntese de um FM iônico: frasco de reação antes (a) e após (b) a mistura de metais contida na solução da seringa com o NaOH contido no béquer; c) separação magnética do precipitado obtido, após 30 min de síntese e; d) fluido magnético obtido após tratamento de superfície e peptização das NPs.

No caso dos óxidos magnéticos, mesmo sem funcionalizar a superfície das nanopartículas e com devido controle da força iônica do meio, é possível se preparar sóis estáveis em meios ácidos ou básicos - mas nunca em meios neutros - pelo simples controle de pH. Nesse modelo, em que os fluidos magnéticos são chamados de iônicos, ou com dupla camada elétrica, a estabilização do coloide é via repulsão eletrostática 
entre as partículas e, microscopicamente, os metais, na superfície das NPs (principalmente o ferro), podem estar coordenados a diferentes espécies, conforme representado no esquema da figura 16. Em pHs mais ácidos (básicos), as nanopartículas são positivamente (negativamente) carregadas [51]. Nesse caso, se considera que os sítios superficiais das nanopartículas (D) possam sofrer hidrólises, de acordo com as reações ácido-base mostradas nas equações 2 e 3.

$$
\begin{gathered}
\text { D- } \mathrm{OH}_{2}^{+}+\mathrm{H}_{2} \mathrm{O} \leftrightarrows \text { - }-\mathrm{OH}+\mathrm{H}_{3} \mathrm{O}^{+} \\
\text {D- } \mathrm{OH}+\mathrm{H}_{2} \mathrm{O} \leftrightarrows \mathbf{D}-\mathrm{O}^{-}+\mathrm{H}_{3} \mathrm{O}^{+}
\end{gathered}
$$

Nesse modelo, a superfície da nanopartículas comporta-se como um ácido diprótico, o que gera os três tipos de sítios superficiais, D- $\mathrm{OH}_{2}{ }^{+}$predominante em meio ácido, - $\mathrm{O}^{-}$em meio básico e $-\mathrm{OH}$, a espécie anfotérica, no ponto isoelétrico (IEP), situada entre os dois $\mathrm{p} K_{\mathrm{a}} \mathrm{s}$ da superfície. Quantitativamente, quando $\mathrm{pH}=\mathrm{p} K_{1}, \mathbf{D}-\mathrm{OH}_{2}^{+}$ e D- $\mathrm{OH}$ são equimolares e se $\mathrm{pH}=\mathrm{p} K_{2},[\mathbf{D}-\mathrm{OH}]=\left[\mathbf{D}-\mathrm{O}^{-}\right]$. No IEP, a concentração de D-OH atinge seu máximo. 


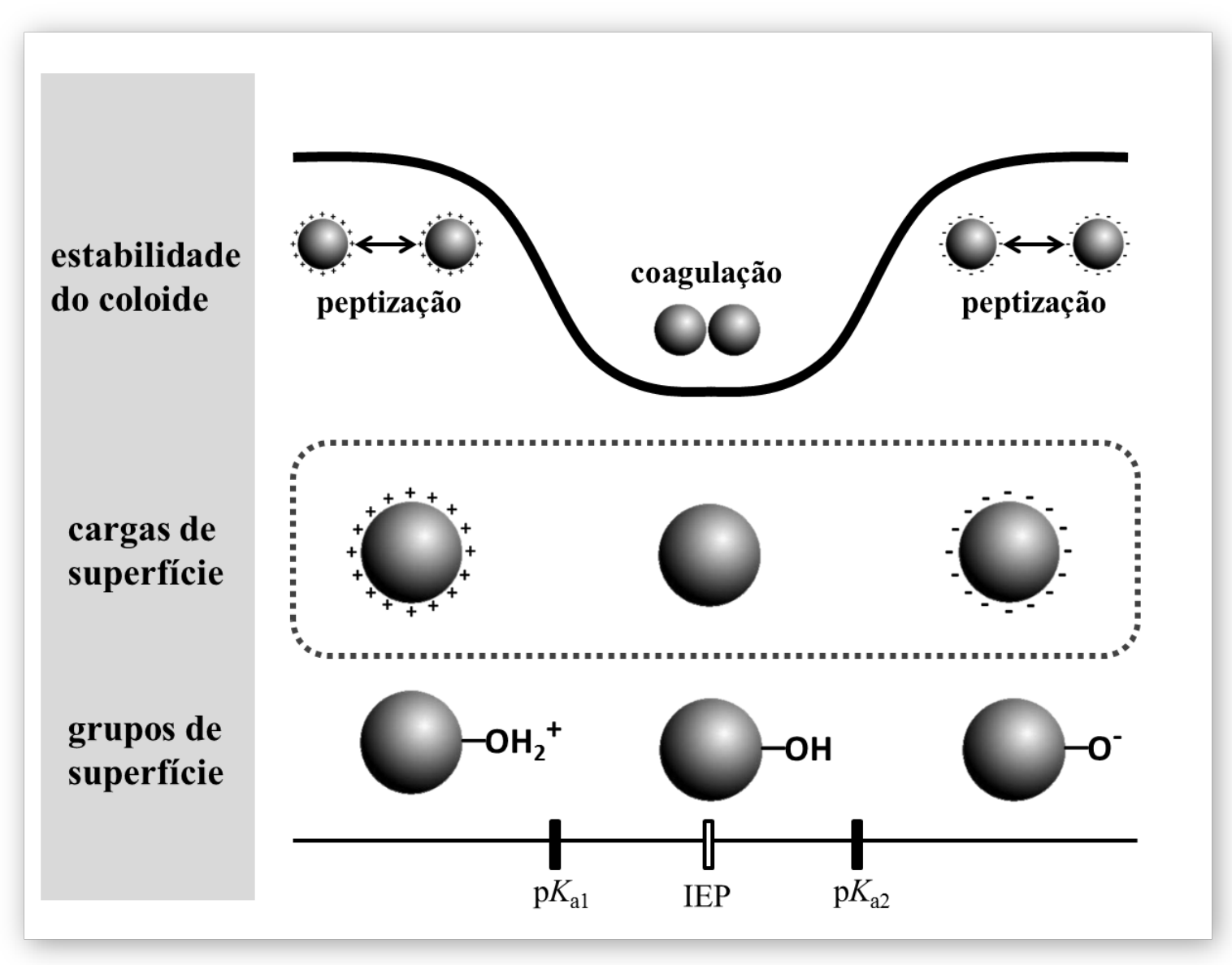

Figura 16 - Diagrama esquemático representando a estabilidade coloidal, as cargas de superfície e os grupos associados a essas cargas, em função do $\mathrm{pH}$. $\mathrm{p} K_{\mathrm{a} 1}$ e $\mathrm{p} K_{\mathrm{a} 1}$ representam os valores das constantes de dissociação ácida dos grupos de superfície e IEP representa o ponto isoelétrico, em $\mathrm{pH} \sim 7$ para as NPMs aqui estudadas.

Para elaboração do fluido magnético em meio aquoso, escolheu-se o meio ácido, uma vez que em meio básico a estabilidade pode ser comprometida durante o manuseio da amostra, que reage com o $\mathrm{CO}_{2}$ do ar e diminui seu $\mathrm{pH}$ para a região do IEP, de coagulação coloide. Nesse caso, a amostra foi lavada com uma solução diluída de ácido nítrico para baixar o $\mathrm{pH}$ e estabelecer o $\mathrm{NO}_{3}{ }^{-}$como contra-íon. Entretanto, antes de peptizar as nanopartículas, um tratamento hidrotérmico com nitrato férrico foi feito para aumentar a estabilidade físico-química do material contra a dissolução em meio ácido [52]. Nesse tratamento, uma camada de um óxido/hidróxido de ferro é depositada 
na superfície, mas pela similaridade de estrutura com o núcleo de ferrita, não altera as características de sítios superficiais. Dessa forma, após extração do excesso de $\mathrm{Fe}\left(\mathrm{NO}_{3}\right)_{3}$ não reagido, pela lavagem sucessiva do precipitado com acetona, evaporação do resíduo desse solvente por evaporação e reposição de água, um sol estável em $\mathrm{pH} \sim 2$ pôde ser obtido. A amostra foi então armazenada e parte foi utilizada para caracterização e preparação das amostras funcionalizadas e dispersas em outros solventes.

\subsection{Caracterização química, morfológica e estrutural das nanopartículas}

Com a finalidade de investigar a morfologia e a distribuição em tamanho das estruturas presentes no precipitado, uma alíquota da amostra elaborada foi devidamente diluída e analisada por microscopia eletrônica de transmissão. Uma das fotos típicas para essa amostra é ilustrada na figura 17. Como pode ser observado, nanopartículas com formas aproximadamente esféricas foram obtidas, em consonância com o tipo de material que o método de coprecipitação, nessas condições, é capaz de render.

A análise estatística, utilizando o modelo log-normal de distribuição (ver detalhes na parte de metodologia) permitiu, a partir da determinação do diâmetro de aproximadamente 500 partículas, traçar o histograma que é mostrado na figura 18. A partir do ajuste dos dados, o diâmetro médio para as nanopartículas foi de $15,2 \mathrm{~nm}$ e a polidispersão igual a 0,35 . 


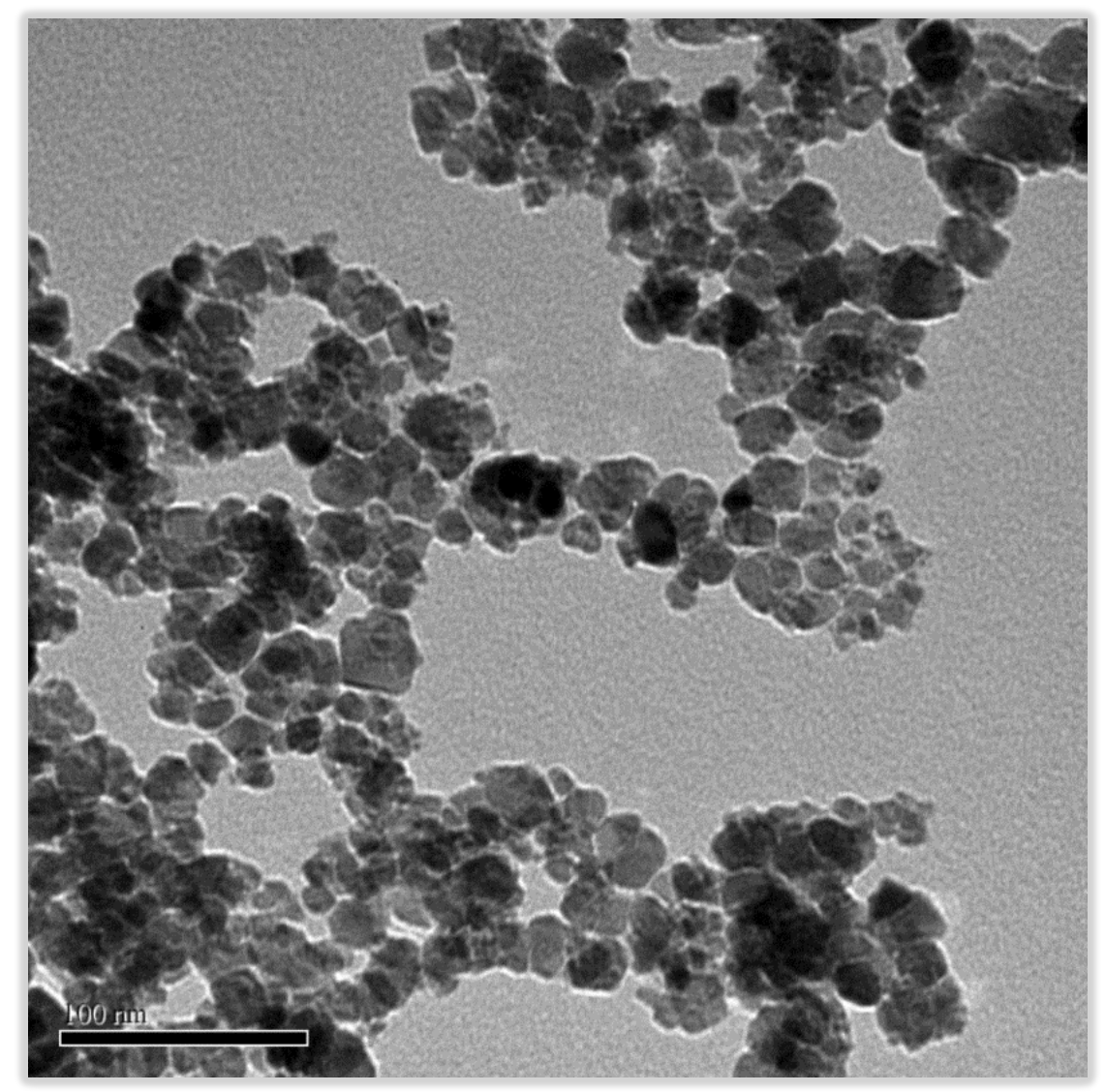

Figura 17 - Imagem obtida por TEM para a amostra de FM iônico.

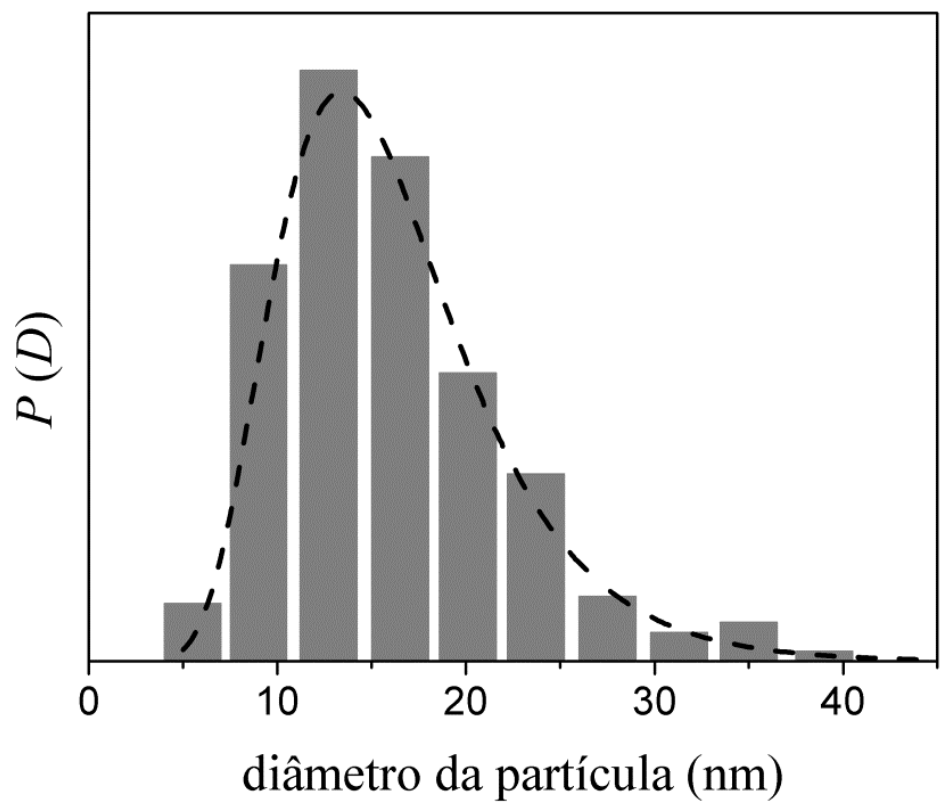

Figura 18 - Histograma de distribuição em tamanho obtido a partir da contagem da frequência das NPs em função do diâmetro (via programa ImageJ). 
Com a finalidade de investigar a estrutura cristalográfica e o diâmetro cristalino das nanopartículas, uma amostra do fluido magnético foi seca em estufa a $50{ }^{\circ} \mathrm{C}$ e uma análise por difratometria de raios $\mathrm{X}$ foi realizada no pó obtido. Os dados dessa análise estão plotados na forma de um difratograma, da intensidade difratada versus o ângulo de difração, na figura 19. Após comparação com padrões ASTM, foi possível identificar uma única fase cristalina que corresponde à estrutura do tipo espinélio - os principais picos de difração estão devidamente indexados no gráfico.

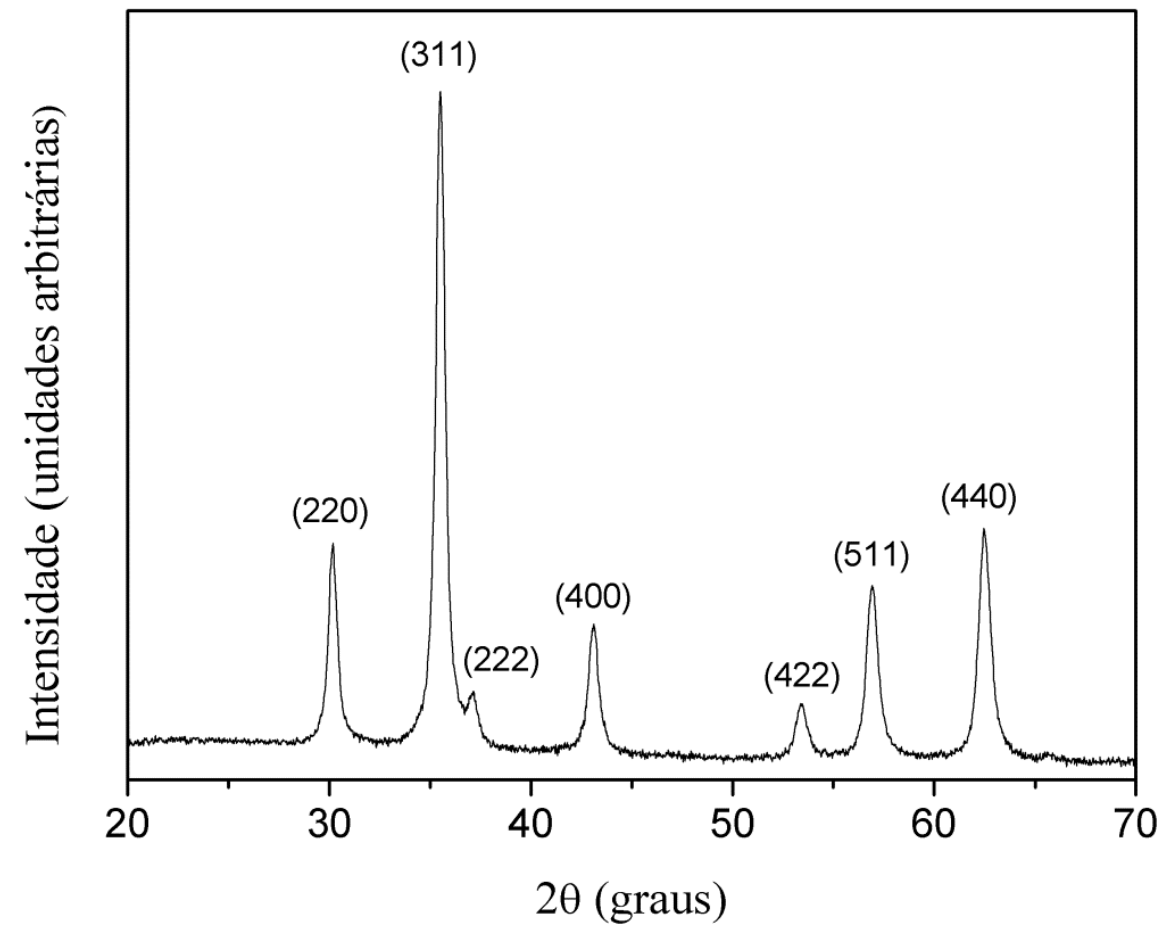

Figura 19 - Difratograma de raios X obtido para as nanopartículas sintetizadas.

Para análise quantitativa, foi realizado um ajuste dos dados utilizando o método de Rietveld (ver detalhes na parte experimental). O difratograma ajustado é mostrado na figura 20 e os resultados de refinamento (dependência angular da intensidade espalhada calculada) são listados na tabela 1 . Nessa tabela, u é a posição do oxigênio, $a$ é o 
tamanho da malha cúbica. Ainda, a tabela apresenta o valor calculado para a densidade das nanopartículas, para o diâmetro médio, bem como o fator de qualidade do ajuste $\chi^{2}$ e os fatores residuais $R_{\mathrm{p}}$ e $R_{\mathrm{wp}}$ relacionados com a confiabilidade ou precisão do refinamento.

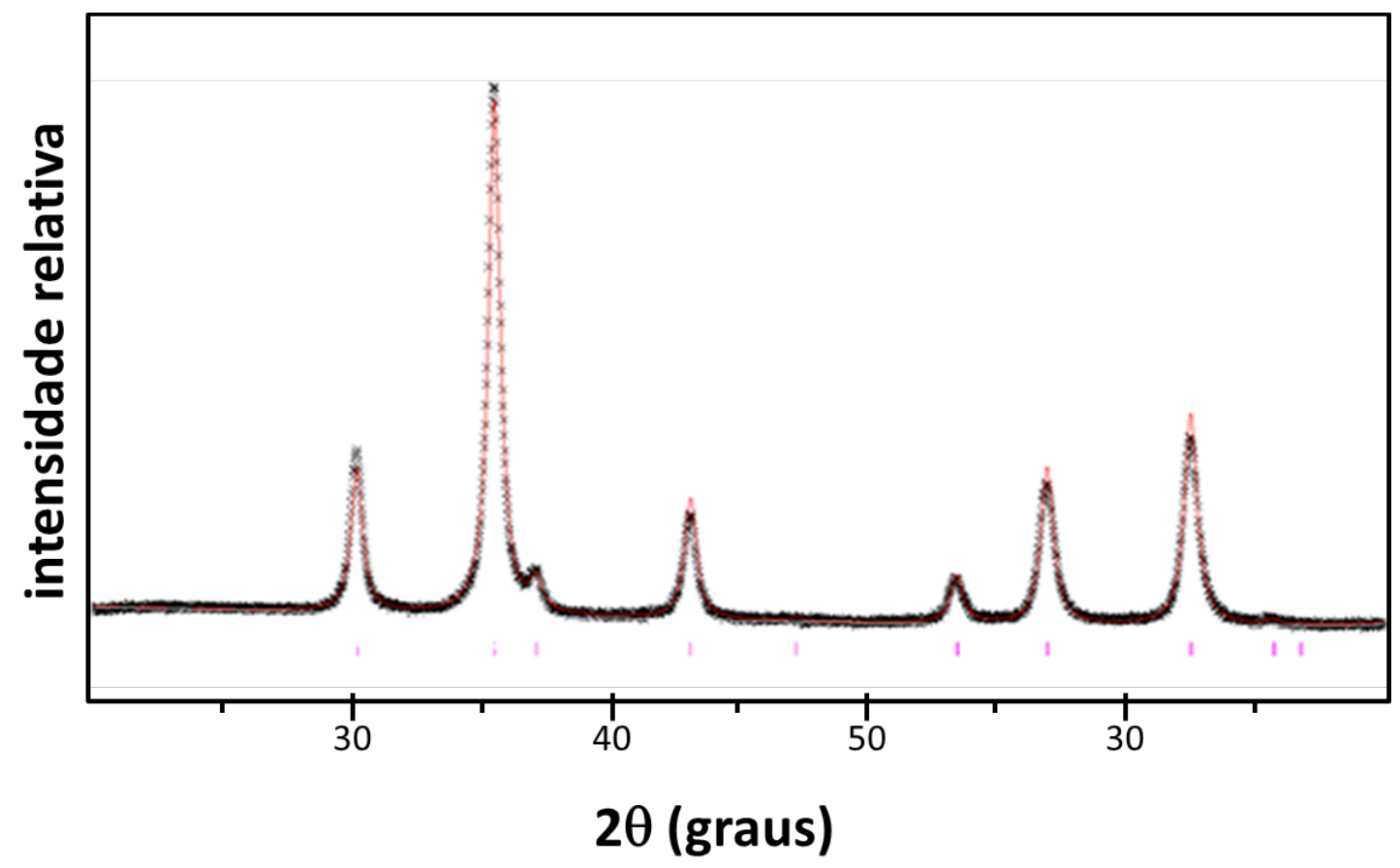

Figura 20. Difratograma mostrando os dados experimentais (pontos) e o ajuste teórico e a análise de erro utilizando o método de Rietveld (linha).

$\mathrm{O}$ valor do fator de qualidade, inferior a 2,5 , mostra a boa qualidade do ajuste obtido, já que o $\chi^{2}$ tende a 1 , no caso ideal. Os fatores residuais, todos inferiores a $5 \%$, indicam também uma boa precisão do ajuste obtido. Com relação ao valor do parâmetro de malha, o valor de $8,425 \AA$, intermediário aos valores para as ferritas de cobalto $(8,33$ Å) e manganês $(8,49 \AA ̊)$ ideais, indica o caráter misto da estrutura. 


\begin{tabular}{|c|c|c|c|}
\hline \multicolumn{2}{|c|}{$\left(\mathrm{Co}_{x} \mathrm{Mn}_{y}\right) \mathrm{Fe}_{2} \mathrm{O}_{4}$} & $a$ & 0,8425 \\
\hline $\begin{array}{l}\text { Co } \\
(x)\end{array}$ & 0.5 & $\mathrm{U}$ & 0.2548 \\
\hline $\begin{array}{l}\mathrm{Mn} \\
(y)\end{array}$ & 0.5 & $\begin{array}{l}R_{\mathrm{wp}} \\
(\%)\end{array}$ & 2.30 \\
\hline $\begin{array}{c}\text { densidade } \\
\left(\mathrm{g} / \mathrm{cm}^{3}\right)\end{array}$ & 5.167 & $\begin{array}{c}R_{\mathrm{p}} \\
(\%)\end{array}$ & 1.73 \\
\hline $\begin{array}{l}\text { diâmetro } \\
\text { (nm) }\end{array}$ & 17,2 & $x^{2}$ & 2.229 \\
\hline
\end{tabular}

Tabela 1 - Parâmetros refinados, fatores de qualidade e residuais.

É possível observar que o diâmetro médio encontrado é igual a $17,2 \mathrm{~nm}$, um pouco maior que o diâmetro obtido por TEM. Isso se deve ao fato de que o diâmetro obtido por XRD não leva em conta eventuais partes pouco cristalinas das nanopartículas e que, na contagem de partículas para plotagem do histograma, partículas maiores em agregados não são consideradas. Além disso, o valor da densidade, $\sim 5,17 \mathrm{~g} / \mathrm{cm}^{3}$ para a ferrita sintetizada, é intermediário aos valores esperados para os materiais maciços [53] - ferritas de cobalto $\left(5,29 \mathrm{~g} / \mathrm{cm}^{3}\right)$ e de manganês $\left(4,87 \mathrm{~g} / \mathrm{cm}^{3}\right)$ - indicando o caráter misto da composição das NPs. Entretanto, é necessário considerar que, devido à dimensão reduzida (i.e. maior relação superfície/volume) e à presença de óxidos/hidróxidos de ferro de menor densidade na superfície das nanopartículas, uma variação do valor dessa densidade pode ser esperado.

Finalmente, com o intuito de verificar a composição química das nanopartículas, foi feita a dosagem das mesmas por espectroscopia de emissão atômica com plasma indutivamente acoplado (ICP-OES). As proporções molares Fe:(Co+Mn) e Co:Mn 
encontradas após a síntese do precipitado foram muito próximas a 2:1 e 1:1, conforme esperado, pela estequiometria dos reagentes utilizados na síntese.

\section{3 Funcionalização das nanopartículas e peptização em meio não aquoso}

Conforme descrito na seção 4.1, no fluido magnético preparado, a repulsão necessária para peptização das nanopartículas é originada, eletrostaticamente, das cargas elétricas originadas na superfície dos nanomateriais. Pela limitação dos equilíbrios químicos, esse modelo contempla, somente, estabilidade aos fluidos em meios aquosos com pHs mais ácidos ou mais básicos. Em meio neutro, a baixa densidade de cargas elétricas impede a peptização das nanopartículas e estabilização do colóide. Para algumas aplicações, entretanto, há necessidade de fluidos magnéticos em pHs neutros, como é o caso da maioria das biológicas. Para elaborar esse tipo de material, uma das estratégias mais utilizadas é a funcionalização da superfície das nanopartículas com moléculas polifuncionais, polieletrólitos, polímeros, etc. De uma maneira geral, essas espécies induzem certo caráter estérico de repulsão interparticular, mas, principalmente, os grupos funcionais de superfície instalados alteram as condições de ionização (i.e, e o

surgimento de cargas), mesmo em pHs neutros. Um exemplo clássico é a funcionalização com ácido cítrico [54], um ácido triprótico com valores de $\mathrm{p} K_{\mathrm{a}}$ iguais a 3,1, 4,8 e 6,4. Nessa funcionalização, dois grupamentos carboxilato coordenam-se à superfície da partícula, enquanto o terceiro se ioniza, no seio da solução, gerando uma densidade de cargas superficiais, o que permite a obtenção de coloides estáveis em meios neutro a levemente alcalinos. Outra alternativa para peptização é adsorção de surfactantes à superfície das nanopartículas, que induz repulsão estérica entre as 
mesmas - a parte polar dessas moléculas interagem com as nanoestruturas enquanto a seção hidrofóbica interage com o solvente. Pelo caráter apolar, salvo no caso de uma dupla surfactação, esse modelo fica limitado a solventes orgânicos que apresentem afinidade por essas moléculas. É nesse sentido que se propõe, nesse trabalho, a funcionalização das nanopartículas com moléculas não ionizáveis, mas com cadeias polares, capazes de interagir com solventes não aquosos e não contemplados pelo modelo de surfactantes. Particularmente, as cadeias contendo grupamentos hidroxila $(-\mathrm{OH})$ foram escolhidas, uma vez que mimetizam vários solventes como álcoois e poliois, em que a peptização de nanopartículas não é facilmente contemplada pelos modelos descritos anteriormente. De maneira específica, as moléculas de ácido glicérico e de ácido glucônico foram selecionadas. Conforme mostrado na tabela 2, tratam-se de ácidos monopróticos com a cadeia carbônica polihidroxilada.

2,3-dihidroxopropanóico


Dessa maneira, o grupamento carboxilato coordena-se à superfície da nanopartículas e a cadeia hidroxilada interage com o solvente. Mais precisamente, a afinidade do sistema funcionalizado será maior por solventes mais polares e, especialmente, por aqueles que possam interagir via ligação de hidrogênio com as NP funcionalizadas. Para otimizar a ligação das moléculas escolhidas à superfície das NP, é necessário levar em conta as propriedades químicas desses dois sistemas: por um lado, a superfície das NP é rica em metais de transição (especialmente o ferro), mas que estão coordenados com espécies provenientes de um equilíbrio com o meio aquoso, conforme discutido na seção 3.1. Por outro lado, as moléculas desses ácidos hidroxilados apresentam um grupo funcional ácido carboxílico que, na sua forma desprotonada, complexa facilmente aos metais da superfície das NP. No entanto, o status desses dois sistemas é fortemente alterado conforme o $\mathrm{pH}$ do meio. De fato, esses ácidos carboxílicos sofrem dissociação ácida em meio aquoso, segundo o equilíbrio descrito na equação 4, cujos valores de $\mathrm{p} K_{\mathrm{a}}$ estão listados na tabela 2 ( $\mathrm{R}$ é a cadeia carbônica hidroxilada).

$$
\mathrm{R}-\mathrm{COOH}+\mathrm{H}_{2} \mathrm{O} \text { É } \quad \mathrm{R}-\mathrm{COO}^{-}+\mathrm{H}_{3} \mathrm{O}^{+}
$$

A figura 21 ilustra a situação ideal para a complexação dos metais superficiais pela molécula do ácido em questão. A forma desprotonada do ácido (R-COO), negativamente carregada, tem grande afinidade pelas NP positivamente carregadas $\left(\mathbf{D}-\mathrm{OH}_{2}{ }^{+}\right)$. Conforme representado na figura 21, o grupo carboxilato, que é um doador de elétrons, substitui o grupo $-\mathrm{OH}_{2}^{+}$ligado ao sítio superficial, estabelecendo um complexo estável com a partícula. 


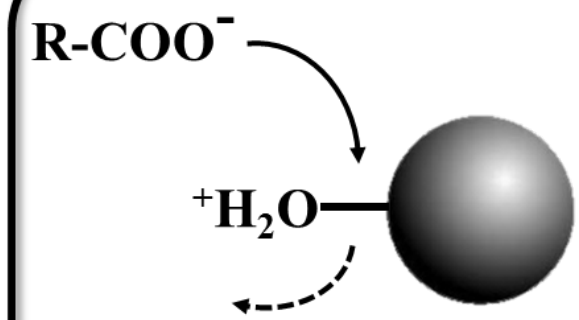

Figura 21 - Representação da complexação da superfície das NPMs pelos ligantes ácido glicérico e ácido glucônico (R-COOH) via carboxilato.

Assim, levando-se em conta a superfície da NP e o ligante, para um maior rendimento na funcionalização, deve ser ponderada a dependência que as espécies têm em relação ao $\mathrm{pH}$ do meio. Isso é melhor entendido a partir dos diagramas de especiação mostrados na figura 22.

Nesse diagrama, os percentuais de cada espécie estão traçados em função do pH. As curvas pontilhada, tracejada e tracejada-pontilhada em vermelho representam, respectivamente, as frações das espécies $\mathbf{D}-\mathrm{OH}_{2}^{+}, \mathbf{D}-\mathrm{O}^{-}$e D-OH das NP. A curva em azul representa a variação da espécie R-COO` do ácido carboxílico. Em pHs que vão de neutros a alcalinos, apesar de os ligantes ácidos estarem desprotonados e aptos a se complexar, as nanopartículas estão descarregadas ou apresentam cargas negativas em sua superfície, o que diminui a eficiência de ligação dessas moléculas com o sólido. A interação será mais efetiva, conforme mostrado na figura 21, em pH ácido. De acordo com as curvas de especiação mostradas na figura w2, existe um $\mathrm{pH}$ ótimo, em que as NP estão maximamente na forma $-\mathrm{OH}_{2}{ }^{+}$e o ligante na forma $\mathrm{R}-\mathrm{COO}$. Esse $\mathrm{pH}$ é igual $\mathrm{a}\left(\mathrm{p} K_{\mathrm{L}}+\mathrm{p} K_{1}\right) / 2$, em que $\mathrm{p} K_{\mathrm{L}}$ é o $\mathrm{p} K_{\mathrm{a}}$ do ligante $\mathrm{e} \mathrm{p} K_{1}$ é relativo à primeira dissociação descrita pela equação (2). 


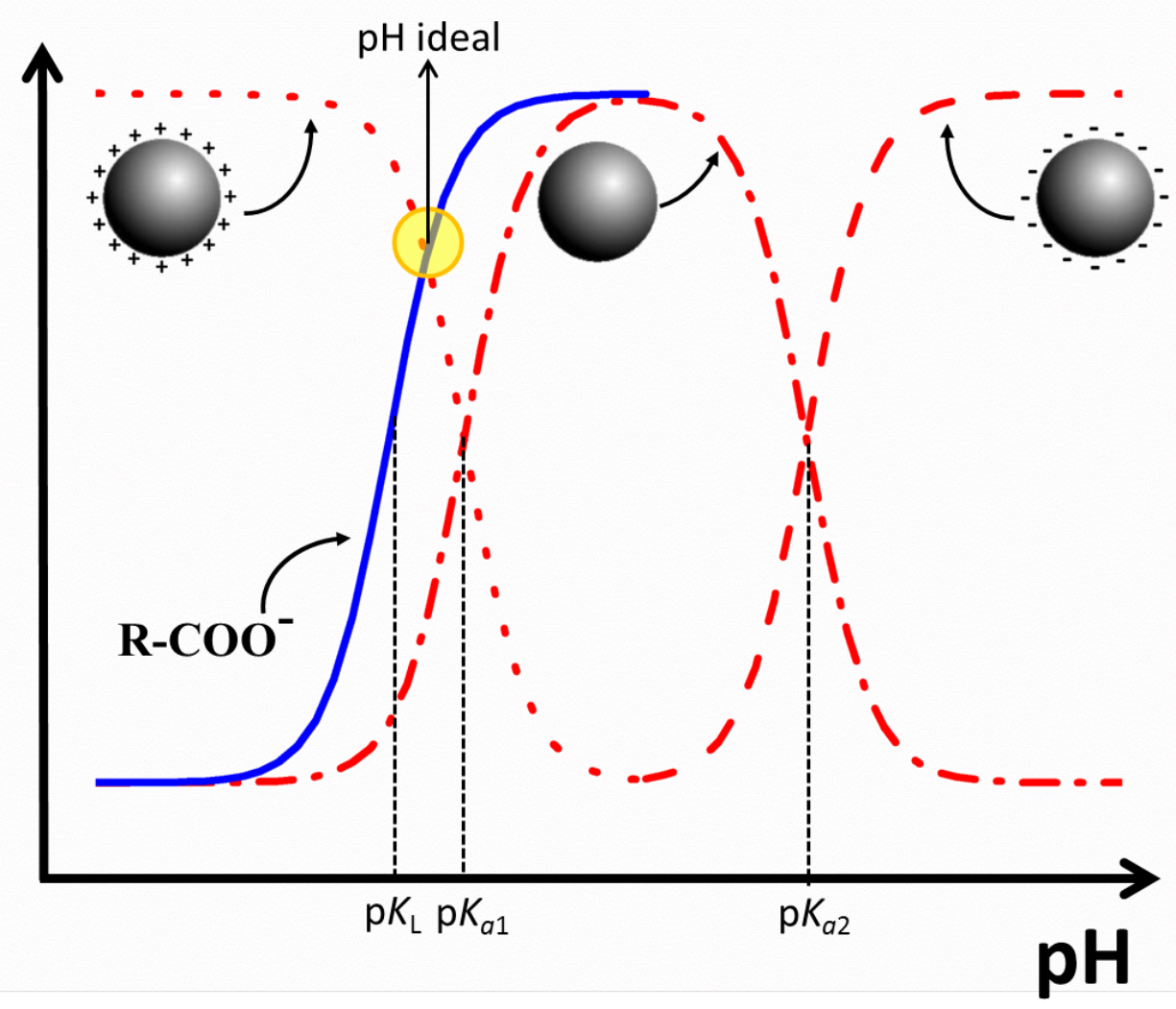

Figura 22 - Diagramas de especiação da superfície das NPMs (em vermelho) e dos ligantes (em azul). As constantes de dissociação ácidas das $\mathrm{NPs}\left(\mathrm{p} K_{\mathrm{a} 1}\right.$ e $\left.\mathrm{pK}_{\mathrm{a} 2}\right)$ e do ligante $\left(\mathrm{p} K_{\mathrm{L}}\right)$, assim como o $\mathrm{pH}$ ideal de complexação, estão indicados na figura.

A partir desse raciocínio, considerando-se que para esse tipo de ferrita o $\mathrm{p} K_{1}$ médio gira em tordo de 5 e levando-se em conta os valores de $\mathrm{p} K_{\mathrm{L}}$ listados na tabela 2 , determinou-se um pH ótimo para acoplamento: 4,4 para ácido glicérico e 4,8 para o ácido glucônico. Além disso, a razão de $2 \mathrm{mmol}$ de ligante por mg de NP foi utilizada, uma vez que é capaz saturar a superfície das nanoestruturas. Após serem funcionalizadas, as NP foram lavadas com acetona a fim de se retirar o excesso de ligantes não acoplados ao sólido. Para se verificar a efetividade da funcionalização, análises por espectroscopia de absorção no infravermelho e por espalhamento dinâmico de luz (DLS) foram realizadas. 
A figura 23 mostra os espectros FTIR obtidos para as nanopartículas não funcionalizadas (NFNP) não funcionalizadas e funcionalizadas com ácido glicérico (GYANP) e com ácido glucônico (GUANP). As bandas verificadas em torno de 630, 580 e $450 \mathrm{~cm}^{-1}$, que são comumente atribuídas às vibrações $\mathrm{Fe}-\mathrm{O}$ da estrutura do óxido podem ser vistas, na ampliação do espectro para nanopartículas recobertas com ácido glucônico [55,56]. Além disso, na amostra sem a cobertura de ácidos, as bandas localizadas em torno de $3430 \mathrm{~cm}^{-1}, 1620 \mathrm{~cm}^{-1}$ e $1340 \mathrm{~cm}^{-1}$ são respectivamente devidas ao estiramento $v(\mathrm{OH})$ e dobramentos $\mathrm{HOH}(\delta(\mathrm{HOH}))$ e $\mathrm{H}-\mathrm{O} \cdots \mathrm{H}(\delta(\mathrm{H}-\mathrm{O} \cdots \mathrm{H}))$ da água adsorvida na superfície do óxido. [57,58,59]. A banda que aparece em torno de $1085 \mathrm{~cm}^{-1}$ é atribuída ao estiramento $v(\mathrm{CO})$ dos grupos $\mathrm{C}-\mathrm{OH}$ dos ácidos glicérico e glucônico. A presença dessa banda nas amostras funcionalizadas e ausente na amostra NFNP é um forte indício do acoplamento dos ligantes às NP. Nas amostras GYANP e GUANP, as bandas localizadas em torno de $3430 \mathrm{~cm}^{-1}$ são atribuídas ao estiramento $v(\mathrm{OH})$ provenientes não só da água adsorvida, mas também dos grupamentos $-\mathrm{OH}$ dos ácidos. A banda situada na região de $1620 \mathrm{~cm}^{-1}$ é atribuída ao estiramento assimétrico dos grupamentos carboxílicos $\left(v\left(\mathrm{CO}_{2}^{-}\right)\right)$acoplado aos dobramentos $\mathrm{HOH}(\delta(\mathrm{HOH}))$ da água adsorvida. Bandas, na região de $1400-1450 \mathrm{~cm}^{-1}$, relativas ao estiramento simétrico dos grupamentos carboxílicos $\left(v\left(\mathrm{CO}_{2}^{-}\right)\right)$não foram observados no espectro. Todas essas observações indicam que houve complexação da superfície das NP pelos ligantes e que as cadeias hidroxiladas estão disponíveis para interagir com o solvente. 


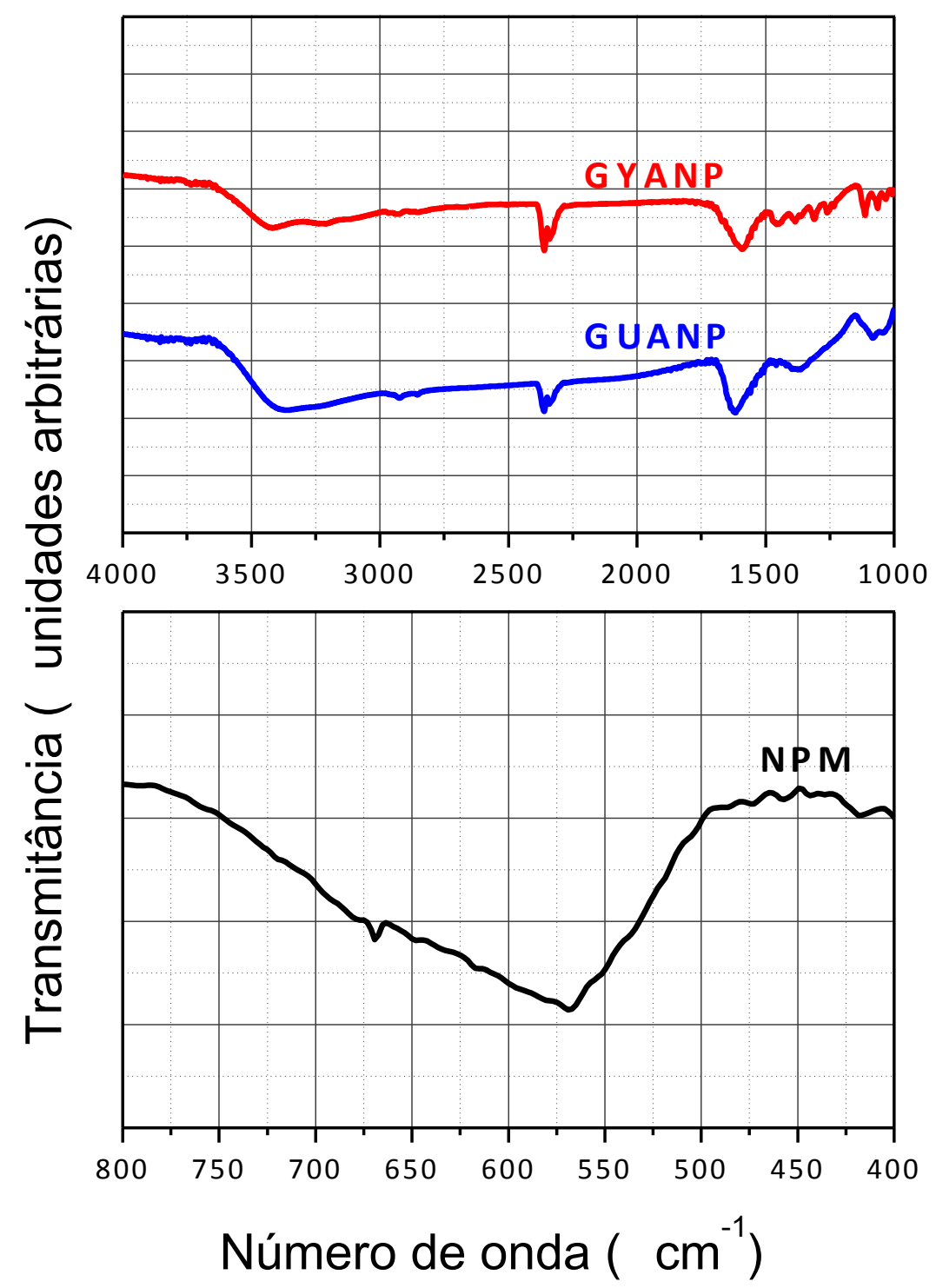

Figura 23 - Espectros de FTIR para as amostras de NPs funcionalizadas com ácido glicérico (GYANP) e ácido glucônico (GUANP), evidenciando a interação dos ligantes com a NP (acima) e (abaixo) contribuição da ferrita (NPM), para o espectro.

Conforme discutido na introdução, diferentes modos de complexação do ácido glucônico à superfície das NPMs são possíveis, via carboxilato e grupos $\alpha$-hidroxílicos. Além disso, a complexação na forma lactônica também é possível. Muito provavelmente, e como indicam os resultados de FTIR, os ácidos glucônico e glicérico 
estão coordenados via carboxilato, mantendo a cadeia polihidroxílica voltada para solução. Apesar de não serem totalmente conclusivas, essas informações sobre o modelo de interação, por FTIR, outros resultados que corroboraram para o sucesso da funcionalização foram obtidos por espalhamento de luz dinâmico. Ao se comparar as características das amostras funcionalizadas com aquela sem funcionalização, conforme esperado e ilustrado na figura $22, \mathrm{em} \mathrm{pH}=4$, a amostra não funcionalizada apresentou carga positiva enquanto as amostras GYANP e GUANP (funcionalizadas) apresentaram carga praticamente nula. Isso é melhor visualizado no gráfico da figura 24 , que mostra o potencial zeta medido em função do $\mathrm{pH}$.

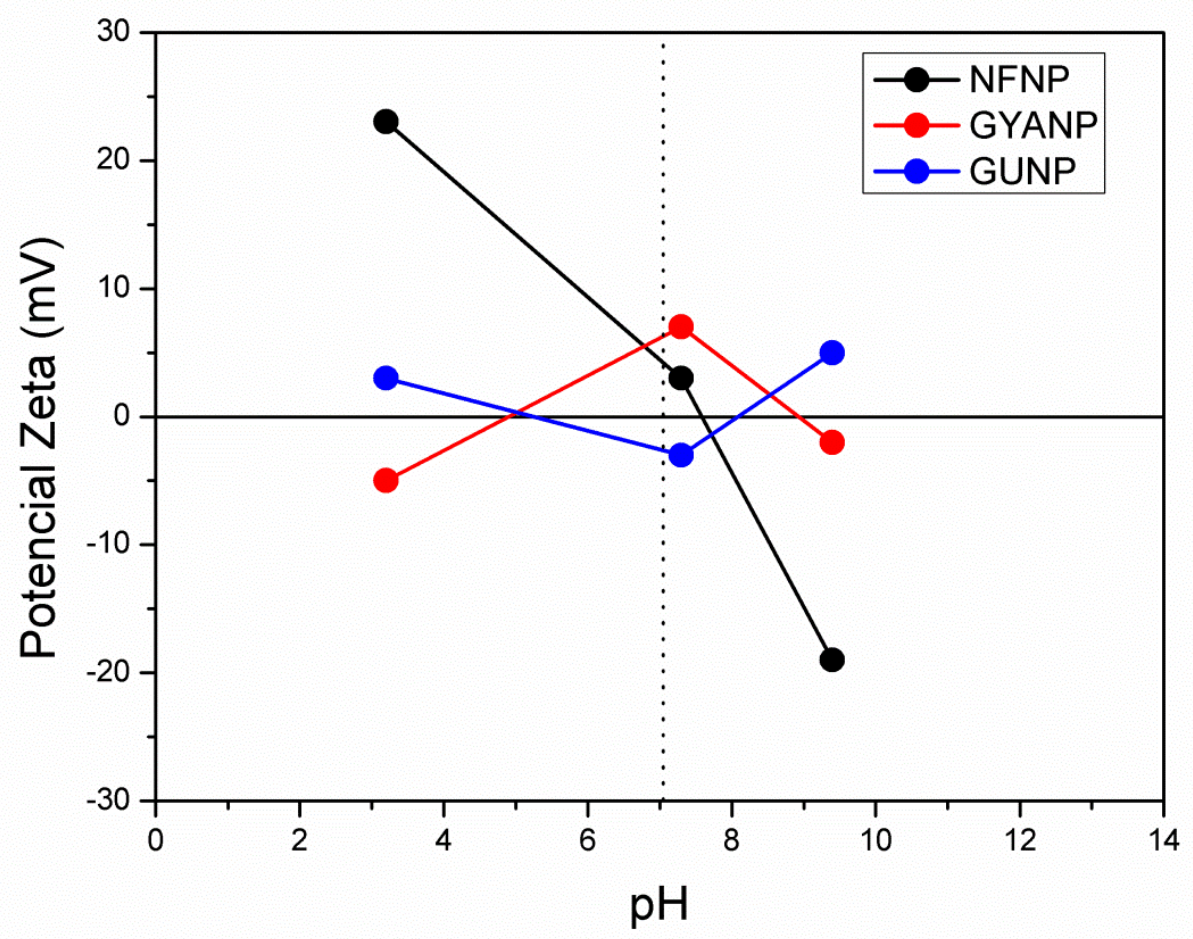

Figura 24 - Variação do potencial zeta, em função do pH, para NPs funcionalizadas com ácido glicérico (GYANP) e ácido glucônico (GUANP) e sem funcionalização (NFNP). 
Além disso, a densidade de carga superficial das NPs não funcionalizadas passa por zero e se torna negativa à medida que o $\mathrm{pH}$ varia, enquanto que, para as NPs recobertas com os ácidos, essa carga não varia. Isso é um forte indício que os ligantes, desprovidos de cargas, quando adsorvidos, reconfiguram a superfície das NPs.

Após lavagem do excesso de ligantes não acoplados, as NPs funcionalizadas foram dispersas em glicerol (propano-1,2,3-triol). Em seguida, o excesso de acetona usado nas lavagens foi extraído em um evaporador rotativo e pôde-se se obter um sol estável. Nesse modelo, conforme ilustrado na figura 25, a superfície das nanopartículas funcionalizadas mimetiza o solvente, que é um poliálcool, $\mathrm{CH}_{2}(\mathrm{OH})-\mathrm{CH}(\mathrm{OH})$ $\mathrm{CH}_{2}(\mathrm{OH})$. A interação entre as NPs e o solvente é de caráter forte, já que ligações de hidrogênio podem se estabelecer entre eles.

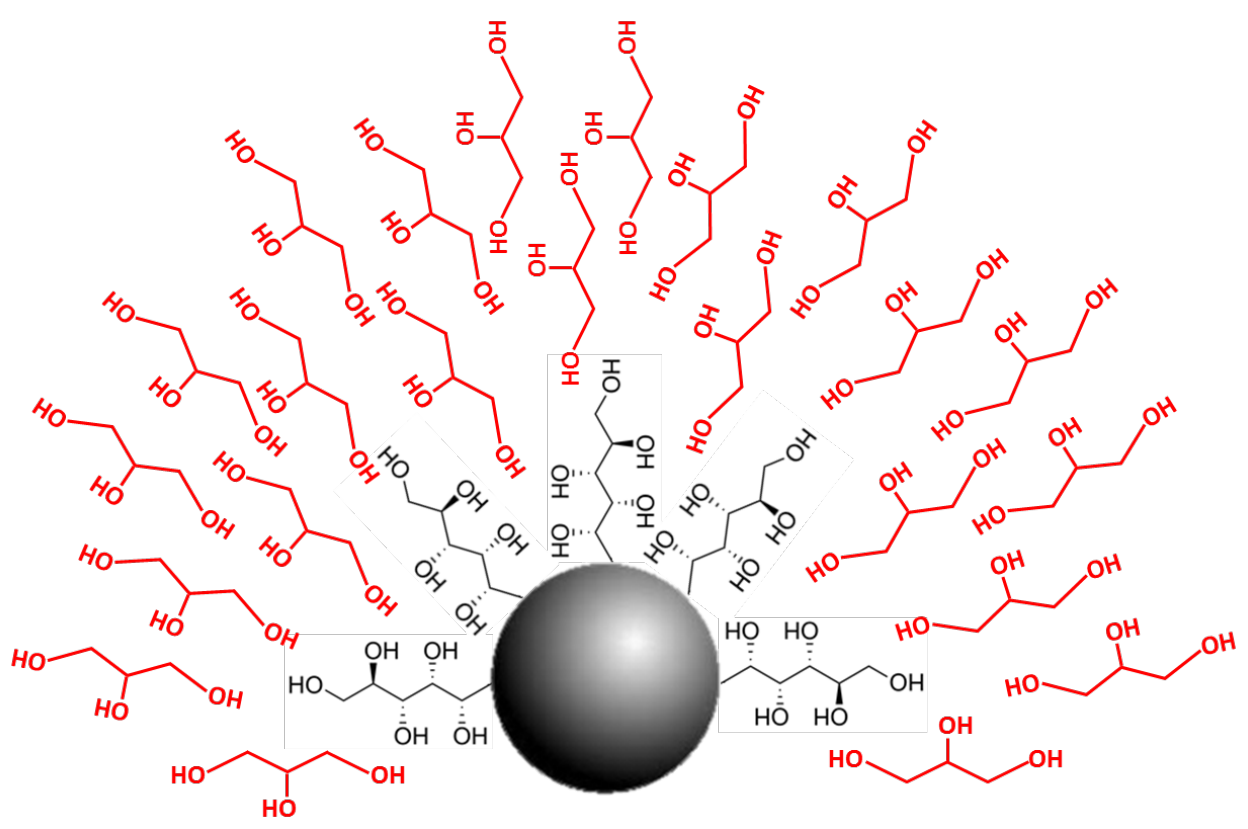

Figura 25 - Modelo de interação entre a superfície modificada das NPMs e o glicerol. 
Testes qualitativos também foram feitos para verificar a compatibilidade das NPs funcionalizadas em diversos álcoois e em água. Para tal, $50 \mu \mathrm{L}$ das amostras funcionalizadas (concentração aproximada de 5\% em massa) foram diluídos em $10 \mathrm{~mL}$ de água, glicerol, isoprapanol, butanol e etanol. Em seguida, as suspensões foram homogeneizadas em um agitador vortex, por 10 minutos, e submetidas a um campo magnético estático (colocadas sobre um ímã permanente por 30 minutos). Para um controle, NPs não funcionalizadas foram dispersas em álcool etílico, nas mesmas condições das NPs funcionalizadas. A foto da figura 26 mostra o aspecto das amostras após o experimento. É possível notar que, enquanto as NPs funcionalizadas apresentam estabilidade coloidal nos álcoois com diferentes tamanhos de cadeia e números de hidroxila (caso do glicerol), além da água, a amostra contendo NPs não funcionalizadas em álcool etílico coagula. Isso é um indício do sucesso da funcionalização nos termos discutidos anteriormente, pelas técnicas de FTIR e potencial zeta.

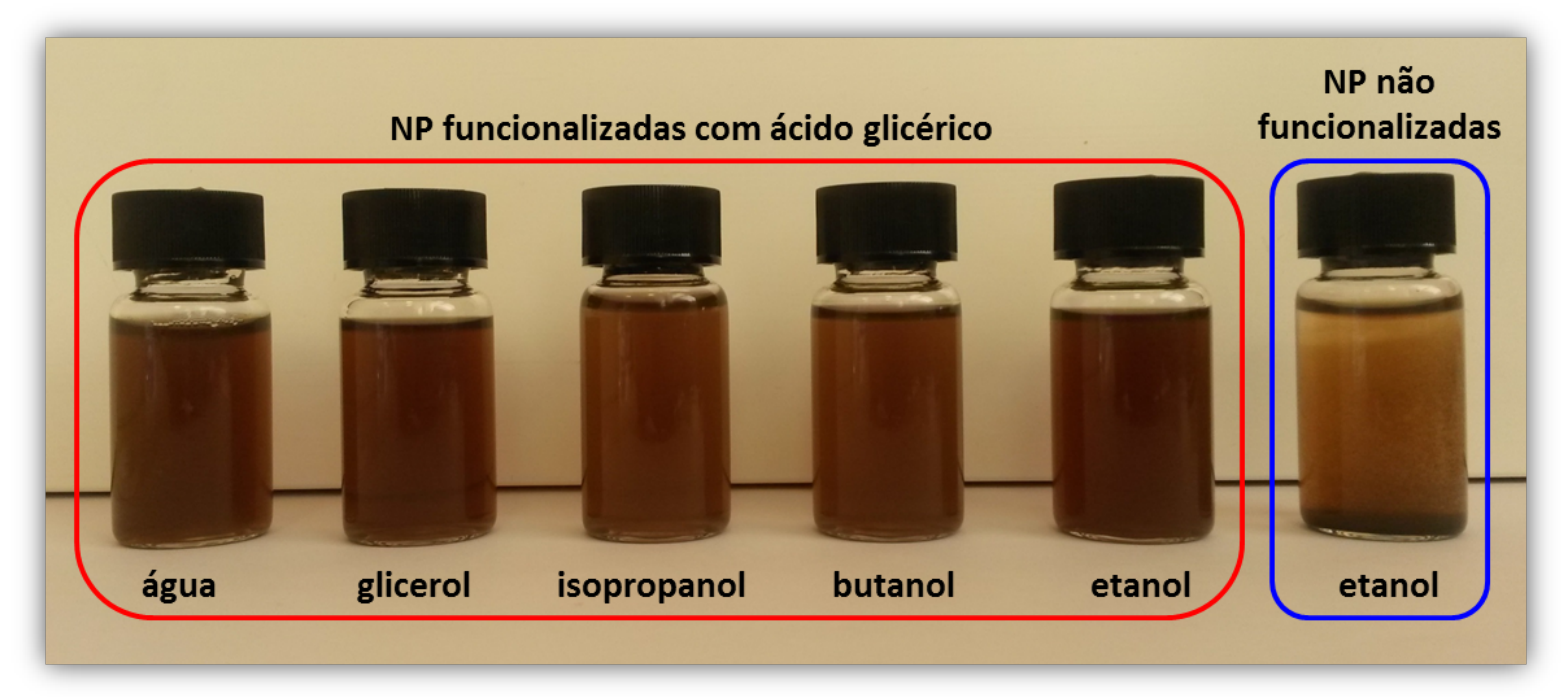

Figura 26 - Aspecto das dispersões de NPs funcionalizadas com ácido glucônico em diversos solvente, após serem submetidas a um campo magnético estático. 


\subsection{Medida de concentração do coloide pela densidade do fluido}

O valor da concentração de um coloide é um fator importante e indispensável para compreensão de suas propriedades físicas e físico-químicas. No caso dos sóis, como os fluidos magnéticos aqui estudados, essa concentração pode ser expressa pelo número de partículas dispersas ou pela sua fração volumétrica em relação a determinado volume do sol ou, mais comumente, pela fração em massa dessas nanopartículas em relação à massa do coloide $(\phi)$. Nesse caso, diferentemente das soluções de solutos discretos, tem-se que a densidade do fluido magnético $\left(d_{\mathrm{FF}}\right)$ é linearmente e aproximadamente proporcional à sua concentração, conforme ilustrado no gráfico da Figura 27, abaixo.

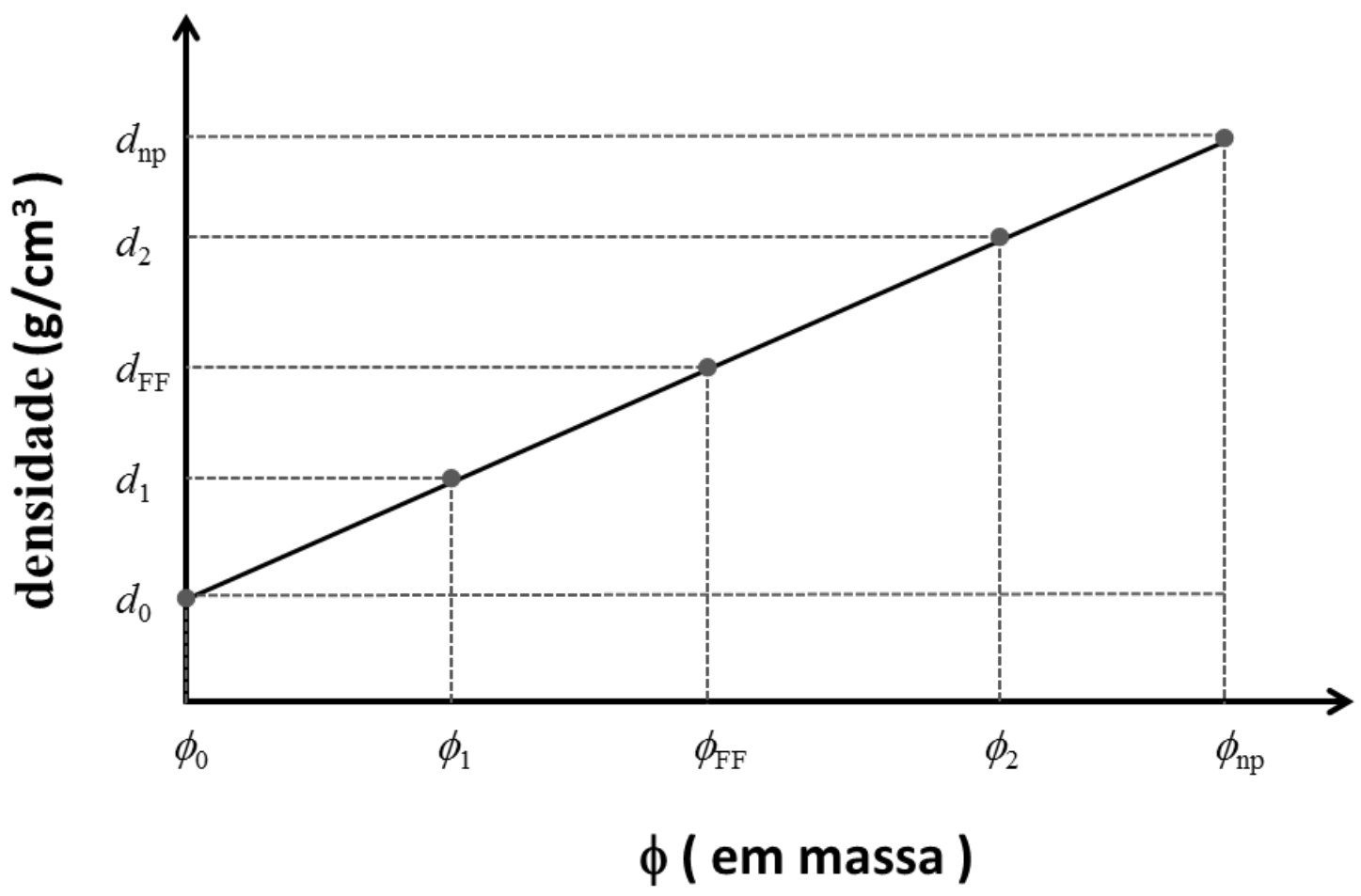

Figura 27 - Variação da densidade em função da concentração em massa de um sol. 
Pelo gráfico, é possível estabelecer a relação $\frac{d_{\mathrm{np}}-d_{0}}{\phi_{\mathrm{np}}-\phi_{0}}=\frac{d_{\mathrm{FF}}-d_{0}}{\phi_{\mathrm{FF}}-\phi_{0}}$, em que um fluido magnético de concentração $\phi_{\mathrm{FF}}$ e densidade $d_{\mathrm{FF}}$, é composto por nanopartículas de densidade $d_{\text {np }}$ dispersas em um solvente de densidade $d_{0}$. Na ausência de soluto, $\phi_{\mathrm{FF}}=\phi_{0}=0$ e, para o soluto sólido, o valor de concentração é $\phi_{\mathrm{np}}=1$. Dessa forma, a equação pode ser reescrita na forma: $d_{\mathrm{FF}}=\phi_{\mathrm{FF}} d_{\mathrm{np}}+d_{0}\left(1-\phi_{\mathrm{FF}}\right)$.

O gráfico da Figura 28 mostra como varia a densidade, medida experimentalmente, para um fluido magnético diluído, sucessivamente, por crescentes fatores de diluição (FD). Note que a concentração de uma amostra diluída $\left(\phi_{\text {dil }}\right)$ é igual a $\phi_{\mathrm{dil}}=1 / \mathrm{FD} \times \phi_{\mathrm{FF}}$.

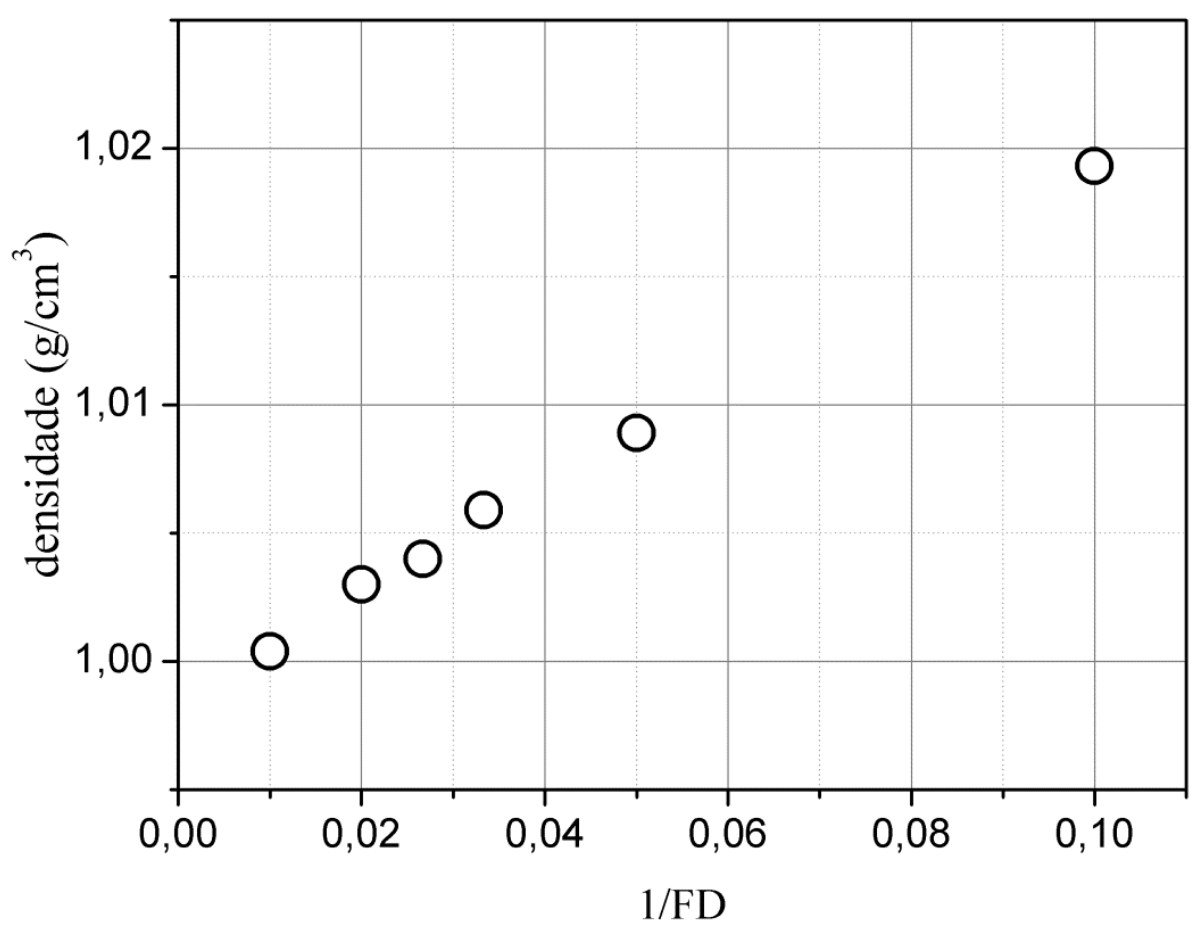

Figura 28 - Variação da densidade para o fluido magético constituído de NPs não funcionalizadas, obtido no procedimento descrito na seção 3.1 . 
Na Figura 27, para duas diluições quaisquer, de concentrações $\phi_{1}$ e $\phi_{2}$ (em que $\phi_{1}$ $\left.<\phi_{2}\right)$ e densidades, respectivamente, $d_{1}$ e $d_{2}\left(d_{1}<d_{2}\right), \frac{d_{\mathrm{np}}-d_{2}}{\phi_{\mathrm{np}}-\phi_{2}}=\frac{d_{2}-d_{1}}{\phi_{2}-\phi_{1}}$ e, levando-se em conta que $\phi_{2}=1 / \mathrm{FD} \times \phi_{1}$, pode-se estabelecer a relação mostrada na equação 5:

$$
\phi_{2}=\left(\frac{1}{\frac{d_{\mathrm{np}}-d_{2}}{d_{2}-d_{1}}(1-\mathrm{FD})+1}\right) \times 100 \%
$$

\begin{tabular}{|c|c|c|c|c|c|}
\hline Am5ostra & 1/FD & FD & $\begin{array}{c}\text { Densidade } \\
\left(\mathrm{g} / \mathrm{cm}^{3}\right)\end{array}$ & $\begin{array}{l}\text { Concentração } \\
\text { (\% em massa) }\end{array}$ & $\begin{array}{c}\text { Temperatura } \\
\left({ }^{\circ} \mathrm{C}\right)\end{array}$ \\
\hline \multirow{6}{*}{ NFNP } & 0,100 & 10,0 & 1,0193 & 0,503 & 20,05 \\
\hline & 0,050 & 20,0 & 1,0089 & 0,252 & 20,06 \\
\hline & 0,033 & 30,0 & 1,0059 & 0,168 & 20,08 \\
\hline & 0,027 & 37,5 & 1,0040 & 0,134 & 20,04 \\
\hline & 0,020 & 50,0 & 1,0030 & 0,101 & 20,02 \\
\hline & 0,010 & 100,0 & 1,0004 & 0,050 & 20,02 \\
\hline \multirow{3}{*}{ GYANP } & 0,394 & 2,5 & 1,3071 & 1,431 & 20,01 \\
\hline & 0,165 & 6,1 & 1,2740 & 0,598 & 20,09 \\
\hline & 0,024 & 41,6 & 1,2544 & 0,087 & 20,01 \\
\hline \multirow{3}{*}{ GUANP } & 0,308 & 3,2 & 1,2833 & 0,727 & 20,02 \\
\hline & 0,108 & 9,3 & 1,2644 & 0,254 & 20,02 \\
\hline & 0,060 & 16,7 & 1,2604 & 0,141 & 20,02 \\
\hline
\end{tabular}

Tabela 3 - Dados de diluição de e densidade para as amostras analisadas. 
A equação 5 permite determinar a concentração (fração percentual em massa) para um sol, apenas a partir da medida da densidade de duas alíquotas de concentrações distintas e cujo fator de diluição é conhecido, entre as mesmas. Nesse caso, é necessário, também, se conhecer a densidade do sólido que compõe esse sol. Dessa forma, a partir dos dados mostrados na Tabela 3 e plotados no gráfico da Figura 28, foi possível traçar uma curva de densidade versus concentração, conforme mostra a Figura 29. O valor da densidade para o sólido foi extraído do refinamento dos dados de raios $\mathrm{X}, d_{\mathrm{np}}=5,17$ $\mathrm{g} / \mathrm{cm}^{3}$.

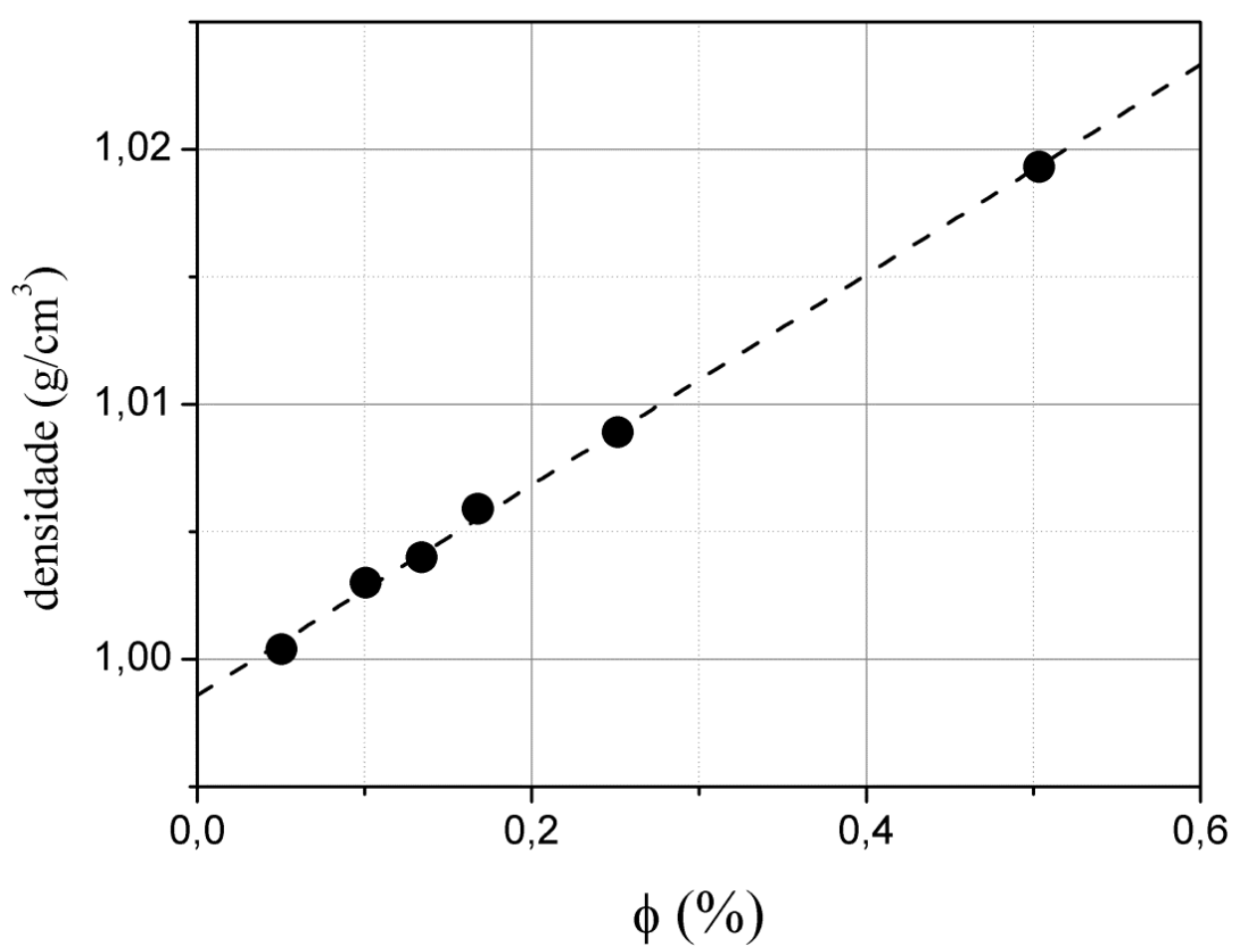

Figura 29 - Gráfico da densidade em função da fração em massa para a amostra não funcionalizada, calculada de acordo com o modelo proposto no texto.

A partir da equação de reta obtida no ajuste dos dados da curva desse gráfico, o valor de interceptação equivale à densidade do solvente, nesse caso água. $\mathrm{O}$ valor encontrado foi de $d_{0}=0,9986 \mathrm{~g} / \mathrm{cm}^{3}$, idêntico ao medido experimentalmente para água 
pura, nas mesmas condições. Além disso, utilizando-se a equação de ajuste, para $\phi_{\mathrm{FF}}=$ $100 \%$, a densidade do sólido estimada foi de $5,16 \mathrm{~g} / \mathrm{cm}^{3}$, próximo ao valor determinado experimentalmente dor DRX.

Da mesma forma, um gráfico de densidade versus fração percentual em massa foi plotado com os dados para as amostras funcionalizadas com ácido glicérico e com ácido glucônico e dispersas em glicerol, um solvente com características distintas da água (Figura 30).

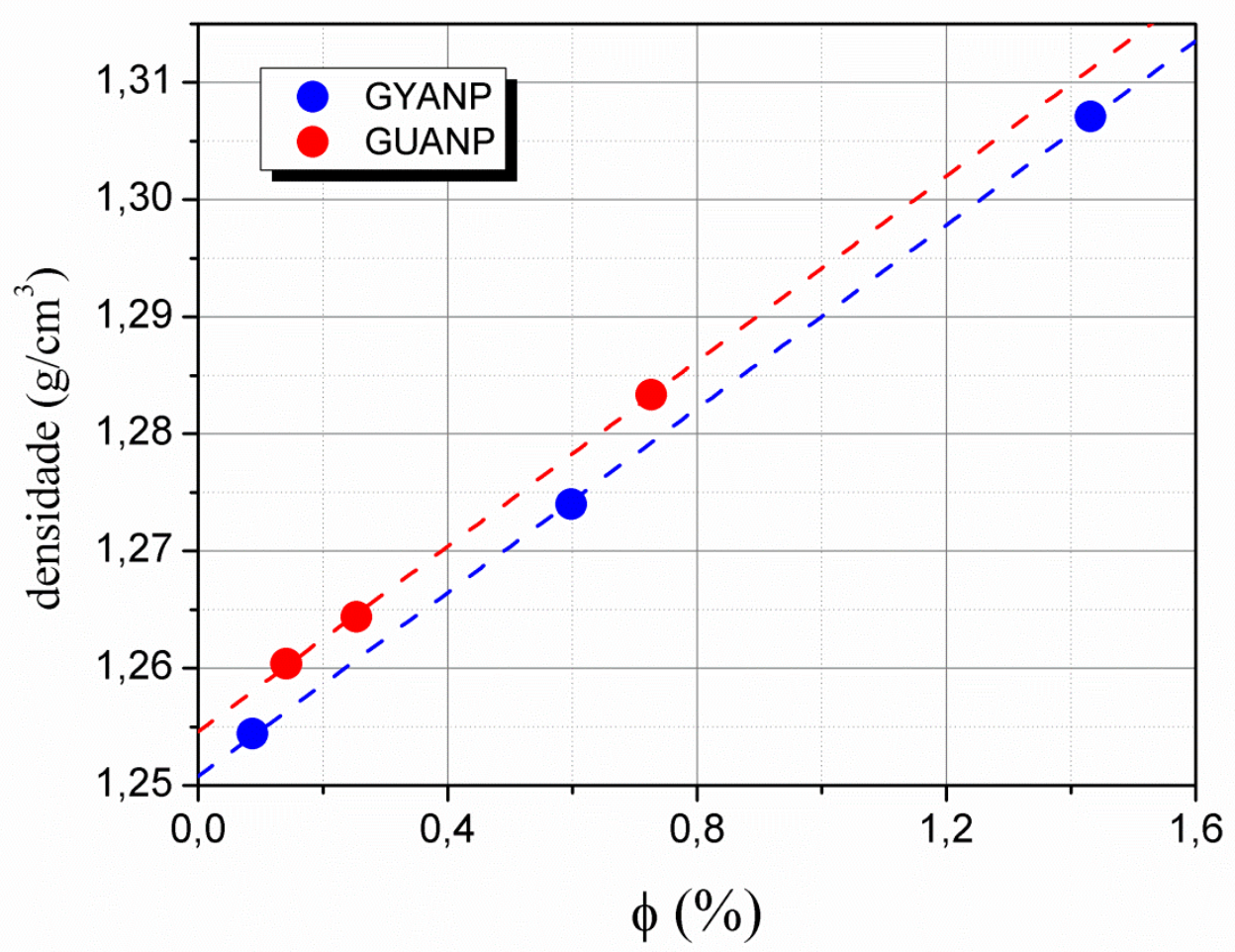

Figura 30 - Gráfico da densidade em função da fração em massa para as amostras funcionalizadas com ácido glicérico e glucônico.

Conforme observado para a amostra em que as nanopartículas estavam dispersas em meio aquoso, para as amostras funcionalizadas e dispersas em glicerol, um comportamento similar foi verificado. O ajuste linear também mostrou grande 
correlação dos dados e a partir dos dados extraídos das curvas, foi possível comprovar a validade do método de determinação de concentração, por meio de medidas de densidade. Nesses dois casos, as densidades do solvente extrapoladas da interceptação da reta foram bastante coerentes com o valor determinado experimentalmente e as densidades para o sólido também foram próximas do valor determinado por XRD. A não sobreposição das curvas obtidas para nanopartículas funcionalizadas com os dois diferentes ligantes pode ter sido originada pelo fato que os ligantes são distintos em tamanho e massa e, por de estarem acoplados à superfície das nanopartículas, uma alteração do sistema pode ter ocorrido, modificando a densidade das mesmas. De fato, as densidades estimadas $-5,19 \mathrm{~g} / \mathrm{cm}^{3}$ e $5,20 \mathrm{~g} / \mathrm{cm}^{3}$, respectivamente para nanopartículas funcionalizadas com ácido glicérico e com ácido glucônico - estão um pouco acima daquela encontrada para o sistema aquoso $\left(5,16 \mathrm{~g} / \mathrm{cm}^{3}\right)$.

A proposição desse método é bastante importante já que a determinação da concentração de coloides é bastante laboriosa, e imprecisa em alguns casos, envolvendo técnicas indiretas de dosagens caras e pouco acessíveis. Nesse caso, a utilização de um densímetro (equipamento de baixo custo) já é suficiente para determinar, com boa precisão, as densidades das diversas alíquotas e, assim estimar a concentração do sol. As limitações desse método estão, principalmente, na dependência do valor da densidade do sólido que compõe o coloide, o que nem sempre pode ser deduzido, pela grande variação composicional dos materiais, oriundos de diversos tipos de sínteses. Entretanto, isso pode ser contornado pela determinação experimental da densidade das partículas por técnicas indiretas (como DRX) ou diretas, como é o caso da picnometria com hélio. 


\subsection{Caracterização magnética}

A figura 31 mostra a curva de magnetização $(M)$, à temperatura ambiente, em função do campo magnético aplicado $(H)$, para as nanopartículas sintetizadas, na forma de pó, conforme descrito anteriormente.

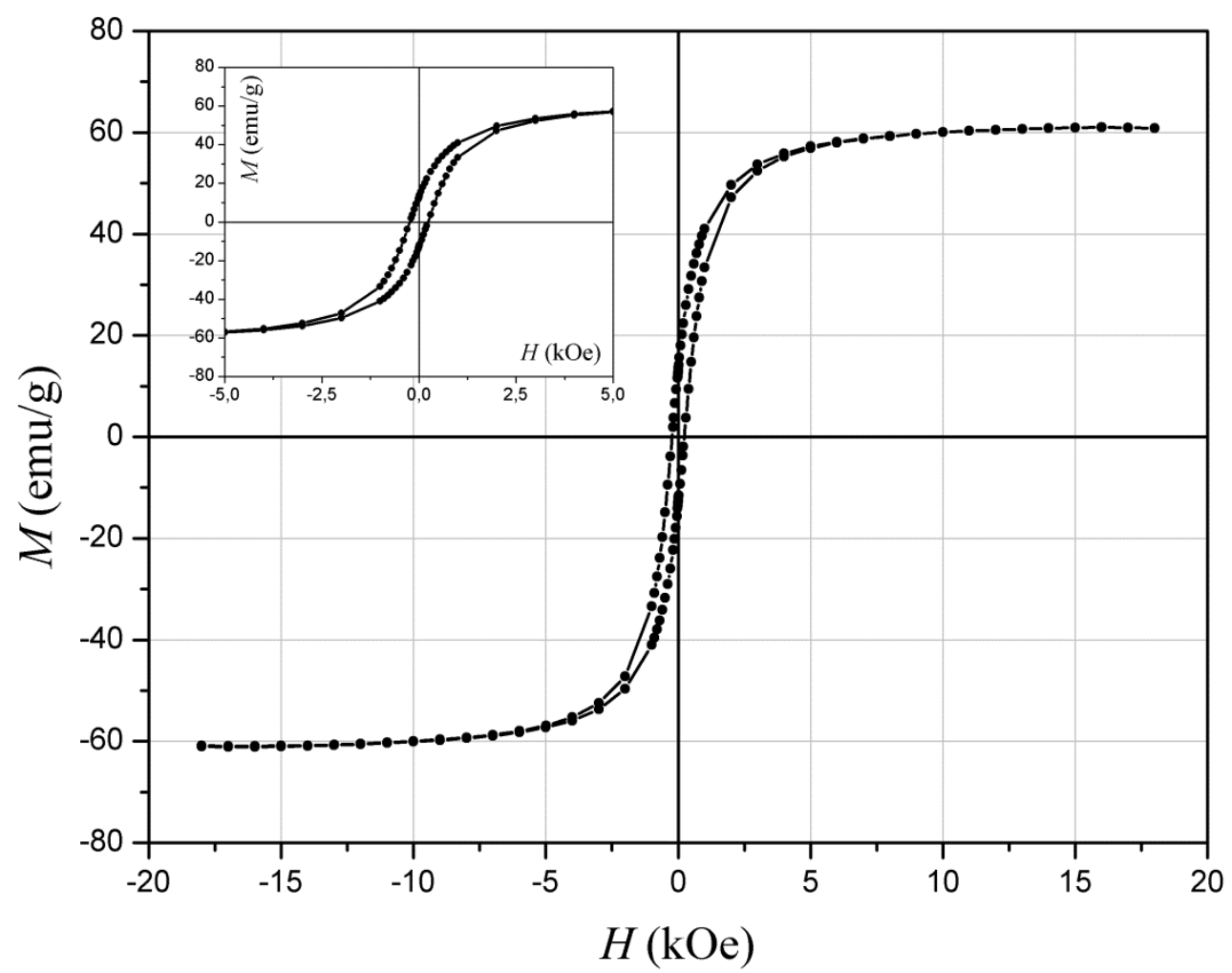

Figura 31 - Curva de magnetização versus campo magnético aplicado para as NPs não funcionalizadas. O gráfico em detalhe mostra a histerese.

A curva indica que a magnetização aumenta à medida que o campo magnético se intensifica, até atingir magnetização de saturação igual a $61 \mathrm{emu} / \mathrm{g}$, valor maior que para nanopartículas de tamanho similar de magnetita, maguemita, ferrita de cobalto ou ferrita de manganês obtidas pelo mesmo tipo de síntese [60]. Entretanto, a análise das 
características magnéticas desse materiais exige estudos mais aprofundados, já que nessa dimensão, há redistribuição catiônica [61] e efeitos de superfície e de tamanho finito característicos da nanoescala [62,63]. Quando o campo é diminuído e invertido para fechar o ciclo de histerese, é possível notar que há magnetização remanente e campo coercitivo iguais, respectivamente, iguais a $12 \mathrm{emu} / \mathrm{g}$ e $230 \mathrm{Oe}$, indicando que as partículas apresentam características ferromagnéticas.

As magnetizações das amostras de fluidos magnéticos, aleatoriamente diluídos, preparados em meio aquoso e a partir da funcionalização das NP com ácido glicérico e ácido glucônico e dispersas em glicerol também foram medidas e são mostradas na figura 32 .

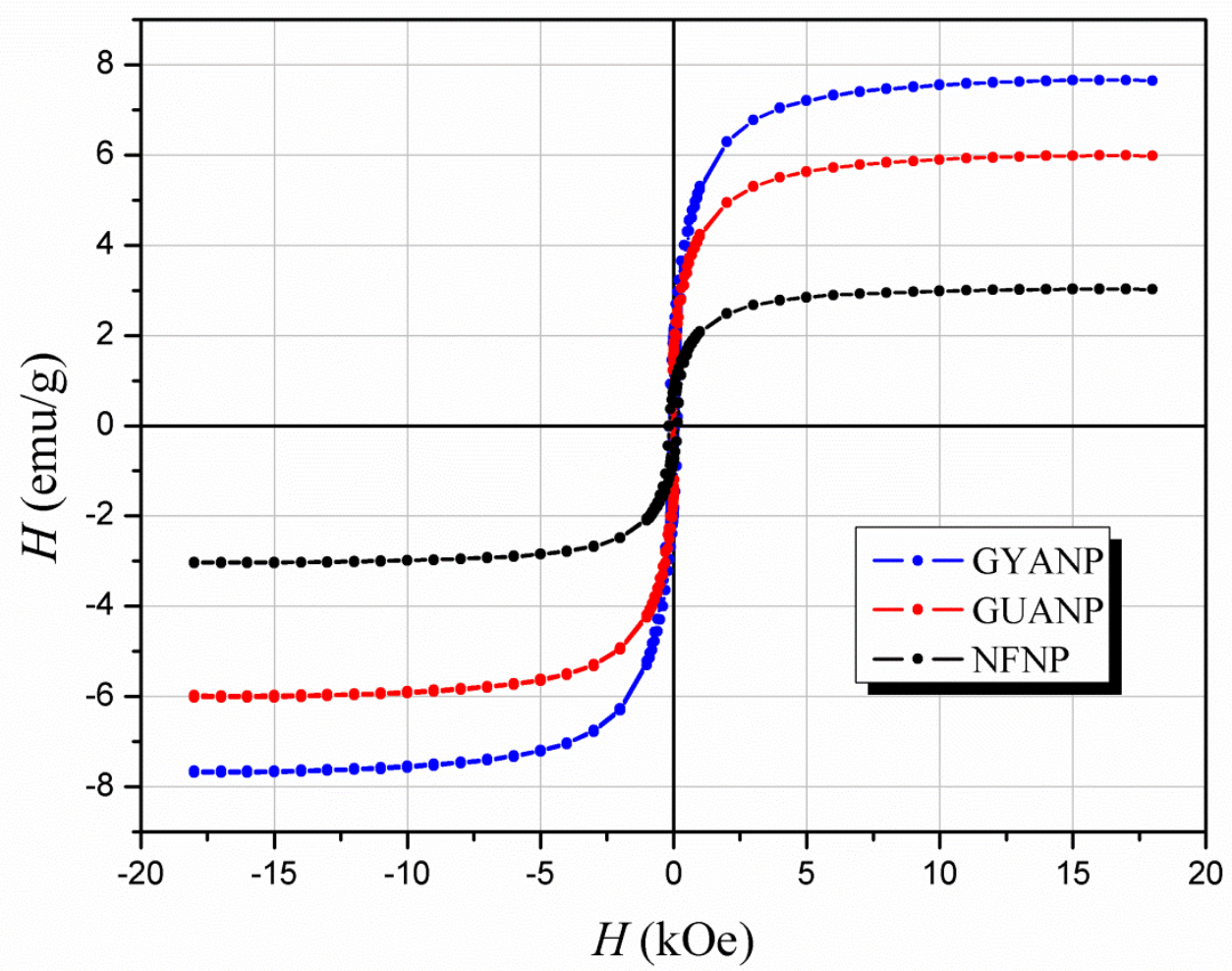

Figura 32 - Curvas de magnetização versus campo magnético aplicado para os FMs constituídos de NPs não funcionalizadas e funcionalizadas. 
Nesse caso, o comportamento das amostras é superparamagnético, uma vez que não há magnetização remanente e campo o coercitivo é nulo, indicando qualidade na estabilidade coloidal. Além disso, quando a magnetização é normalizada pela concentração determinada pelo método descrito na seção 4.4, há superposição das curvas, indicando pequena interação entre as nanopartículas e eficiência no método proposto para estimar a concentração, conforme mostrado na figura 33.

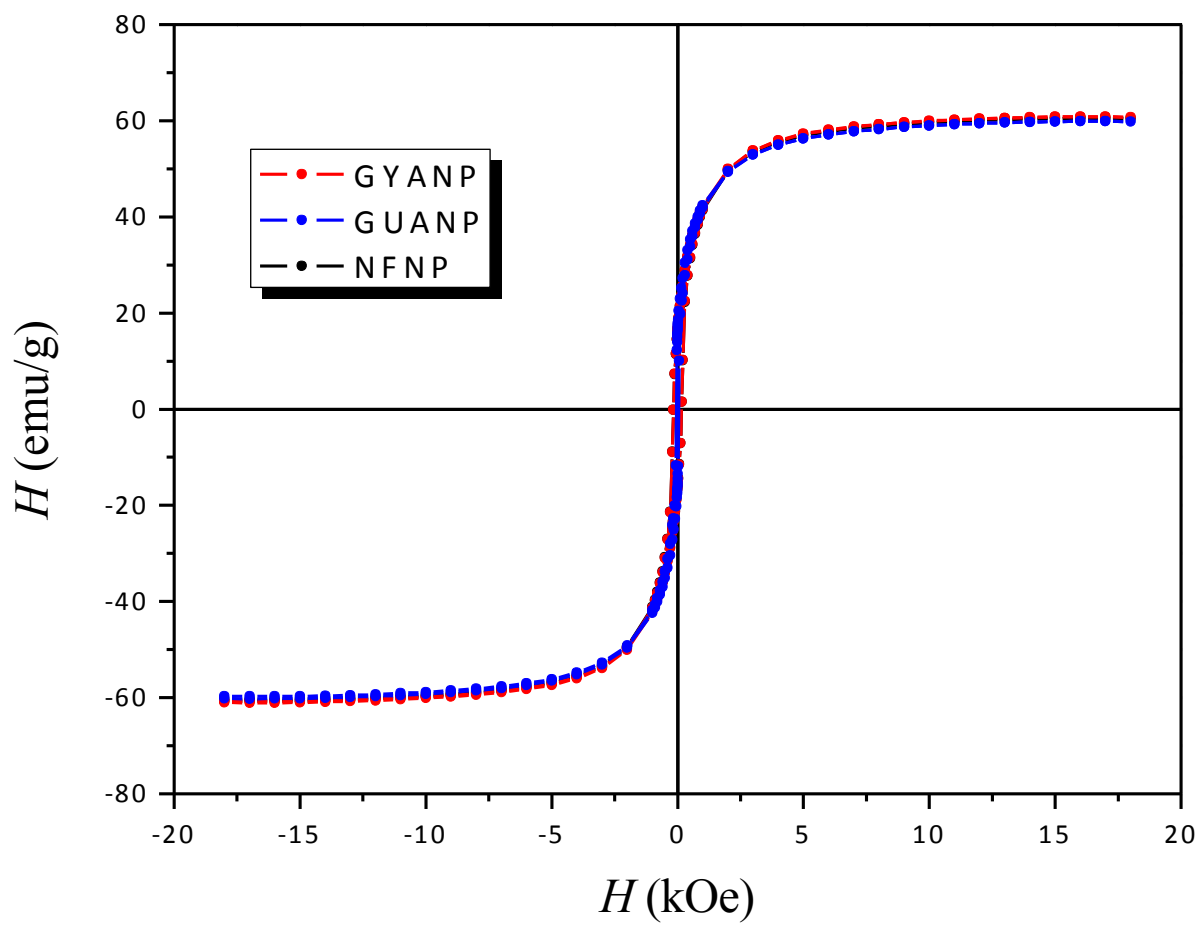

Figura 33 - Curvas de magnetização, normalizadas pela concentração do sol, para os FMs constituídos de NPs não funcionalizadas e funcionalizadas. 


\section{Conclusões e perspectivas}




\section{Conclusões e perspectivas}

A partir de um levantamento bibliográfico, notou-se a relevada importância do uso de nanomateriais magnéticos na área de nanobiotecnologia, em especial em biomedicina e bioremediação. Nessa direção, diversos nanossistemas, como é o caso de gliconanopartículas, que são NPs funcionalizadas com grupos hidroxílicos, são utilizados. Porém, apesar do elevado potencial de aplicação, principalmente devido à grande biocompatibilidade, poucos modelos de gliconanopartículas são propostos e usam, principalmente, polímeros hidroxilados como cobertura das NPs. Foi nesse âmbito que esse trabalho propôs a síntese e caracterização de NPMs funcionalizadas com ácidos carboxílicos polihidroxilados.

Para tal, nanopartículas de ferrita mista de cobalto e manganês, de composição $\mathrm{Mn}_{1-x} \mathrm{Co}_{x} \mathrm{Fe}_{2} \mathrm{O}_{4}$, determinada por ICP-OES foram sintetizadas por coprecipitação em meio alcalino. A estrutura cristalina do tipo espinélio foi identificada por DRX e, por meio do refinamento do difratograma obtido, que também comprovou outros parâmetros estruturais, um diâmetro de aproximadamente $17 \mathrm{~nm}$ foi calculado. A morfologia aproximadamente esférica, diâmetro médio de $\sim 15 \mathrm{~nm}$ e polidispersão de 0,35 foram averiguada por MET. A partir de um tratamento de superfície, foi possível dispersar essas NPMs em meio ácido, de maneira a se obter amostras estáveis e concentradas de FMs.

Parte da amostra foi funcionalizada com ácido glicérico e com ácido glucônico, utilizando-se os diagramas de especiação em função do pH das NPs e dos ligantes para otimizar a interação NP-ligante. Um excesso de ligante garantiu saturação da superfície das NPMs com moléculas dos ácidos e, por meio de FTIR e medidas de potencial eletrocinético, estabeleceu-se que essa ligação se dá via complexação da superfície das 
NPs com os grupos carboxilatos dos ácidos. Isso promoveu a modificação superficial, enriquecendo as NPs com grupamentos hidroxílicos, o que alterou o perfil de interação das mesmas com diversos solventes, entre eles, o glicerol, de maneira a gerar sois coloidais estáveis, mesmo em solventes menos indicados para peptização.

Considerando-se a dificuldade na determinação da concentração dos fluidos magnéticos, um modelo, com base em simples medidas de densidade, foi proposto e indicou grande precisão e facilidade de operação. Além disso, medidas de magnetização a $25^{\circ} \mathrm{C}$ mostraram as características magnéticas das amostras de NPMs e FMs e permitiram investigar acerca da estabilidade e ordem magnética das NPs.

Esse estudo mostrou grande potencialidade do sistema aqui proposto e algumas vantagens em relação a alguns similares, principalmente, devido ao fato que a grande maioria de gliconanopartículas magnéticas são constituídas de magnetita ou de maguemita e recobertas por polímeros de massas moleculares grandes. Ao contrário, esse trabalho propõe o uso de ferrita de cobalto e manganês, com propriedades magnéticas diferenciadas dos óxidos de ferro citados e o uso de moléculas de cadeia curta, que implica em menor volume ao sistema magnético.

Entretanto, ainda é necessário expandir a investigação em algumas direções para melhor propor aplicações para os nanomateriais aqui elaborados: uma análise magnética mais aprofundada deve ser feita para evidenciar as vantagens dessas NPMs; um estudo quantitativo deve ser proposto para melhor elucidar a interação NP-ligante-solvente; um estudo quantitativo acerca da estabilidade coloidal deve ser levado a cabo; testes biológicos devem ser feitos para verificar a nanotoxicidade desses materiais; uma comparação com gliconanopartículas existentes deve ser feita, para evidenciar as vantagens das nanoestruturas aqui preparadas. 


\section{Bibliografia}




\section{Bibliografia}

[1] J.D. Hood, M. Bednarski, R. Frausto, S. Guccione, R.A. Reisfeld, R. Xiang, D.A. Cheresh, Tumor regression by targeted gene delivery to the neovasculature, Science, 296 (2002) 2404-2407.

[2] S. Laurent, D. Forge, M. Port, A. Roch, C. Robic, L.V. Elst, R.N. Muller, Magnetic iron oxide nanoparticles: Synthesis, stabilization, vectorization, physicochemical characterizations, and biological applications, Chem Rev, 108 (2008) 2064-2110.

U. Jeong, X.W. Teng, Y. Wang, H. Yang, Y.N. Xia, Superparamagnetic colloids: Controlled synthesis and niche applications, Adv Mater, 19 (2007) 33-60.

A.H. Lu, E.L. Salabas, F. Schuth, Magnetic nanoparticles: Synthesis, protection, functionalization, and application, Angew Chem Int Edit, 46 (2007) 1222-1244.

Z. Cvejic, S. Rakic, A. Kremenovic, B. Antic, C. Jovalekic, P. Colomban, Nanosize ferrites obtained by ball milling: Crystal structure, cation distribution, size-strain analysis and Raman investigations, Solid State Sci, 8 (2006) 908-915.

T.J. Park, S. Sambasivan, D.A. Fischer, W.S. Yoon, J.A. Misewich, S.S. Wong, Electronic structure and chemistry of iron-based metal oxide nanostructured materials: A NEXAFS investigation of $\mathrm{BiFeO} 3$, Bi2Fe4O9, alpha-Fe2O3, gammaFe2O3, and Fe/Fe3O4, J Phys Chem C, 112 (2008) 10359-10369.

L.V. Gasparov, D.B. Tanner, D.B. Romero, H. Berger, G. Margaritondo, L. Forro, Infrared and Raman studies of the Verwey transition in magnetite, Phys Rev B, 62 (2000) 7939-7944.

D.H. Kim, H.J. Lee, G. Kim, Y.S. Koo, J.H. Jung, H.J. Shin, J.Y. Kim, J.S. Kang, Interface electronic structures of BaTiO3@X nanoparticles (X=gamma-Fe2O3, $\mathrm{Fe} 3 \mathrm{O} 4$, alpha-Fe2O3, and Fe) investigated by XAS and XMCD, Phys Rev B, 79 (2009).

A.D. Rowan, C.H. Patterson, L.V. Gasparov, Hybrid density functional theory applied to magnetite: Crystal structure, charge order, and phonons, Phys Rev B, 79 (2009).

W.F.J. Fontijn, P.J. vanderZaag, M.A.C. Devillers, V.A.M. Brabers, R. Metselaar, Optical and magneto-optical polar Kerr spectra of $\mathrm{Fe} 3 \mathrm{O} 4$ and $\mathrm{Mg} 2+-$ or Al3+substituted Fe3O4, Phys Rev B, 56 (1997) 5432-5442.

I. Chamritski, G. Burns, Infrared- and Raman-active phonons of magnetite, maghemite, and hematite: A computer simulation and spectroscopic study, J Phys Chem B, 109 (2005) 4965-4968.

H.T. Hai, H. Kura, M. Takahashi, T. Ogawa, Facile synthesis of Fe3O4 nanoparticles by reduction phase transformation from gamma-Fe2O3 nanoparticles in organic solvent, J Colloid Interf Sci, 341 (2010) 194-199. 
S.G. Kwon, Y. Piao, J. Park, S. Angappane, Y. Jo, N.M. Hwang, J.G. Park, T. Hyeon, Kinetics of monodisperse iron oxide nanocrystal formation by "heating-up" process, Journal of the American Chemical Society, 129 (2007) 12571-12584.

J. Tang, M. Myers, K.A. Bosnick, L.E. Brus, Magnetite Fe3O4 nanocrystals: Spectroscopic observation of aqueous oxidation kinetics, J Phys Chem B, 107 (2003) 7501-7506.

[3] E.V. Groman, J.C. Bouchard, C.P. Reinhardt, D.E. Vaccaro, Ultrasmall mixed ferrite colloids as multidimensional magnetic resonance imaging, cell labeling, and cell sorting agents, Bioconjugate Chem, 18 (2007) 1763-1771.

[4] N. C. Feitoza, T. D. Goncalves, J. J. Mesquita, J. S. Menegucci, M. K. M. S. Santos, J. A. Chaker, R. B. Cunha, A. M. M. Medeiros, J. C. Rubim, and M. H. Sousa, 'Fabrication of Glycine-Functionalized Maghemite Nanoparticles for Magnetic Removal of Copper from Wastewater', Journal of Hazardous Materials, 264 (2014), 153-60.

[5] B. Thiesen, and A. Jordan, 'Clinical Applications of Magnetic Nanoparticles for Hyperthermia', International Journal of Hyperthermia, 24 (2008), 467-74.

[6] J. Bao, W. Chen, T.T. Liu, Y.L. Zhu, P.Y. Jin, L.Y. Wang, J.F. Liu, Y.G. Wei, Y.D. $\mathrm{Li}$, Bifunctional Au-Fe3O4 nanopartides for protein separation, Acs Nano, 1 (2007) 293-298.

H.L. Liu, C.H. Sonn, J.H. Wu, K.M. Lee, Y.K. Kim, Synthesis of streptavidinFITC-conjugated core-shell Fe3O4-Au nanocrystals and their application for the purification of CD4(+) lymphocytes, Biomaterials, 29 (2008) 4003-4011.

[7] H.L. Liu, C.H. Sonn, J.H. Wu, K.M. Lee, Y.K. Kim, Synthesis of streptavidinFITC-conjugated core-shell $\mathrm{Fe} 3 \mathrm{O} 4-\mathrm{Au}$ nanocrystals and their application for the purification of CD4(+) lymphocytes, Biomaterials, 29 (2008) 4003-4011.

F.H. Chen, Q. Gao, J.Z. Ni, The grafting and release behavior of doxorubincin from $\mathrm{Fe}(3) \mathrm{O}(4) @ \mathrm{SiO}(2)$ core-shell structure nanoparticles via an acid cleaving amide bond: the potential for magnetic targeting drug delivery, Nanotechnology, 19 (2008).

W.Z. Li, J. Li, Z.M. Tan, Synthesis and Characterization of APTTS-Fe3O4 Nanoparticles for in vitro Transfection as Gene Carriers, Chem J Chinese U, 30 (2009) 2331-2336.

I. Sudakar, A. Dixit, R. Regmi, R. Naik, G. Lawes, V.M. Naik, P.P. Vaishnava, U. Toti, J. Panyam, Fe3O4 Incorporated AOT-Alginate Nanoparticles for Drug Delivery, Ieee T Magn, 44 (2008) 2800-2803.

Y.F. Zhu, T. Ikoma, N. Hanagata, S. Kaskel, Rattle-Type Fe3O4@SiO2 Hollow Mesoporous Spheres as Carriers for Drug Delivery, Small, 6 (2010) 471-478. 
[8] C. C. Berry, 'Progress in Functionalization of Magnetic Nanoparticles for Applications in Biomedicine', Journal of Physics D-Applied Physics, 42 (2009).

[9] F. Bitter, Experiments on the Nature of Ferromagnetism, Phys. Rev. 41 (1932) 507.

[10] L. W. McKeehan and W. C. Elmore, Surface Magnetization in Ferromagnetic Crystals, Phys. Rev., 46 (1934) 226.

[11] S. S. Pappell, U. S. Patent. 3, 215, 572 (1965)

[12] Rosensweig, R. Kaiser, Miskolcz.G, Viscosity of Magnetic Fluid in a Magnetic Field, J Colloid Interf Sci, 29 (1969) 680

[13] Khalafal.Se, G.W. Reimers, Separating Non-Ferrous Metals in Incinerator Residue Using Magnetic Fluids, Separ Sci, 8 (1973) 161-178.

[14] R. Massart, 'Preparation of Aqueous Magnetic Liquids in Alkaline and Acidic Media', Ieee Transactions on Magnetics, 17 (1981), 1247-48.

[15] B. Berkovsky, "Thermomechanics of Magnetic Fluids - Theory and Applications". Hemisphere Publishing Corporation, Washington (1977)

[16] J.G. King, W. Williams, C.D.W. Wilkinson, S. McVitie, J.N. Chapman, Magnetic properties of magnetite arrays produced by the method of electron beam lithography, Geophys Res Lett, 23 (1996) 2847-2850.

S.A. Rishton, Y. Lu, R.A. Altman, A.C. Marley, X.P. Bian, C. Jahnes, R. Viswanathan, G. Xiao, W.J. Gallagher, S.S.P. Parkin, Magnetic tunnel junctions fabricated at tenth-micron dimensions by electron beam lithography, Microelectron Eng, 35 (1997) 249-252.

C.S. Lee, H. Lee, R.M. Westervelt, Microelectromagnets for the control of magnetic nanoparticles, Appl Phys Lett, 79 (2001) 3308-3310.

S. Mathur, S. Barth, U. Werner, F. Hernandez-Ramirez, A. Romano-Rodriguez, Chemical vapor growth of one-dimensional magnetite nanostructures, Adv Mater, 20 (2008) 1550-+.

[17] R. Massart, Preparation of Aqueous Magnetic Liquids in Alkaline and Acidic Media, Ieee T Magn, 17 (1981) 1247-1248.

J.H. Wu, S.P. Ko, H.L. Liu, S. Kim, J.S. Ju, Y. Keun-Kim, Sub 5 nm magnetite nanoparticles: Synthesis, microstructure, and magnetic properties, Mater Lett, 61 (2007) 3124-3129.

[18] S. H. Sun, H. Zeng, D. B. Robinson, S. Raoux, P. M. Rice, S. X. Wang, and G. X. $\mathrm{Li}$, 'Monodisperse Mfe2o4 (M = Fe, Co, Mn) Nanoparticles', Journal of the American Chemical Society, 126 (2004), 273-79. 
[19] Y.B. Khollam, S.R. Dhage, H.S. Potdar, S.B. Deshpande, P.P. Bakare, S.D. Kulkarni, S.K. Date, Microwave hydrothermal preparation of submicron-sized spherical magnetite (Fe3O4)powders, Mater Lett, 56 (2002) 571-577.

F.H. Chen, Q. Gao, G.Y. Hong, J.Z. Ni, Synthesis and characterization of magnetite dodecahedron nanostructure by hydrothermal method, J Magn Magn Mater, 320 (2008) 1775-1780.

[20] G.M. Dacoata, E. Degrave, P.M.A. Debakker, R.E. Vandenberghe, Synthesis and Characterization of Some Iron-Oxides by Sol-Gel Method, J Solid State Chem, 113 (1994) 405-412.

H. Itoh, T. Sugimoto, Systematic control of size, shape, structure, and magnetic properties of uniform magnetite and maghemite particles, J Colloid Interf Sci, 265 (2003) 283-295.

[21] M. Breulmann, H. Colfen, H.P. Hentze, M. Antonietti, D. Walsh, S. Mann, Elastic magnets: Template-controlled mineralization of iron oxide colloids in a sponge-like gel matrix, Adv Mater, 10 (1998) 237-+.

[22] Y. Amemiya, A. Arakaki, S.S. Staniland, T. Tanaka, T. Matsunaga, Controlled formation of magnetite crystal by partial oxidation of ferrous hydroxide in the presence of recombinant magnetotactic bacterial protein Mms6, Biomaterials, 28 (2007) 5381-5389.

F. Vereda, B. Rodriguez-Gonzalez, J. de Vicente, R. Hidalgo-Alvarez, Evidence of direct crystal growth and presence of hollow microspheres in magnetite particles prepared by oxidation of $\mathrm{Fe}(\mathrm{OH})(2)$, J Colloid Interf Sci, 318 (2008) 520-524.

[23] G. Salazar-Alvarez, M. Muhammed, A.A. Zagorodni, Novel flow injection synthesis of iron oxide nanoparticles with narrow size distribution, Chem Eng Sci, 61 (2006) 4625-4633.

[24] L. Cabrera, S. Gutierrez, N. Menendez, M.P. Morales, P. Heffasti, Magnetite nanoparticles: Electrochemical synthesis and characterization, Electrochim Acta, 53 (2008) 3436-3441.

R.F.C. Marques, C. Garcia, P. Lecante, S.J.L. Ribeiro, L. Noe, N.J.O. Silva, V.S. Amaral, A. Millan, M. Verelst, Electro-precipitation of $\mathrm{Fe}(3) \mathrm{O}(4)$ nanoparticles in ethanol, J Magn Magn Mater, 320 (2008) 2311-2315.

[25] R. Strobel, S.E. Pratsinis, Direct synthesis of maghemite, magnetite and wustite nanoparticles by flame spray pyrolysis, Adv Powder Technol, 20 (2009) 190-194.

[26] N. Enomoto, J. Akagi, Z. Nakagawa, Sonochemical powder processing of iron hydroxides, Ultrason Sonochem, 3 (1996) S97-S103. 
F. Dang, N. Enomoto, J. Hojo, K. Enpuku, Sonochemical synthesis of monodispersed magnetite nanoparticles by using an ethanol-water mixed solvent, Ultrason Sonochem, 16 (2009) 649-654.

[27] C.A. Eckert, B.L. Knutson, P.G. Debenedetti, Supercritical fluids as solvents for chemical and materials processing, Nature, 383 (1996) 313-318.

U.T. Lam, R. Mammucari, K. Suzuki, N.R. Foster, Processing of iron oxide nanoparticles by supercritical fluids, Ind Eng Chem Res, 47 (2008) 599-614.

[28] A.K. Gupta, A.S.G. Curtis, Surface modified superparamagnetic nanoparticles for drug delivery: Interaction studies with human fibroblasts in culture, J Mater SciMater M, 15 (2004) 493-496.

D.L. Ma, J.W. Guan, F. Normandin, S. Denommee, G. Enright, T. Veres, B. Simard, Multifunctional nano-architecture for biomedical applications, Chem Mater, 18 (2006) 1920-1927.

S. Chen, Y. Li, C. Guo, J. Wang, J.H. Ma, X.F. Liang, L.R. Yang, H.Z. Liu, Temperature-responsive magnetite/PEO-PPO-PEO block copolymer nanoparticles for controlled drug targeting delivery, Langmuir, 23 (2007) 12669-12676.

M. De Cuyper, S.J.H. Soenen, K. Coenegrachts, L. Ter Beek, Surface functionalization of magnetoliposomes in view of improving iron oxide-based magnetic resonance imaging contrast agents: Anchoring of gadolinium ions to a lipophilic chelate, Anal Biochem, 367 (2007) 266-273.

H.B. Liu, J. Guo, L. Jin, W.L. Yang, C.C. Wang, Fabrication and functionalization of dendritic poly(amidoamine)-immobilized magnetic polymer composite microspheres, J Phys Chem B, 112 (2008) 3315-3321.

29 D. A. Bloss, "Crystallography and Crystal Chemistry - an Introduction". Rinehart and Winston Inc. New York (1971)

[30] K. Krieble, T. Schaeffer, J.A. Paulsen, A.P. Ring, C.C.H. Lo, J.E. Snyder, Mossbauer spectroscopy investigation of mn-substituted co-ferrite (CoMnxFe2xO4), J Appl Phys, 97 (2005).

[31] C.S. Kim, Y.S. Yi, K.T. Park, H. Namgung, J.G. Lee, Growth of ultrafine Co-Mn ferrite and magnetic properties by a sol-gel method, J Appl Phys, 85 (1999) 52235225 .

[32] M.K. Shobana, S. Sankar, V. Rajendran, Characterization of Co0.5Mn0.5Fe2O4 nanoparticles, Mater Chem Phys, 113 (2009) 10-13.

[33] T. D. Rao, T. Karthik, and S. Asthana, 'Investigation of Structural, Magnetic and Optical Properties of Rare Earth Substituted Bismuth Ferrite', Journal of Rare Earths, 31 (2013), 370-75. 
[34] R. M. Cornell, U. Schwertmann, The Iron Oxides, John Wiley \& Sons, New York (1997)

[35] R.H. Kodama, Magnetic nanoparticles, J Magn Magn Mater, 200 (1999) 359-372.

[36] J. L. Dormann, D. Fiorani, Magnetic Properties of Fine Particles, North-Holland, Amsterdam (1992)

[37] J.C. Bacri, R. Perzynski, D. Salin, V. Cabuil, R. Massart, Magnetic Colloidal Properties of Ionic Ferrofluids, J Magn Magn Mater, 62 (1986) 36-46.

[38] J. F. B. Santana, M. A. G. Soler, S. W. da Silva, M. H. Guedes, Z. G. M. Lacava, R. B. Azevedo, and P. C. Morais, 'Investigation of the Interaction between Magnetic Nanoparticles Surface-Coated with Carboxymethyldextran and Blood Cells Using Raman Spectroscopy', Journal of Magnetism and Magnetic Materials, 289 (2005), 452-54.

[39] N. Fauconnier, A. Bee, J. Roger, and J. N. Pons, 'Synthesis of Aqueous Magnetic Liquids by Surface Complexation of Maghemite Nanoparticles', Journal of Molecular Liquids, 83 (1999), 233-42.

[40] X.H. Sun, C.M. Zheng, F.X. Zhang, Y.L. Yang, G.J. Wu, A.M. Yu, N.J. Guan, Size-Controlled Synthesis of Magnetite (Fe3O4) Nanoparticles Coated with Glucose and Gluconic Acid from a Single Fe(III) Precursor by a Sucrose Bifunctional Hydrothermal Method, J Phys Chem C, 113 (2009) 16002-16008.

[41] V. Kekkonen, N. Lafreniere, M. Ebara, A. Saito, Y. Sawa, R. Narain, Synthesis and characterization of biocompatible magnetic glyconanoparticles, J Magn Magn Mater, 321 (2009) 1393-1396.

[42] X.C. Wei, Z.W. Wei, L.P. Zhang, Y.Q. Liu, D.Y. He, Highly water-soluble nanocrystal powders of magnetite and maghemite coated with gluconic acid: Preparation, structure characterization, and surface coordination, J Colloid Interf Sci, 354 (2011) 76-81.

[43] Y. Sui, Y. Cui, Y. Nie, G.M. Xia, G.X. Sun, J.T. Han, Surface modification of magnetite nanoparticles using gluconic acid and their application in immobilized lipase, Colloid Surface B, 93 (2012) 24-28.

[44] C. E. Hall, "Introduction to Eletron Microscopy". McGraw-Hill Book Company Inc., New York (1953)

[45] B. D. Cullity, "Elements of X-Ray Diffraction". Addison-Wesley Publishing Company Inc., Massachusetts (1978)

[46] C. Giacovazzo, H.L. Monaco, D. Viterbo, F. Scarderi, G. Gilli, G. Zanotti and M. Catti. "Fundamentals of Crystallography". Edited by C. Giacovazzo, International Union of Crystallography (IUCr), Oxford Science Publications. 
[47] J.A. Gomes, M.H. Sousa, F.A. Tourinho, J. Mestnik, R. Itri, J. Depeyrot, Rietveld structure refinement of the cation distribution in ferrite fine particles studied by Xray powder diffraction, J Magn Magn Mater, 289 (2005) 184-187.

[48] M. H. Sousa, G. J. da Silva, J. Depeyrot, F. A. Tourinho, and L. F. Zara, 'Chemical Analysis of Size-Tailored Magnetic Colloids Using Slurry Nebulization in Icp-Oes', Microchemical Journal, 97 (2011), 182-87.

[49] S. Foner, The vibrating sample magnetometer: Experiences of a volunteer, J Appl Phys, 79 (1996) 4740-4745.

[50] M. H. Sousa, F. A. Tonrinho, J. Depeyrot, G. J. da Silva, and M. C. F. L. Lara, 'New Electric Double-Layered Magnetic Fluids Based on Copper, Nickel, and Zinc Ferrite Nanostructures', Journal of Physical Chemistry B, 105 (2001), 1168-75.

[51] F.A. Tourinho, A.F.C. Campos, R. Aquino, M.C.F.L. Lara, G.J. da Silva, J. Depeyrot, Surface charge density determination in electric double layered magnetic fluids, Braz J Phys, 32 (2002) 501-508.

[52] J. D. Gomes, M. H. Sousa, F. A. Tourinho, R. Aquino, G. J. da Silva, J. Depeyrot, E. Dubois, and R. Perzynski, 'Synthesis of Core-Shell Ferrite Nanoparticles for Ferrofluids: Chemical and Magnetic Analysis', Journal of Physical Chemistry C, 112 (2008), 6220-27.

[53] P.D. Thang, G. Rijnders, D.H.A. Blank, Spinel cobalt ferrite by complexometric synthesis, J Magn Magn Mater, 295 (2005) 251-256.

[54] R. Massart, E. Dubois, V. Cabuil, and E. Hasmonay, 'Preparation and Properties of Monodisperse Magnetic Fluids', Journal of Magnetism and Magnetic Materials, 149 (1995), 1-5.

[55] C. Pereira, A.M. Pereira, C. Fernandes, M. Rocha, R. Mendes, M.P. FernandezGarcia, A. Guedes, P.B. Tavares, J.M. Greneche, J.P. Araujo, C. Freire, Superparamagnetic MFe2O4 ( $\mathrm{M}=\mathrm{Fe}, \mathrm{Co}, \mathrm{Mn})$ Nanoparticles: Tuning the Particle Size and Magnetic Properties through a Novel One-Step Coprecipitation Route, Chem Mater, 24 (2012) 1496-1504.

[56] L.V. Gasparov, D.B. Tanner, D.B. Romero, H. Berger, G. Margaritondo, L. Forro, Infrared and Raman studies of the Verwey transition in magnetite, Phys Rev B, 62 (2000) 7939-7944.

[57] M.H. Sousa, F.A. Tourinho, J.C. Rubim, Use of Raman micro-spectroscopy in the characterization of $\mathrm{M}(\mathrm{II}) \mathrm{Fe} 2 \mathrm{O} 4(\mathrm{M}=\mathrm{Fe}, \mathrm{Zn})$ electric double layer ferrofluids, J Raman Spectrosc, 31 (2000) 185-191.

[58] G.V.M. Jacintho, A.G. Brolo, P. Corio, P.A.Z. Suarez, J.C. Rubim, Structural Investigation of MFe2O4 ( $\mathrm{M}=\mathrm{Fe}, \mathrm{Co})$ Magnetic Fluids, J Phys Chem C, 113 (2009) 7684-7691. 
[59] J.C. Rubim, M.H. Sousa, J.C.O. Silva, F.A. Tourinho, Raman spectroscopy as a powerful technique in the characterization of ferrofluids, Braz J Phys, 31 (2001) 402-408.

[60] R. Aquino, J. Depeyrot, M. H. Sousa, F. A. Tourinho, E. Dubois, and R. Perzynski, 'Magnetization Temperature Dependence and Freezing of Surface Spins in Magnetic Fluids Based on Ferrite Nanoparticles', Physical Review B, 72 (2005).

[61] J.A. Gomes, M.H. Sousa, F.A. Tourinho, J. Mestnik, R. Itri, J. Depeyrot, Rietveld structure refinement of the cation distribution in ferrite fine particles studied by Xray powder diffraction, J Magn Magn Mater, 289 (2005) 184-187.

[62] E.C. Sousa, M.H. Sousa, G.F. Goya, H.R. Rechenberg, M.C.F.L. Lara, F.A. Tourinho, J. Depeyrot, Enhanced surface anisotropy evidenced by Mossbauer spectroscopy in nickel ferrite nanoparticles, J Magn Magn Mater, 272 (2004) E1215-E1217.

[63] J.F. Saenger, K.S. Neto, P.C. Morais, M.H. Sousa, F.A. Tourinho, Investigation of the anisotropy in frozen nickel ferrite ionic magnetic fluid using magnetic resonance, J Magn Reson, 134 (1998) 180-183. 